\title{
Recent Advancements in Polyphenylsulfone Membrane Modification Methods for Separation Applications
}

\author{
Arun Kumar Shukla ${ }^{1}$ (D) Javed Alam ${ }^{1, *(\mathbb{D})}$ and Mansour Alhoshan 1,2,3,* \\ 1 King Abdullah Institute for Nanotechnology, King Saud University, P.O. Box 2455, \\ Riyadh 11451, Saudi Arabia; ashukla@ksu.edu.sa \\ 2 Department of Chemical Engineering, College of Engineering, King Saud University, P.O. Box 2455, \\ Riyadh 11451, Saudi Arabia \\ 3 K.A. CARE Energy Research and Innovation Center at Riyadh, P.O. Box 2022, Riyadh 11451, Saudi Arabia \\ * Correspondence: javaalam@ksu.edu.sa (J.A.); mhoshan@ksu.edu.sa (M.A.)
}

check for updates

Citation: Shukla, A.K.; Alam, J.; Alhoshan, M. Recent Advancements in Polyphenylsulfone Membrane Modification Methods for Separation Applications. Membranes 2022, 12, 247. https://doi.org/10.3390/ membranes12020247

Academic Editor: Jaewon Jang

Received: 26 January 2022

Accepted: 17 February 2022

Published: 21 February 2022

Publisher's Note: MDPI stays neutral with regard to jurisdictional claims in published maps and institutional affiliations.

Copyright: (C) 2022 by the authors. Licensee MDPI, Basel, Switzerland. This article is an open access article distributed under the terms and conditions of the Creative Commons Attribution (CC BY) license (https:// creativecommons.org/licenses/by/ $4.0 /)$.

\begin{abstract}
Polyphenylsulfone (PPSU) membranes are of fundamental importance for many applications such as water treatment, gas separation, energy, electronics, and biomedicine, due to their low cost, controlled crystallinity, chemical, thermal, and mechanical stability. Numerous research studies have shown that modifying surface properties of PPSU membranes influences their stability and functionality. Therefore, the modification of the PPSU membrane surface is a pressing issue for both research and industrial communities. In this review, various surface modification methods and processes along with their mechanisms and performance are considered starting from 2002. There are three main approaches to the modification of PPSU membranes. The first one is bulk modifications, and it includes functional groups inclusion via sulfonation, amination, and chloromethylation. The second is blending with polymer (for instance, blending nanomaterials and biopolymers). Finally, the third one deals with physical and chemical surface modifications. Obviously, each method has its own limitations and advantages that are outlined below. Generally speaking, modified PPSU membranes demonstrate improved physical and chemical properties and enhanced performance. The advancements in PPSU modification have opened the door for the advance of membrane technology and multiple prospective applications.
\end{abstract}

Keywords: membranes; modification methods; polyphenylsulfone; separation

\section{Introduction}

Polyphenylsulfone (PPSU) belongs to sulfone-family polymers that have been thoroughly studied for their potential applications in membrane science and technology. The state-of-the-art PPSU-based membranes show superior properties, including excellent thermal and mechanical stability, high chemical resistance, impact resistance, and hydrolytic stability [1-8]. This stability can be attributed to the difference in their backbone structure compared to other polymeric materials. However, the membrane morphological structure and properties are elaborated by the composition and operating conditions of a PPSU solution, including concentration, additives, solvent type, temperature, kinetic factors, the coagulation bath (phase inversion process), etc. [9-16]. Thermodynamics and kinetics play significant roles during membrane development [17-19]. Thermodynamics determines whether a PPSU polymer solution is stable or not. Kinetics plays a key role in the phase separation speed. Despite the aforementioned important properties of PPSU polymers, there has been a limited number of studies concerning the preparation of PPSU membranes [20-23]. However, these studies showed promising results in polymer applications. In particular, the membranes can be used for ultrafiltration, nanofiltration, and reverse and forward osmosis. At the same time, other polymer materials often prove more susceptible in terms of stability (chemical, thermal, and mechanical) and are often expensive [24-30]. 
One disadvantage of PPSU-based membranes is their hydrophobic nature, which leads to reduced surface energy. The latter causes poor antifouling ability by foulant pollutants in water. Two more disadvantages of the PPSU membrane are its low water permeability and high fouling ability. These two have limited its application in aqueous phase separation. A number of studies have concluded that membrane fouling is directly related to hydrophobicity and surface charge, as reviewed by several researchers, while the opposite has also been reported [31-34]. Membrane fouling is generally classified as organic fouling, inorganic fouling, or biofouling (nonpolar solutes, hydrophobic particles, microorganism, mineral scale). It can easily adhere to or accumulate on the membrane surface or plug membrane pores by hydrophobic interactions, hydrogen bonding, van der Waals attractions, and electrostatic interactions [14,35-39]. As a result, the membrane separation process becomes more complex, and its permeability and selectivity are reduced. The latter leads to an increase in operating costs, energy demand, and shorter membrane lifetimes.

Thus, the current trend is to improve PPSU membrane materials and structures and to get membranes with both good separation and antifouling performance. Controlling the membrane surface properties and structure has been a common goal for improving membrane separation performance (Figure 1). Achieving this goal is not an easy task. However, various types of inorganic and organic materials have been used to improve the characteristics of the PPSU membranes [28,40-43]. Several features, including the PPSU and additive concentrations, molecular weights, the miscibility characteristics, the compatibility with organic and inorganic materials properties, and the solvent type, can impact the performance of these additives.

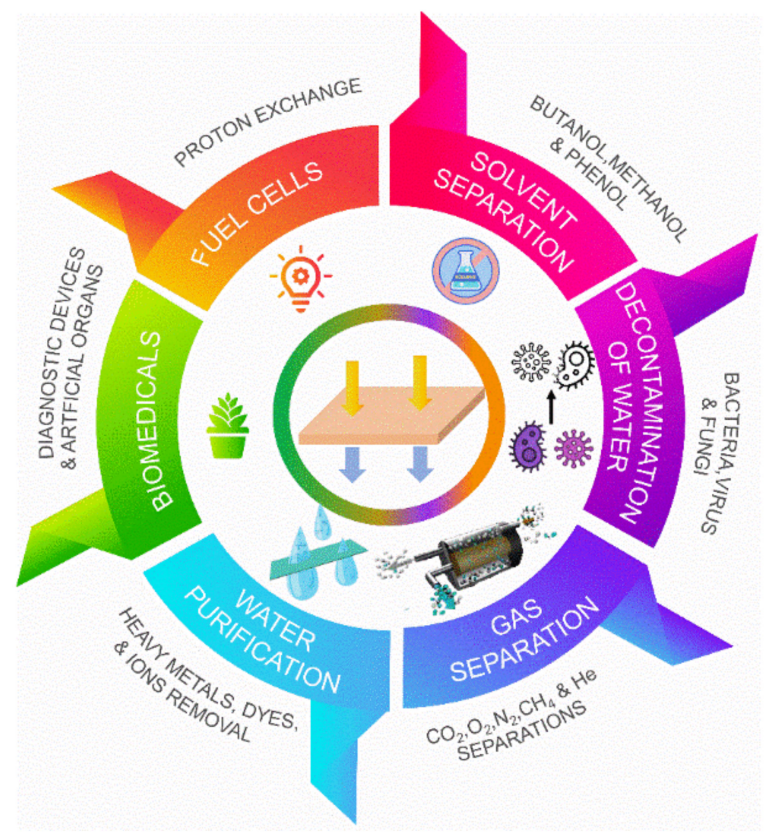

Figure 1. PPSU membranes significant environmental applications: water purification, gas separation, decontamination of water, solvent separation, fuel cell, and biomedical.

Multiple studies have reported the fabrication of PPSU-based membranes in different configurations, including flat sheet and hollow fibers [44-48]. However, to the best of our knowledge, there is no state-of-the-art report on PPSU-based membranes that summarizes their surface modifications and associated changes in performance. The current review serves to fill this research gap. More specifically, we bring together recent advancements in polymer and membrane development for the benefit of both academic and industrial researchers. We focus on various modification methods as well as performance evaluation. There are three main approaches for the modification of PPSU polymer or membranes with improved surface properties: (1) bulk modifications via sulfonation, amination, and 
chloromethylation; (2) blending with a synthetic polymer, inorganic nanomaterials, and biopolymer; and (3) surface modification via physical and chemical approaches (Figure 2).

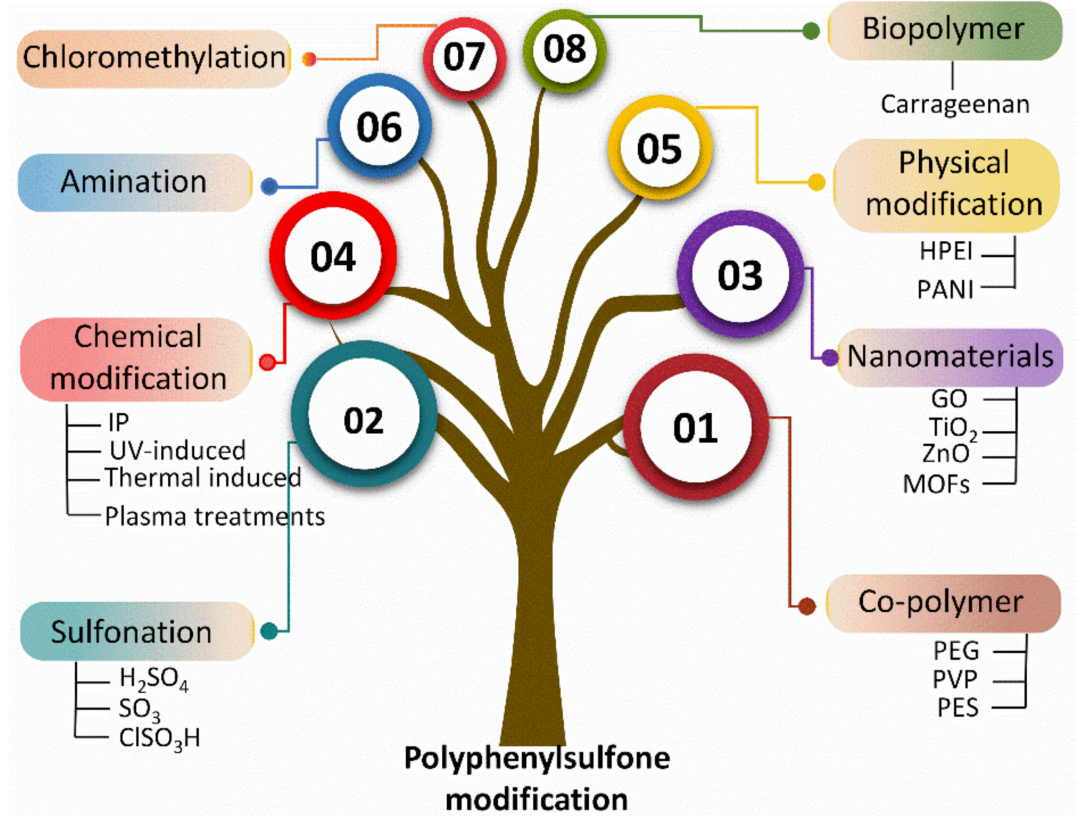

Figure 2. Modification techniques for PPSU utilizing various modifiers.

\section{Polyphenylsulfone Characteristics}

PPSU is the abbreviation for Polyphenylsulfone. Also known as PPSF, PPSU is a new member of the sulfone polymers family that has multiple attractive properties such as hightemperature performance, good chemical resistance (maintaining its original properties after being exposed to a harsh chemical environment $\mathrm{pH}$ at 1-13), outstanding toughness, corrosion resistance, chlorine tolerance, excellent colorability, and very good dimensional stability [49]. The polymer can be distributed in two different families depending on the level of the molecular organization of the constitutive chains at the microscopic level. Compared to other sulfone polymers, PPSU is an amorphous polymer. Therefore, it features very good creep resistance, isotropic thermal and mechanical properties, and transparency. PPSU consists of an aromatic unit (phenylene) chain with a sulfone group and a benzene ring, connected by an oxygen atom. Due to this conjugated structure, the rigidity of the material can be maintained, and it gives good liquidity [28,50]. Figure 3 shows the molecular structures of PPSU.

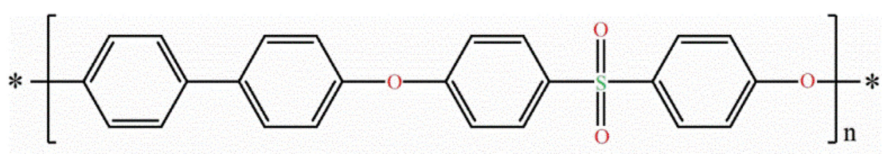

Figure 3. General structure of Polyphenylsulfone polymer.

The presence of the electronegative sulfone group results in sulfur being in its highest oxidation state. The latter brings excellent thermo-oxidative stability and easy functionalization. The surface of PPSU resin has a negative charge over a $\mathrm{pH}$ of 3 [30]. The existence of a biphenylene unit in PPSU resin significantly elevates the impact strength and reduces the notch sensitivity of the material. The latter results in strength at break (tensile) values greater than $75 \mathrm{MPa}$, a glass transition temperature of $288^{\circ} \mathrm{C}$, and a heat deflection temperature of $274{ }^{\circ} \mathrm{C}$. Therefore, PPSU is expected to become the next widely used polymer in various applications, including membrane filtration, plumbing, food services, medical, aerospace, wire and cable, etc. On the other hand, the PPSU-based membranes that have been widely used in water applications have several drawbacks. The main drawback is 
related to its relatively hydrophobic nature. It reduces membranes' permeability and makes them more susceptible to fouling during water treatment. Chemical cleaning is an essential step to sustain the membrane life. At the same time, high standards of water quality should also be met. Table 1 summarizes different methods that were used in the modification of PPSU membrane, modifier agents, and performance of modified membranes.

Table 1. Summary of frequently used methods for modification of PPSU membrane and performance.

\begin{tabular}{|c|c|c|c|c|c|c|}
\hline Description & $\begin{array}{l}\text { Methods of } \\
\text { Modification }\end{array}$ & Modifier Agents & $\begin{array}{l}\text { Process of } \\
\text { Membrane }\end{array}$ & Application & Performance & Ref. \\
\hline $\begin{array}{l}\text { Proton- } \\
\text { conductive } \\
\text { sPPSU } \\
\text { membranes }\end{array}$ & Sulfonation & $\begin{array}{l}\mathrm{SO}_{3} \text { and }\left(\mathrm{CH}_{3}\right)_{3} \\
\mathrm{SiSO}_{3} \mathrm{Cl}\end{array}$ & $\begin{array}{c}\text { Solvent } \\
\text { evaporation }\end{array}$ & Electrochemical & $\begin{array}{l}(\mathrm{CH} 3)_{3} \mathrm{SiClSO}_{3} \text { gave a } \\
\text { homogeneous sPPSU with } \\
\text { better control of the DS } \\
\text { values as high as } 1.0 ; \\
\text { asymmetric structure; high } \\
\text { mechanical stability; proton } \\
\text { conductivity about } \\
55 \mathrm{mS} / \mathrm{cm} \text { at } 80^{\circ} \mathrm{C}\end{array}$ & [51] \\
\hline $\begin{array}{l}\text { Proton- } \\
\text { conducting fuel } \\
\text { cell sphPPSU } \\
\text { membranes }\end{array}$ & Sulfophenylation & $\begin{array}{l}\text { BuLi (metalating } \\
\text { agent) and } \\
\text { 2-sulfobenzoic acid } \\
\text { cyclic anhydride }\end{array}$ & Vacuum dry & Fuel cells & $\begin{array}{l}\text { sphPPSU showed DS values } \\
\text { as } 0.9 ; \text { membranes have } \\
\text { high thermal stability }(300 \\
\left.\text { and } 350{ }^{\circ} \mathrm{C}\right) \text {; the proton } \\
\text { conductivity about } \\
60 \mathrm{mS} / \mathrm{cm} \text { at } 70^{\circ} \mathrm{C}\end{array}$ & [52] \\
\hline PEI/PPSU sheet & Blending & PEI & $\begin{array}{l}\text { Direct } \\
\text { injection } \\
\text { molding }\end{array}$ & Plasticization & $\begin{array}{l}\text { PEI/PPSU blends are } \\
\text { miscible; elasticity and yield } \\
\text { stress changed linearly with } \\
\text { PEI-rich blends composition }\end{array}$ & [53] \\
\hline $\begin{array}{c}\text { Proton exchange } \\
\text { SPEEK/SiSPPSU } \\
\text { membranes }\end{array}$ & $\begin{array}{l}\text { Silylation and } \\
\text { sulfonation; and } \\
\text { blending }\end{array}$ & $\begin{array}{l}\mathrm{PhSiCl}_{3} \text { and } \mathrm{H}_{2} \mathrm{SO}_{4} \\
\text { SPEEK }\end{array}$ & $\begin{array}{c}\text { Solvent } \\
\text { evaporation }\end{array}$ & Fuel cells & $\begin{array}{l}\text { SiSPPSU showed DS values } \\
\text { as } 2.0 \text {; exhibited high and } \\
\text { stable conductivity values at } \\
120^{\circ} \mathrm{C} \text { when dry } \\
\left(6.1 \times 10^{-3} \mathrm{~S} / \mathrm{cm}\right) \text { and wet } \\
\text { conditions } \\
\left(6.4 \times 10^{-2} \mathrm{~S} / \mathrm{cm}\right)\end{array}$ & [54] \\
\hline $\begin{array}{l}\text { sPPSU-proton } \\
\text { conducting } \\
\text { membrane }\end{array}$ & Sulfonation & $\begin{array}{l}\mathrm{H}_{2} \mathrm{SO}_{4} \text { and } \mathrm{ClSO}_{3} \mathrm{Si} \\
\qquad\left(\mathrm{CH}_{3}\right)_{3}\end{array}$ & $\begin{array}{l}\text { Sol-gel } \\
\text { processes }\end{array}$ & Fuel cells & $\begin{array}{c}\text { sPPSU reached the } \\
\text { conductivity values as high } \\
\text { as } 1.1 \times 10^{-2} \mathrm{~S} \mathrm{~cm}^{-1} \text { at } \\
130^{\circ} \mathrm{C}\end{array}$ & [55] \\
\hline $\begin{array}{l}\text { PPSU/PBNPI } \\
\text { membrane }\end{array}$ & Blending & PBNPI & $\begin{array}{c}\text { Solvent } \\
\text { evaporation }\end{array}$ & $\begin{array}{l}\text { Hydrogen } \\
\text { separation }\end{array}$ & $\begin{array}{l}\text { The gases } \mathrm{H}_{2}, \mathrm{CO}_{2} \text { and } \mathrm{CH}_{4} \\
\text { permeability increased up } \\
\text { to } 50 \%\end{array}$ & [56] \\
\hline $\begin{array}{l}\text { PPSU/PBNPI } \\
\text { membrane }\end{array}$ & $\begin{array}{l}\text { Blending; } \\
\text { immersion } \\
\text { method }\end{array}$ & $\begin{array}{c}\text { PBNPI; } \\
\text { p-xylylenediamine } \\
\text { (crosslinking reagent) }\end{array}$ & $\begin{array}{c}\text { Solvent } \\
\text { evaporation }\end{array}$ & Gas permeation & $\begin{array}{c}\mathrm{O}_{2} \text { and } \mathrm{N}_{2} \text { permeation rates } \\
\text { of } 23.2 \text { and } 22.42\end{array}$ & [57] \\
\hline $\begin{array}{l}\text { sPOSS/sPPSU } \\
\text { composite proton } \\
\text { exchange } \\
\text { membranes }\end{array}$ & Blending & sPOSS & Dry & Fuel cells & $\begin{array}{l}\text { sPOSS/sPPSU composites } \\
\text { multilayered structure and } \\
\text { reduce brittleness; } \\
\text { conductivity } 1 \times 10^{-2} \\
\mathrm{~S} \mathrm{~cm}^{-1} \text { at } 90^{\circ} \mathrm{C}\end{array}$ & [1] \\
\hline $\begin{array}{l}\text { Ionic exchange } \\
\text { sPPSU/sPES } \\
\text { membrane }\end{array}$ & $\begin{array}{l}\text { Sulfonation; } \\
\text { Blending }\end{array}$ & $\mathrm{H}_{2} \mathrm{SO}_{4} ; \mathrm{sPES}$ & $\begin{array}{l}\text { Solvent } \\
\text { evaporation } \\
\text { and dry }\end{array}$ & Fuel cells & $\begin{array}{c}\text { The membrane surfaces } \\
\text { show the smoother about } \\
2 \mathrm{~nm} \text {; stress-strain values } \\
80 \mathrm{MPa} \text { and } 7 \%\end{array}$ & [5] \\
\hline $\begin{array}{l}\text { SPEEK/SiPPSU } \\
\text { composite } \\
\text { membranes }\end{array}$ & $\begin{array}{l}\text { Silylation; } \\
\text { Blending }\end{array}$ & SPEEK & Dry & Fuel cells & $\begin{array}{l}\text { The presence of silicon } \\
\text { enhances the temperature of } \\
\text { loss of sulfonic acid groups; } \\
\text { composites show superior } \\
\text { behavior in terms of } \\
\text { mechanical properties } \\
\text { (higher elastic modulus and } \\
\text { tensile strength) }\end{array}$ & [50] \\
\hline
\end{tabular}


Table 1. Cont.

\begin{tabular}{|c|c|c|c|c|c|c|}
\hline Description & $\begin{array}{l}\text { Methods of } \\
\text { Modification }\end{array}$ & Modifier Agents & $\begin{array}{l}\text { Process of } \\
\text { Membrane }\end{array}$ & Application & Performance & Ref. \\
\hline $\begin{array}{l}\text { PPSU / PEI } \\
\text { membranes }\end{array}$ & Blending & PEI; PEG 200 & $\begin{array}{l}\text { Wet phase } \\
\text { inversion }\end{array}$ & Ultrafiltration & $\begin{array}{l}\text { Asymmetric and spongelike } \\
\text { structure; water contact } \\
\text { angle decreases significantly } \\
\text { upto } 64^{\circ} \text { and EWC } 59.37 \% \text {; } \\
\text { IEP shifted pH } 8 \text { and shown } \\
\text { positive charge; flux } 545.54 \\
\mathrm{~kg} \mathrm{~m}^{-2} \mathrm{~h}^{-1} \text {; rejection } 56 \%\end{array}$ & [20] \\
\hline $\begin{array}{l}\text { sPPSU positively } \\
\text { charged } \\
\text { membrane }\end{array}$ & UV grafting & $\begin{array}{l}\text { [2-(methacryloyloxy) } \\
\text { ethyl]trimethyl } \\
\text { ammonium chloride; } \\
\text { diallyldimethylam- } \\
\text { monium } \\
\text { chloride }\end{array}$ & & $\begin{array}{l}\text { Nanofiltration; } \\
\text { textile dyes }\end{array}$ & $\begin{array}{c}\text { Spongelike morphology; } \\
\text { MWCO 1627-1674 Da; PWP } \\
\text { of 9-14 } \mathrm{LMH} \mathrm{bar}^{-1} ; \\
\text { rejection of } \mathrm{MgCl}_{2}(95 \%) \\
\text { and Safranin } \mathrm{O} \text { dye }(99.9 \%)\end{array}$ & {$[58]$} \\
\hline $\begin{array}{l}\text { PPSU thin-film } \\
\text { composite } \\
\text { membrane }\end{array}$ & $\begin{array}{l}\text { Oxygen plasma } \\
\text { (pretreatment); } \\
\text { surface } \\
\text { modification }\end{array}$ & $\begin{array}{c}\text { 2,5-bis(4-amino-2- } \\
\text { trifluoromethyl- } \\
\text { phenoxy) } \\
\text { benzenesulfonic acid; } \\
\text { 4,4-bis(4-amino-2- } \\
\text { trifluoromethyl- } \\
\text { phenoxy)biphenyl- } \\
\text { 4,4-disulfonic } \\
\text { acid }\end{array}$ & $\begin{array}{l}\text { interfacial } \\
\text { polymeriza- } \\
\text { tion }\end{array}$ & $\begin{array}{l}\text { Nanofiltration; } \\
\text { dye removal }\end{array}$ & $\begin{array}{c}\text { Water flux } 63.9 \text { and } \\
71.3 \mathrm{~L} / \mathrm{m}^{2} \mathrm{~h} \text {; dye rejection } \\
48-80 \%\end{array}$ & [59] \\
\hline $\begin{array}{l}\text { sPPSU/sPES } \\
\text { membranes }\end{array}$ & $\begin{array}{l}\text { Sulfonation; } \\
\text { Blending }\end{array}$ & $\mathrm{H}_{2} \mathrm{SO}_{4} ; \mathrm{sPES}$ & $\begin{array}{l}\text { Crosslinking; } \\
\text { heat and dry }\end{array}$ & Fuel cells & $\begin{array}{l}\text { Maximum conductivity of } \\
0.12 \mathrm{~S} / \mathrm{cm}\end{array}$ & {$[60]$} \\
\hline $\begin{array}{l}\text { sPPSU TFC } \\
\text { membranes }\end{array}$ & $\begin{array}{l}\text { Surface } \\
\text { modification }\end{array}$ & MPD;TMC & $\begin{array}{l}\text { Interfacial } \\
\text { polymeriza- } \\
\text { tion }\end{array}$ & Forward osmosis & $\begin{array}{l}\text { Water flux up to } 54 \mathrm{LMH} \\
\text { with } 8.8 \mathrm{gMH} \text { salt reverse } \\
\text { flux under PRO mode }\end{array}$ & {$[61]$} \\
\hline $\begin{array}{l}\text { PPSU } / \text { PI solvent } \\
\text { resistant } \\
\text { membrane }\end{array}$ & Blending & PI & $\begin{array}{l}\text { Phase } \\
\text { inversion; } \\
\text { solvent } \\
\text { evaporation }\end{array}$ & Nanofiltration & $\begin{array}{l}\text { Asymmetric structure with } \\
\text { a dense skin layer; highest } \\
\text { flux for alcohol and alkanes } \\
\text { was achieved for a } \\
50 / 50 \text { wt.\% blend; }\end{array}$ & {$[62]$} \\
\hline $\begin{array}{c}\mathrm{PPSU} / \mathrm{TiO}_{2} \\
\text { nanocomposites } \\
\text { membrane }\end{array}$ & Blending & $\mathrm{TiO}_{2}$ & $\begin{array}{c}\text { Solvent } \\
\text { evaporation }\end{array}$ & Biomedical & $\begin{array}{l}\text { Nanocomposites shown } \\
\text { active inhibition against } E \text {. } \\
\text { coli and S. aureus bacteria } \\
\text { with and without UV } \\
\text { irradiation; the stiffness, } \\
\text { strength, toughness, } \\
\text { hardness and heat distortion } \\
\text { temperature increases }\end{array}$ & [63] \\
\hline $\begin{array}{l}\text { Anion exchange } \\
\text { PyPPSU } \\
\text { membrane }\end{array}$ & Blending & $\begin{array}{l}\text { 1-methyl-2- } \\
\text { pyrrolidone }\end{array}$ & $\begin{array}{c}\text { Solvent } \\
\text { evaporation }\end{array}$ & $\begin{array}{l}\text { Vanadium redox } \\
\text { flow battery }\end{array}$ & $\begin{array}{l}\text { Vanadium ions permeability } \\
\qquad\left(0.07 \times 10^{-7}-\right. \\
\left.0.15 \times 10^{-7} \mathrm{~cm}^{2} \mathrm{~min}^{-1}\right) \\
\text { coulombic efficiency of } \\
97.8 \% \text { and energy efficiency } \\
\text { of } 80.2 \%\end{array}$ & [64] \\
\hline $\begin{array}{l}\text { PPSU solvent } \\
\text { resistant } \\
\text { membrane }\end{array}$ & Blending & Cu-BTC & $\begin{array}{l}\text { Phase } \\
\text { inversion }\end{array}$ & $\begin{array}{l}\text { Nanofiltration; } \\
\text { methanol-dye } \\
\text { separation }\end{array}$ & $\begin{array}{l}\text { Improve tensile strength } \\
29 \% \text {; methanol flux } \\
135 \mathrm{~L} \mathrm{~m}^{-2} \mathrm{~h}^{-1}\end{array}$ & {$[65]$} \\
\hline $\begin{array}{c}\text { PPSU } \\
\text { nanofibrous } \\
\text { membrane }\end{array}$ & Blending & PEG 400 & Electrospinning & $\begin{array}{l}\text { Wastewater } \\
\text { treatments }\end{array}$ & $\begin{array}{c}\text { Water contact angle } 8.9^{\circ} \text {; } \\
\text { porosity } 72.4 \% \text {; water flux } \\
7920 \mathrm{~L} / \mathrm{m}^{2} \mathrm{~h}\end{array}$ & {$[66]$} \\
\hline PPSU membranes & Blending & sPPSU & $\begin{array}{l}\text { Phase } \\
\text { inversion }\end{array}$ & Ultrafiltration & $\begin{array}{c}\text { Porosity } 48 \% \text {; MWCO } \\
70 \mathrm{kDa} \text {; pure water flux } \\
218 \mathrm{~L} \mathrm{~m}^{-2} \mathrm{~h}^{-1} \text {; FRR } 79 \% \\
\text { BSA rejection } 85 \%\end{array}$ & [49] \\
\hline $\begin{array}{l}\text { sPPSU /PIM-1 } \\
\text { membrane }\end{array}$ & Blending & sDCDPS; PIM-1 & $\begin{array}{c}\text { Slower } \\
\text { solvent } \\
\text { evaporation }\end{array}$ & Gas Separation & $\begin{array}{c}\text { The tensile strength up to } \\
72 \mathrm{MPa} \text { and extension at } \\
\text { break } 3.5 \% \text {; the gas } \\
\text { separation performance } \\
\text { above the Robeson upper } \\
\text { bounds for } \mathrm{O}_{2} / \mathrm{N}_{2}, \mathrm{CO}_{2} / \mathrm{N}_{2} \text {, } \\
\qquad \mathrm{CO}_{2} / \mathrm{CH}_{4}\end{array}$ & {$[67]$} \\
\hline
\end{tabular}


Table 1. Cont.

\begin{tabular}{|c|c|c|c|c|c|c|}
\hline Description & $\begin{array}{l}\text { Methods of } \\
\text { Modification }\end{array}$ & Modifier Agents & $\begin{array}{l}\text { Process of } \\
\text { Membrane }\end{array}$ & Application & Performance & Ref. \\
\hline $\begin{array}{l}\text { PPSU /FAC } \\
\text { composite } \\
\text { membrane }\end{array}$ & Blending & FAC & $\begin{array}{l}\text { Phase } \\
\text { inversion }\end{array}$ & Phenol filtration & $\begin{array}{l}\text { Fragmented surface and } \\
\text { spongy porous linkages; } \\
\text { contact angle } 43.8^{\circ} \text {; porosity } \\
30 \% \text {; pure water flux } 26 \\
\mathrm{Lm}^{-2} \mathrm{~h}^{-1}, \text { phenol } \\
\text { rejection } 96.4 \%\end{array}$ & [68] \\
\hline $\begin{array}{l}\mathrm{MgO} / \mathrm{sPPSU} / \mathrm{PPSU} \\
\text { membranes }\end{array}$ & Blending & $\mathrm{MgO} ; \mathrm{sPPSU}$ & $\begin{array}{l}\text { Phase } \\
\text { inversion }\end{array}$ & $\begin{array}{l}\text { Ultrafiltration; Oil } \\
\text { separation }\end{array}$ & $\begin{array}{c}\text { Porosity } 65 \% \text { and MWCO } \\
70 \mathrm{kDa} \text {; contact angle } 48^{\circ} \\
\text { FRR } 85 \% \text { and HA rejection } \\
63 \% \text { and castor oil rejection } \\
99 \%\end{array}$ & [69] \\
\hline $\begin{array}{l}\text { PPSU / Cu-BTC } \\
\text { solvent resistant } \\
\text { nanofiltration }\end{array}$ & Blending & Cu-BTC & $\begin{array}{l}\text { Phase } \\
\text { inversion }\end{array}$ & $\begin{array}{c}\text { Nanofiltration; } \\
\text { dye and methanol } \\
\text { separation }\end{array}$ & $\begin{array}{c}\text { Contact angle } 61^{\circ} \text {, and } \\
\text { porosity } 62 \% \text {; Flux } 19 \mathrm{~L} / \mathrm{m}^{2} \\
\text { h and rejection of } \\
\text { methanol } 93 \%\end{array}$ & {$[70]$} \\
\hline $\begin{array}{l}\text { sPPSU proton } \\
\text { exchange } \\
\text { membrane }\end{array}$ & $\begin{array}{l}\text { Sulfonation; } \\
\text { Blending }\end{array}$ & $\mathrm{H}_{2} \mathrm{SO}_{4}$ & $\begin{array}{c}\text { Solvent } \\
\text { evaporation }\end{array}$ & Fuel cells & $\begin{array}{l}\text { Conductivity of } 0.1 \mathrm{~S} / \mathrm{cm} \\
\text { and power density of } \\
471 \mathrm{~mW} / \mathrm{cm}^{2} \text { at } 80^{\circ} \mathrm{C}\end{array}$ & {$[71]$} \\
\hline PPSU membrane & Blending & PVP; PEG; Tween 80 & $\begin{array}{l}\text { Phase } \\
\text { inversion }\end{array}$ & Ultrafiltration & $\begin{array}{c}\text { Water flux } 148 \mathrm{~L} / \mathrm{m}^{2} \mathrm{~h} \text {; BSA } \\
\text { rejection increased from } \\
53.2 \% \text { to } 81.5 \%\end{array}$ & {$[30]$} \\
\hline $\begin{array}{l}\text { sPPSU } \\
\text { asymmetric } \\
\text { membranes }\end{array}$ & $\begin{array}{l}\text { Sulfonation; } \\
\text { Blending }\end{array}$ & TMSCIS & $\begin{array}{l}\text { Phase } \\
\text { inversion }\end{array}$ & Ultrafiltration & $\begin{array}{l}\text { Decomposition temperature } \\
\text { at } 510^{\circ} \mathrm{C} \text {; contact angle } 33^{\circ}, \\
\text { and porosity } 51 \% \text {; FRR } 70 \%\end{array}$ & {$[72]$} \\
\hline $\begin{array}{l}\text { sPPSU /f- } \\
\text { SWCNTs } \\
\text { mixed-matrix } \\
\text { membranes }\end{array}$ & $\begin{array}{l}\text { Sulfonation; } \\
\text { Blending }\end{array}$ & $\begin{array}{l}\text { 3,3'-disulfonated } \\
\text { 4, } 4^{\prime} \text {-dichlorodiphenyl } \\
\text { sulfone; f-SWCNTs }\end{array}$ & $\begin{array}{l}\text { Phase } \\
\text { inversion }\end{array}$ & Gas separation & $\begin{array}{c}\text { Enhanced the permeability } \\
\text { for } \mathrm{N}_{2}, \mathrm{O}_{2}, \mathrm{He} \text {, and } \mathrm{CO}_{2} \text { and } \\
\text { the selectivity for } \mathrm{O}_{2} / \mathrm{N}_{2} \\
\text { and } \mathrm{O}_{2} / \mathrm{CO}_{2}\end{array}$ & [73] \\
\hline $\begin{array}{l}\text { Porous PPSU } \\
\text { membrane }\end{array}$ & Blending & Carrageenan & $\begin{array}{l}\text { Phase } \\
\text { inversion }\end{array}$ & Ultrafiltration & $\begin{array}{c}\text { Contact angle } 43^{\circ} \text { and } \\
\text { porosity } 78 \% \text {; zeta potential } \\
-24 \mathrm{mV} \text { at pH } 7 \text {; } \\
\text { permeability increased up to } \\
29 \mathrm{Lm}^{-2} \mathrm{~h}^{-1} \text { bar }^{-1}\end{array}$ & {$[74]$} \\
\hline $\begin{array}{l}\text { PPSU/GO mixed } \\
\text { matrix membrane }\end{array}$ & Blending & GO; PEG1000 & $\begin{array}{l}\text { Phase } \\
\text { inversion }\end{array}$ & Ultrafiltration & $\begin{array}{l}\text { Hydrophilicity and the } \\
\text { thermal stability improved; } \\
\text { pure water flux } \\
132 \mathrm{~L} \cdot \mathrm{m}^{-2} \cdot \mathrm{h}^{-1} \text { and the } \\
\text { rejection } 96.8 \%\end{array}$ & [28] \\
\hline $\begin{array}{l}\text { PPSU / Zeolite } \\
\text { mixed matrix } \\
\text { membrane }\end{array}$ & Blending & Fe-ZSM-5; Cu-ZSM-5 & $\begin{array}{l}\text { Phase } \\
\text { inversion }\end{array}$ & $\begin{array}{l}\text { Organic } \\
\text { compounds } \\
\text { removal }\end{array}$ & $\begin{array}{l}\text { Surface roughness increased } \\
(\text { Ra- } 18.52 \mathrm{~nm}) \text {; zeta } \\
\text { potential about }-57.2 \mathrm{mV} \text { at } \\
\mathrm{pH} 7 \text {; water flux of } \\
62 \mathrm{~L} \cdot \mathrm{m}^{-2} \cdot \mathrm{h}^{-1}, \text { lignin } \\
\text { rejection up to } 88.5 \%\end{array}$ & {$[31]$} \\
\hline $\begin{array}{l}\text { PPSU / BiOCl-AC } \\
\text { membrane }\end{array}$ & Blending & BiOCl-AC; PVP & $\begin{array}{l}\text { Phase } \\
\text { inversion }\end{array}$ & $\begin{array}{l}\text { Ultrafiltration; oil } \\
\text { separation }\end{array}$ & $\begin{array}{l}\text { Asymmetric structures with } \\
\text { thick top layer; contact } \\
\text { angle } 67^{\circ} ; \text { pure water flux } \\
465 \mathrm{~L} \cdot \mathrm{m}^{-2} \cdot \mathrm{h}^{-1} \text {; rejection } \\
\text { diesel fuel } 80 \% \text { and } 90 \% \text { of } \\
\text { crude oil }\end{array}$ & {$[42]$} \\
\hline $\begin{array}{l}\text { Alkali resisting } \\
\text { PPSU membrane }\end{array}$ & Blending & $\begin{array}{c}\text { PVP- } 10,55,360 \text {, and } \\
1300 \mathrm{kDa}\end{array}$ & $\begin{array}{l}\text { Phase } \\
\text { inversion }\end{array}$ & Ultrafiltration & $\begin{array}{l}\text { Asymmetric and fingerlike } \\
\text { structure; Tensile strength } \\
\text { upto } 2.53 \mathrm{MPa} \text { for } 10 \mathrm{kDa} \\
\text { MWCO ranged from } 2 \mathrm{kDa} \\
\text { to } 175 \mathrm{kDa} \text {; pure water flux } \\
69 \mathrm{~L} \cdot \mathrm{m}^{-2} \cdot \mathrm{h}^{-1} \text {; better } \\
\text { anti-alkali property in } \\
\text { NaOH solution }(\mathrm{pH}=13)\end{array}$ & {$[13]$} \\
\hline $\begin{array}{c}\text { HBE- } \\
\text { MMT/PPSU } \\
\text { nanocomposite } \\
\text { membrane }\end{array}$ & Blending & $\begin{array}{l}\text { Functionalized } \\
\text { montmorillonite }\end{array}$ & $\begin{array}{l}\text { Phase } \\
\text { inversion }\end{array}$ & Water treatment & $\begin{array}{l}\text { Contact angle } 53.6^{\circ} \text {; pure } \\
\text { water flux about } \\
380 \mathrm{~L} \cdot \mathrm{m}^{-2} \cdot \mathrm{h}^{-1} \text { at } 5 \text { bar; } \\
\text { rejection of salt } 40-50 \%\end{array}$ & {$[75]$} \\
\hline
\end{tabular}


Table 1. Cont.

\begin{tabular}{|c|c|c|c|c|c|c|}
\hline Description & $\begin{array}{l}\text { Methods of } \\
\text { Modification }\end{array}$ & Modifier Agents & $\begin{array}{l}\text { Process of } \\
\text { Membrane }\end{array}$ & Application & Performance & Ref. \\
\hline $\begin{array}{l}\text { Polyamide TFN } \\
\text { PPSU membrane }\end{array}$ & $\begin{array}{l}\text { Blending; } \\
\text { Surface } \\
\text { modification }\end{array}$ & $\begin{array}{l}\text { GO (support } \\
\text { layer); PIP and } \\
\text { TMC }\end{array}$ & $\begin{array}{c}\text { Interfacial } \\
\text { polymerization }\end{array}$ & $\begin{array}{l}\text { Nanofiltration; } 1 \\
\text { kinetic hydrate } \\
\text { inhibitor }(\mathrm{KHI}) \\
\text { removal }\end{array}$ & $\begin{array}{l}\text { KHI rejection of } 99 \% \text { and } \\
\text { permeation flux of } \\
32.7 \mathrm{~L} / \mathrm{m}^{2} \mathrm{~h} \text { (at } 9 \text { bar and } \\
\text { feed concentration of } \\
0.5 \text { wt. } \% \mathrm{KHI})\end{array}$ & [76] \\
\hline $\begin{array}{l}\text { sPPSU } / \mathrm{TiO}_{2} \\
\text { mixed matrix } \\
\text { hollow fiber } \\
\text { membranes }\end{array}$ & Blending & $\mathrm{TiO}_{2}$ & Phase inversion & Ultrafiltration & $\begin{array}{c}\text { Pure water flux } \\
60 \mathrm{~L} \cdot \mathrm{m}^{-2} \cdot \mathrm{h}^{-1} ; \text { contact } \\
\text { angle } 67^{\circ} ; \text { rejection of BSA } \\
91 \%\end{array}$ & {$[77]$} \\
\hline PPSU membrane & Blending & $\begin{array}{c}\text { PEG 400; PEG } \\
20000\end{array}$ & Phase inversion & $\begin{array}{l}\text { Filtration of } \\
\text { aqueous media }\end{array}$ & $\begin{array}{c}\text { Porosity } 72 \% \text {; tensile } \\
\text { Strength at Break } 7.75 \mathrm{MPa} \\
\text { and elongation at Break } \\
50.14 \% ; \text { Pure water flux } \\
19 \mathrm{~L} \cdot \mathrm{m}^{-2} \cdot \mathrm{h}^{-1}(\mathrm{PEG} 400) \\
\text { and } 183 \mathrm{~L} \cdot \mathrm{m}^{-2} \cdot \mathrm{h}^{-1} \\
(\mathrm{PEG} 20000) ; 100 \% \text { turbidity } \\
\text { rejection }\end{array}$ & [10] \\
\hline PPSU membrane & Blending & $\begin{array}{l}\text { PEG 400; PEG } \\
\text { 2000; PEG 6000; } \\
\text { PEG 20000; PEG } \\
\text { 35000; PEG } 40000\end{array}$ & Phase inversion & Ultrafiltration & $\begin{array}{l}\text { Contact angle } 50^{\circ} \text { to } 90^{\circ} \\
\text { pure water flux of } \\
486 \mathrm{Lm}^{-2} \mathrm{~h}^{-1} \text {; human } \\
\text { serum albumin } \\
\text { rejection } 90 \%\end{array}$ & {$[78]$} \\
\hline $\begin{array}{l}\text { Ionic crosslinked } \\
\text { sPPSU membrane }\end{array}$ & $\begin{array}{c}\text { Surface } \\
\text { modification }\end{array}$ & HPEI & Coating & $\begin{array}{l}\text { Nanofiltration; } \\
\text { organic solvent } \\
\text { filtration }\end{array}$ & $\begin{array}{l}\text { Ethanol permeability } \\
1.47 \mathrm{~L} \mathrm{~m}^{-2} \mathrm{~h}^{-1} \mathrm{bar}^{-1} \\
\text { rejection of } 99.9 \% \text { to Rose } \\
\text { Bengal dye }\end{array}$ & [79] \\
\hline $\begin{array}{l}\text { High-Flux PPSU } \\
\text { membranes }\end{array}$ & Blending & PEG 6000-40000 & Phase inversion & Ultrafiltration & $\begin{array}{c}\text { Pure water flux } \\
500-1000 \mathrm{~L} \mathrm{~m}^{-2} \mathrm{~h}^{-1} \text { at } \\
0.1 \mathrm{MPa} ; 90 \% \text { rejection of } \\
\text { human serum albumin } \\
\text { (PEG20000) }\end{array}$ & [80] \\
\hline $\begin{array}{l}\text { PA-MOF / PPSU- } \\
\text { GO TFN } \\
\text { membrane }\end{array}$ & $\begin{array}{l}\text { Blending; Surface } \\
\text { modification }\end{array}$ & $\begin{array}{l}\text { GO (support } \\
\text { layer); MOF; PIP } \\
\text { and TMC }\end{array}$ & $\begin{array}{c}\text { Interfacial } \\
\text { polymerization }\end{array}$ & Nanofiltration & $\begin{array}{c}\text { Permeate flux } 59.9 \mathrm{~L} / \mathrm{m}^{2} \cdot \mathrm{h} ; \\
\text { KHI rejection } 96 \% \text {; FRR } \\
97.8 \% \text { and an excellent } \\
\text { long-term stability }\end{array}$ & [81] \\
\hline $\begin{array}{l}\text { sPPSU/PBI } \\
\text { membrane }\end{array}$ & $\begin{array}{l}\text { Blending; } \\
\text { crosslinking }\end{array}$ & $\begin{array}{c}\text { PBI; DBX } \\
\text { (crosslinker) }\end{array}$ & $\begin{array}{l}\text { Heat and solvent } \\
\text { evaporation }\end{array}$ & $\begin{array}{l}\text { Nanofiltration; } \\
\text { organic solvent } \\
\text { removal }\end{array}$ & $\begin{array}{c}\text { Permeability } 11.8 \mathrm{Lm}^{-2} \mathrm{~h}^{-1} \\
\text { bar }^{-1} \text {; rejection of } \\
\text { tetracycline } 97 \% .\end{array}$ & [82] \\
\hline $\begin{array}{c}\text { Double } \\
\text { crosslinked } \\
\text { sPPSU /PBI } \\
\text { membrane }\end{array}$ & $\begin{array}{c}\text { Blending; } \\
\text { crosslinking }\end{array}$ & $\begin{array}{c}\text { PBI; DBX } \\
\text { (crosslinker) }\end{array}$ & $\begin{array}{l}\text { Heat and solvent } \\
\text { evaporation }\end{array}$ & $\begin{array}{l}\text { Nanofiltration; } \\
\text { hydrogen } \\
\text { purification }\end{array}$ & $\begin{array}{c}\mathrm{H}_{2} \text { permeability of } 46.2 \\
\text { Barrer and a high } \mathrm{H}_{2} / \mathrm{CO}_{2} \\
\text { selectivity of } 9.9 \text { at } 150{ }^{\circ} \mathrm{C}\end{array}$ & [83] \\
\hline $\begin{array}{c}\text { Amine } \\
\text { functionalized } \\
\text { PPSU membrane }\end{array}$ & $\begin{array}{l}\text { Amination; } \\
\text { Blending }\end{array}$ & $\mathrm{SnCl}_{2} ; \mathrm{HNO}_{3}$ & Phase inversion & $\begin{array}{l}\text { Nanofiltration; } \\
\text { dye removal }\end{array}$ & $\begin{array}{c}\text { Pore size of } 0.72 \mathrm{~nm} ; \\
\text { positively charged active } \\
\text { layers; contact angles } 31^{\circ} ; \\
\text { pure water flux } \\
\sim 54 \mathrm{Lm}^{-2} \mathrm{~h}^{-1} ; \mathrm{CaCl}_{2} \text { and } \\
\mathrm{AlCl}_{3} \text { multivalent salts } \\
\text { rejection } 89 \% \text { and } 93.5 \% \text {; } \\
\text { crystal violet dye rejection } \\
>99 \%\end{array}$ & [84] \\
\hline $\begin{array}{l}\text { High- } \\
\text { performance } \\
\text { PPSU/sPANI } \\
\text { membrane }\end{array}$ & Blending & sPANI & $\begin{array}{l}\text { Nonsolvent } \\
\text { induced phase } \\
\text { separation }\end{array}$ & Ultrafiltration & $\begin{array}{c}\text { Contact angle was } 57^{\circ} ; \\
\text { porosity } 81 \% \text {; BSA } \\
\text { adsorption value of } \\
3.6 \mu \mathrm{g} / \mathrm{cm}^{2} ; \text { water flux of } \\
260 \mathrm{~L} / \mathrm{m}^{2} \mathrm{~h} \text {; BSA } \\
\text { rejection } 95 \%\end{array}$ & {$[40]$} \\
\hline $\begin{array}{l}\text { PPSU/carboxylated } \\
\text { GO } \\
\text { nanocomposite } \\
\text { membrane }\end{array}$ & Blending & Carboxylated GO & Phase inversion & $\begin{array}{l}\text { Nanofiltration; } \\
\text { heavy metal } \\
\text { removal }\end{array}$ & $\begin{array}{c}\text { Surface charge of }-70 \mathrm{mV} \\
\text { flux of } 27 \mathrm{~L} \mathrm{~m}^{-2} \mathrm{~h}^{-1} \\
\text { rejection of } \mathrm{As}(\mathrm{V}) 96 \% \\
\mathrm{Cr}(\mathrm{VI}) 93 \%, \mathrm{Zn}^{2+}(81 \%) \\
\mathrm{Cd}^{2+}(74 \%), \mathrm{Pb}^{2+}(73 \%)\end{array}$ & [85] \\
\hline
\end{tabular}


Table 1. Cont.

\begin{tabular}{|c|c|c|c|c|c|c|}
\hline Description & $\begin{array}{l}\text { Methods of } \\
\text { Modification }\end{array}$ & Modifier Agents & $\begin{array}{l}\text { Process of } \\
\text { Membrane }\end{array}$ & Application & Performance & Ref. \\
\hline sPPSU membrane & Sulfonation & $\mathrm{H}_{2} \mathrm{SO}_{4}$ & Phase inversion & $\begin{array}{l}\text { Ultrafiltration; } \\
\text { heavy metal and } \\
\text { protein } \\
\text { separation }\end{array}$ & $\begin{array}{c}\text { Water flux of } 190.33 \\
\mathrm{Lm}^{-2} \mathrm{~h}^{-1} \text { and FRR of } \\
86.56 \% \text {; protein rejection of } \\
66.3 \%, 74.0 \% \text { and } 91.2 \% \text { for } \\
\text { trypsin, pepsin, and BSA; } \\
\mathrm{Cd}^{2+} \\
\text { and } \mathrm{Pb}^{2+} \text { ions rejection of } \\
75.2 \% \text { and } 87.6 \% \text {; }\end{array}$ & {$[86]$} \\
\hline $\begin{array}{l}\text { PPSU/carboxylated } \\
\text { GO } \\
\text { nanocomposite } \\
\text { membrane }\end{array}$ & Blending & Carboxylated GO & Phase inversion & $\begin{array}{l}\text { Ultrafiltration; } \\
\text { Antimicrobial } \\
\text { and antifouling }\end{array}$ & $\begin{array}{c}\text { Bacteriostasis rates of } \\
74.2 \%, 81.1 \% \text { and } 41.9 \% \\
\text { against E. coli, P. aeruginosa } \\
\text { and S. aureus; FRR } 95.3 \%\end{array}$ & {$[87]$} \\
\hline $\begin{array}{l}\text { Porous } \\
\text { PPSU/sPEEK } \\
\text { membrane }\end{array}$ & Blending & sPEEK & $\begin{array}{c}\text { Solvent } \\
\text { evaporation }\end{array}$ & $\begin{array}{l}\text { Vanadium flow } \\
\text { batteries }\end{array}$ & $\begin{array}{c}\text { Contact angle } 47^{\circ} \text {; tensile } \\
\text { strength } 2.78 \mathrm{MPa} \text {; proton } \\
\text { conductivity of } \\
14.3 \mathrm{mS} \mathrm{cm}^{-1} \text { at } 15^{\circ} \mathrm{C}\end{array}$ & {$[88]$} \\
\hline $\begin{array}{l}\mathrm{PPSU} / \mathrm{SnO}_{2} \\
\text { mixed matrix } \\
\text { hollow fiber } \\
\text { membrane }\end{array}$ & Blending & $\mathrm{SnO}_{2}$ & $\begin{array}{l}\text { Vacuum } \\
\text { evaporation }\end{array}$ & $\begin{array}{l}\text { Ultrafiltration; } \\
\text { dyes removal }\end{array}$ & $\begin{array}{l}\text { Contact angle } 63^{\circ} \text {; porosity } \\
84 \% \text {; pure water flux } \\
362.9 \mathrm{~L} / \mathrm{m}^{2} \mathrm{~h} \text {; dyes rejection } \\
\text { about }>94 \% \text { for RB- } 5 \text {, and } \\
>73 \% \text { for RO- } 16\end{array}$ & [89] \\
\hline $\begin{array}{c}\text { PPSU } / \mathrm{CuO} / \mathrm{g}- \\
\mathrm{C}_{3} \mathrm{~N}_{4} \\
\text { membrane }\end{array}$ & Blending & $\mathrm{CuO} / \mathrm{g}-\mathrm{C}_{3} \mathrm{~N}_{4}$ & $\begin{array}{l}\text { Nonsolvent } \\
\text { induced phase } \\
\text { inversion }\end{array}$ & $\begin{array}{l}\text { Ultrafiltration; } \\
\text { antifouling and } \\
\text { protein } \\
\text { separation }\end{array}$ & $\begin{array}{c}\text { Smooth surfaces Ra- } 9.8 \mathrm{~nm} \text {; } \\
\text { increase pores on the top } \\
\text { layer as well as in the } \\
\text { sublayer; contact angle } 48^{\circ} \text {; } \\
\text { water flux } 202 \mathrm{~L} / \mathrm{m}^{2} \mathrm{~h} \text {; BSA } \\
\text { protein rejection } 96 \% \text {; FRR } \\
79 \%\end{array}$ & {$[90]$} \\
\hline $\begin{array}{l}\text { Super- } \\
\text { hydrophilic PPSU } \\
\text { TFC membrane }\end{array}$ & $\begin{array}{l}\text { Surface } \\
\text { modification }\end{array}$ & MPD and TMC & $\begin{array}{l}\text { Electrospun; } \\
\text { plasma } \\
\text { treatments; } \\
\text { interfacial } \\
\text { polymerization }\end{array}$ & Forward osmosis & $\begin{array}{l}\text { Contact angle } 0^{\circ} ; \text { Osmotic } \\
\text { water flux } 14 \mathrm{~L} / \mathrm{m}^{2} \mathrm{~h}\end{array}$ & [91] \\
\hline $\begin{array}{l}\text { PPSU hollow } \\
\text { fiber membranes }\end{array}$ & Blending & $\mathrm{CA} ; \mathrm{CAP}$ & Dry-wet spinning & $\begin{array}{l}\text { Ultrafiltration; } \\
\text { arsenic removal }\end{array}$ & $\begin{array}{c}\text { Contact angle } 60^{\circ} \text { and } 43^{\circ} \text {; } \\
\text { arsenic removal } 34 \% \text { and } \\
41 \% \text {; pure water } \\
\text { permeability } 61.47 \mathrm{~L} / \mathrm{m}^{2} \mathrm{~h} \\
\text { bar and } 69.60 \mathrm{~L} / \mathrm{m}^{2} \mathrm{~h} \text { bar; } \\
\text { FRR } 88.67 \%\end{array}$ & [92] \\
\hline $\begin{array}{l}\text { PPSU/silver- } \\
\text { hydroxyapatite } \\
\text { nanocomposite } \\
\text { membrane }\end{array}$ & Blending & $\begin{array}{l}\text { silver- } \\
\text { hydroxyapatite }\end{array}$ & Phase inversion & $\begin{array}{l}\text { Ultrafiltration; } \\
\text { organic matter } \\
\text { removal }\end{array}$ & $\begin{array}{l}\text { Porous and honeycomblike } \\
\text { structure; contact angle } 60^{\circ} ; \\
\text { rejection } 89 \%\end{array}$ & [93] \\
\hline $\begin{array}{l}\text { Proton exchange } \\
\text { sulfonated } \\
\text { PPSU / PSU } \\
\text { membrane }\end{array}$ & Sulfonation & $\begin{array}{l}\text { Trimethylsilyl } \\
\text { chlorosulfonate; }\end{array}$ & Vacuum dry & Fuel cells & $\begin{array}{c}\text { Proton conductivity } \\
34.1 \mathrm{mS} \mathrm{cm}^{-1} \text { at } 70^{\circ} \mathrm{C} ; \\
\text { power density of } 400 \\
\mathrm{~mW} \mathrm{~cm} \mathrm{~cm}^{-2} ; \text { current density } \\
\text { of } 1100 \mathrm{~mA} \mathrm{~cm}^{-2}\end{array}$ & [35] \\
\hline $\begin{array}{c}\text { PPSU/Ag- } \\
\text { MWCNTs } \\
\text { nanocomposite } \\
\text { membrane }\end{array}$ & Blending & Ag-MWCNTs & Phase inversion & $\begin{array}{c}\text { Nanofiltration; } \\
\text { ion removal and } \\
\text { antibacterial } \\
\text { activity }\end{array}$ & $\begin{array}{c}\text { Zeta potential }-78 \mathrm{mV} \\
\text { contact angle } 49^{\circ} ; \text { porosity } \\
73 \% \text {; rejection of } \mathrm{Na}_{2} \mathrm{HAsO}_{4} \\
99.5 \% \text { and } \mathrm{Na}_{2} \mathrm{Cr}_{2} \mathrm{O}_{7} 100 \%\end{array}$ & [87] \\
\hline $\begin{array}{l}\text { PPSU / MWCNTs } \\
\text { membrane }\end{array}$ & Blending & MWCNTs & Phase inversion & $\begin{array}{l}\text { Ultrafiltration; } \\
\text { heavy metals } \\
\text { removal }\end{array}$ & $\begin{array}{l}\text { Dense skin layer on top and } \\
\text { a porous supportive } \\
\text { sub-layer; surface roughness } \\
\text { Ra } 21 \mathrm{~nm} \text {; contact angle } 61^{\circ} \text {; } \\
\text { porosity } 50 \% \text {; flux } \\
186 \mathrm{~L} / \mathrm{m}^{2} \mathrm{~h} \text { rejection of } \mathrm{Pb}^{2+} \\
(>98 \%), \mathrm{Hg}^{2+}(>76 \%) \text { and } \\
\mathrm{Cd}^{2+}(>72 \%)\end{array}$ & {$[94]$} \\
\hline
\end{tabular}


Table 1. Cont.

\begin{tabular}{|c|c|c|c|c|c|c|}
\hline Description & $\begin{array}{l}\text { Methods of } \\
\text { Modification }\end{array}$ & Modifier Agents & $\begin{array}{l}\text { Process of } \\
\text { Membrane }\end{array}$ & Application & Performance & Ref. \\
\hline $\begin{array}{c}\mathrm{PPSU} / \mathrm{ZnO} \\
\text { nanocomposite } \\
\text { membrane }\end{array}$ & Blending & $\mathrm{ZnO}$ & Phase inversion & $\begin{array}{l}\text { Nanostructured- } \\
\text { hybrid } \\
\text { membranes; } \\
\text { anionic dye; } \\
\text { antimicrobial; } \\
\text { wastewater } \\
\text { treatment }\end{array}$ & $\begin{array}{c}\text { Pore size } 0.75 \mathrm{~nm} \text {; zeta } \\
\text { potential }-65.7 \mathrm{mV} \text { at } \mathrm{pH} 7 \\
\text { methyl orange dye rejection } \\
98 \% \text { with a water flux } \\
19 \mathrm{~L} / \mathrm{m}^{2} \mathrm{~h} \text {; antibacterial } \\
\text { activity of } \text { E. coli }(6.2) \text { and } S \text {. } \\
\text { aureus }(6.8)\end{array}$ & [95] \\
\hline $\begin{array}{l}\text { Hydrophilic } \\
\text { PPSU membranes }\end{array}$ & Blending & $\begin{array}{l}\text { 1,2-propandiol; } \\
\text { PVP }\end{array}$ & $\begin{array}{l}\text { Nonsolvent } \\
\text { induced phase } \\
\text { separation }\end{array}$ & Ultrafiltration & $\begin{array}{c}\text { Contact angles of } \\
46.4^{\circ} ; \text { Water flux } \\
674 \mathrm{~kg} \mathrm{~m}^{-2} \mathrm{bar}^{-1} \mathrm{~h}^{-1}\end{array}$ & [96] \\
\hline $\begin{array}{l}\mathrm{PPSU} / \mathrm{PES} / \mathrm{SiO}_{2} \\
\text { nanocomposite } \\
\text { membrane }\end{array}$ & Blending & PES; $\mathrm{SiO}_{2}$ & $\begin{array}{l}\text { Vapor induced } \\
\text { phase separation; } \\
\text { nonsolvent } \\
\text { induced phase } \\
\text { separation }\end{array}$ & Ultrafiltration & $\begin{array}{l}\text { Water flux } 76.65 \mathrm{~L} / \mathrm{m}^{2} \cdot \mathrm{h} \text {; } \\
\text { BSA retention of } 82.01 \% \text {; }\end{array}$ & [97] \\
\hline $\begin{array}{l}\text { Silica filled } \\
\text { PPSU/PDMS } \\
\text { Composite } \\
\text { Membranes }\end{array}$ & $\begin{array}{l}\text { Surface } \\
\text { modification }\end{array}$ & PDMS; Silica & Coating & $\begin{array}{l}\text { Biobutanol } \\
\text { Separation }\end{array}$ & $\begin{array}{c}\text { Weight loss starts from } \\
400^{\circ} \mathrm{C} \text {; contact angle } \sim 130^{\circ} \text {; } \\
\text { flux } 536 \mathrm{~g} . \mathrm{m}^{-2} \mathrm{~h}^{-1} ; \text { butanol } \\
\text { separation factor } 30.6\end{array}$ & {$[36]$} \\
\hline $\begin{array}{l}\text { PPSU / PANI } \\
\text { hollow fiber } \\
\text { membrane }\end{array}$ & Blending & PANI & $\begin{array}{l}\text { Dry-jet wet } \\
\text { spinning }\end{array}$ & $\begin{array}{l}\text { Humic acid } \\
\text { removal }\end{array}$ & $\begin{array}{c}\text { Zeta potential }-16 \mathrm{mV} \text { at } \\
\mathrm{pH} 9 ; \text { Water flux } 127 \mathrm{~L} / \mathrm{m}^{2} \mathrm{~h} ; \\
\text { Humic acid rejection } 98 \%\end{array}$ & [98] \\
\hline $\begin{array}{l}\text { Proton exchange } \\
\text { sPPSU membrane }\end{array}$ & Sulfonation & $\begin{array}{c}\mathrm{H}_{2} \mathrm{SO}_{4} ; \mathrm{CNDs} \\
\text { (crosslinker) }\end{array}$ & Vacuum dry & Fuel cells & $\begin{array}{l}\text { Proton conductivity } \\
10^{-2} \mathrm{~S} / \mathrm{cm} \text { at } 120^{\circ} \mathrm{C} \text {. }\end{array}$ & [99] \\
\hline $\begin{array}{l}\text { PPSU / Al-MOF } \\
\text { mixed matrix } \\
\text { membrane }\end{array}$ & Blending & Al-MOF & Phase inversion & $\begin{array}{l}\text { Ultrafiltration,; } \\
\text { dye separation; } \\
\text { antifouling }\end{array}$ & $\begin{array}{c}\text { Contact angle } 63^{\circ} \text {; surface } \\
\text { roughness Ra } 21.9 \mathrm{~nm} \text {; pure } \\
\text { water flux } 47 \mathrm{~L} \cdot \mathrm{m}^{-2} \cdot \mathrm{h}^{-1} \\
\text { FRR } 93 \% \text {; rejection of } \\
\text { organic dye methyl } \\
\text { violet } 93.8 \%\end{array}$ & {$[100]$} \\
\hline $\begin{array}{l}\mathrm{PPSU} / \mathrm{CA} / \mathrm{ZrO}_{2} \\
\text { hollow fiber } \\
\text { membranes }\end{array}$ & Blending & $\mathrm{CA} ; \mathrm{ZrO}_{2}$ & Dry-wet spinning & Arsenic Removal & $\begin{array}{l}\text { Surface roughness Ra } 43 \mathrm{~nm} \text {; } \\
\text { contact angle } 48^{\circ} ; \\
\text { permeability of } \\
89.94 \mathrm{~L} / \mathrm{m}^{2} \mathrm{~h} \text { bar; removal of } \\
\text { arsenic } 87 \%\end{array}$ & {$[45]$} \\
\hline $\begin{array}{l}\text { PPSU/CA hollow } \\
\text { fiber membrane }\end{array}$ & Blending & CA & Dry-wet spinning & Removal of dyes & $\begin{array}{l}\text { Permeability } 64.47 \mathrm{~L} / \mathrm{m}^{2} \\
\text { h bar; removal of Reactive } \\
\text { black } 5 \text { dye } 95 \%\end{array}$ & [101] \\
\hline $\begin{array}{l}\text { PPSU / Zn-MOF } \\
\text { composite } \\
\text { membrane }\end{array}$ & Blending & $\mathrm{Zn}-\mathrm{MOF}$ & Phase inversion & $\begin{array}{l}\text { Ultrafiltration; } \\
\text { antifouling }\end{array}$ & $\begin{array}{l}\text { Asymmetric structure and } \\
\text { dense microporous active } \\
\text { skin layer; surface } \\
\text { roughness Ra } 13.88 \mathrm{~nm} \text {; } \\
\text { porosity } 72 \% \text {; tensile } \\
\text { strength } 7.9 \mathrm{MPa} ; \\
\text { permeability } \\
33 \mathrm{~L} \mathrm{~m}^{-2} \mathrm{~h}^{-1} \text { bar }^{-1} \text {; FRR } \\
98 \%\end{array}$ & [102] \\
\hline $\begin{array}{l}\mathrm{PPSU} / \mathrm{CA} / \mathrm{ZnO}- \\
\mathrm{MgO} \text { hollow fiber } \\
\text { membrane }\end{array}$ & Blending & $\mathrm{CA} ; \mathrm{ZnO}-\mathrm{MgO}$ & $\begin{array}{l}\text { Dry-wet phase } \\
\text { inversion }\end{array}$ & Arsenic removal & $\begin{array}{c}\text { contact angle } 60^{\circ} ; \\
\text { permeability } 69.58 \mathrm{~L} / \mathrm{m}^{2} \mathrm{~h} \\
\text { bar; arsenic rejection } 81.31 \% \text {; } \\
\text { FRR } 91 \%\end{array}$ & [103] \\
\hline $\begin{array}{c}\text { PANI coated } \\
\text { PPSU Membranes }\end{array}$ & $\begin{array}{l}\text { Surface } \\
\text { modification }\end{array}$ & PANI & Coating & $\begin{array}{l}\text { Dye separation; } \\
\text { antibacterial } \\
\text { activities }\end{array}$ & $\begin{array}{c}\text { Surface roughness } \\
\text { Ra-3.15 nm; contact angle } \\
55^{\circ} \text {; zeta potential }-1.7 \mathrm{mV} \\
\text { at } \mathrm{pH} 6 \text {; permeability } \\
53 \mathrm{~L} \cdot \mathrm{m}^{-2} \cdot \mathrm{h}^{-1} \cdot \mathrm{bar}^{-1} ; \\
\text { rejection of methylene blue } \\
\text { dye } 96 \% \text {; bacteriostasis of } E \text {. } \\
\text { coli } 95 \% \text { and } S \text {. aureus } 88 \%\end{array}$ & [104] \\
\hline
\end{tabular}




\section{Bulk Modification}

\subsection{Polyphenylsulfone Sulfonation}

Sulfonation is defined as an aromatic electrophilic substitution reaction used to attach the sulfonic acid group to the molecule of an organic compound via a chemical bond, wherein an ortho positions the aromatic ring in place of the hydrogen atom. It is attributed to the fact that this electron-donating oxygen atom activates the ortho position [35,40,44,105-108]. Sulfonation is the accumulation of sulfonic groups at the aromatic backbone (including a phenyl and a sulfone unit as part of the backbone) of PPSU due to electron-donating substituents enhancing sulfonation. However, electron repulsing substituents have the opposite effect. PPSU is difficult to sulfonate because of the electron-withdrawing effect of the sulfone linkages that deactivate the adjacent aromatic rings for electrophilic substitution [9,51,72,109-111]. Moreover, its sulfonation requires stronger reagents and/or longer times. However, sulfonated PPSU features increased hydrophilicity and proton conductivity in the presence of sulfonate groups in the polymer chain. The latter, however, can introduce negative charges.

The sulfonation of the aromatic backbone of the polymer is carried out before membrane fabrication using sulfonating agents. There are three groups of sulfonating agents that do not cause polymer chain degradation. Sulfuric acid $\left(\mathrm{H}_{2} \mathrm{SO}_{4}\right)$, sulfur trioxide $\left(\mathrm{SO}_{3}\right)$, chlorosulfonic acid $\left(\mathrm{ClSO}_{3} \mathrm{H}\right)$, fluorosulfonic acid $\left(\mathrm{FHO}_{3} \mathrm{~S}\right)$, amidosulfonic acid $\left(\mathrm{H}_{3} \mathrm{NO}_{3} \mathrm{~S}\right)$ and its complexes, halogen derivatives of sulfuric acid, etc., form the first group and are derived from sulfur trioxide. They are referred to as electrophilic reacting agents and are most frequently used to sulfonate aromatic compounds. The second group includes nucleophilic agents such as sulfites $\left(\mathrm{SO}_{3}{ }^{2-}\right)$, hydrogen sulfites $\left(\mathrm{HO}_{3} \mathrm{~S}^{-}\right)$, and sulfur dioxide $\left(\mathrm{SO}_{2}\right)$, which react with halogen derivatives and unsaturated compounds containing multiple bonds. The third group contains radically reacting agents. In particular, it includes sulfuryl chloride $\left(\mathrm{SO}_{2} \mathrm{Cl}_{2}\right)$ and blends of gases (sulfur dioxide and chlorine $\left(\mathrm{SO}_{2}+\mathrm{Cl}_{2}\right)$, sulfur dioxide, and oxygen $\left.\left(\mathrm{SO}_{2}+\mathrm{O}_{2}\right)\right)$. Sulfonation of polymer can be completed via either a heterogeneous reaction or a homogeneous reaction in hydrocarbons or chlorinated solvents.

The polymer sulfonation method works for most reagents. In the sulfonation protocol, the dried polymer is dissolved in a sulfonating agent and stirred at approximately $50{ }^{\circ} \mathrm{C}$ to produce a homogeneous solution in a nitrogen atmosphere. After the reaction, the solution is poured into a large volume of ice-cold deionized water under continuous stirring. As a result, a white precipitate is obtained. After standing overnight, the white precipitate is filtered and washed several times with cold deionized water to attain neutral $\mathrm{pH}$ level. The sulfonated polymer is then dried in a vacuum at room temperature $[5,55,86,107]$.

A typical procedure is described by Hartmann-Thompson et al. [112] PPSU was added to dichloromethane $\left(\mathrm{CH}_{2} \mathrm{Cl}_{2}\right)$, mixed, and placed in an ice bath on a stirring plate. Next, the solution was cooled to $10^{\circ} \mathrm{C}$ under agitation. $\mathrm{ClSO}_{3} \mathrm{H}$ was added by drops over a one-hour period while stirring continuously. In the next step, acetic anhydride was added to the mixture by drops. The reaction was then allowed to continue for a period of time while stirring and maintaining the temperature. The reaction was stopped by gradually pouring the reacted solution into an ice-deionized water mixture. The resultant precipitate was recovered by pouring and washed repeatedly with deionized water until the wash water had a neutral $\mathrm{pH}$. The PPSU was subsequently dried in an oven. Minor variations have been reported by other researchers, and a generalized overview of the sulfonation reaction scheme is shown in Figure 4a $[107,113]$.

Liu et al. [9] demonstrated the sulfonation of PPSU random copolymers with various disulfonation levels. These were prepared via the direct polymerization method by aromatic nucleophilic substitution copolymerization. The reaction mechanism for this direct sulfonation has also been outlined. Karlsson et al. [52] prepared SPPSU by an anionic modification using n-butyllithium (BuLi) as a metalating agent. The preparation was performed via a one-pot synthesis in a reactor equipped with a gas inlet/outlet. In this method, the PPSU was dissolved in anhydrous tetrahydrofuran (THF) and cooled. The polymer solution was carefully titrated with a solution of BuLi until a faint reddish 
color was achieved. Subsequently, an amount of 2-sulfobenzoic acid cyclic anhydride corresponding to a twofold excess in relation to the lithiated sites of the polymer was quickly added in the form of a fine degassed powder and immediately dissolved and quenched the lithiated sites. Next, SPPSU was precipitated to remove the reactant residues via isopropanol. The precipitate was then filtered and dried in a vacuum and characterized by combining FTIR, ${ }^{1} \mathrm{H} \mathrm{nmR}$, and ${ }^{13} \mathrm{C} \mathrm{nmR}$ spectroscopy. Licoccia and coworkers [55] followed the same methodology for sulfonated PPSU with $\mathrm{H}_{2} \mathrm{SO}_{4}$ and $\mathrm{ClSO}_{3} \mathrm{Si}\left(\mathrm{CH}_{3}\right)_{3}$.

(a)

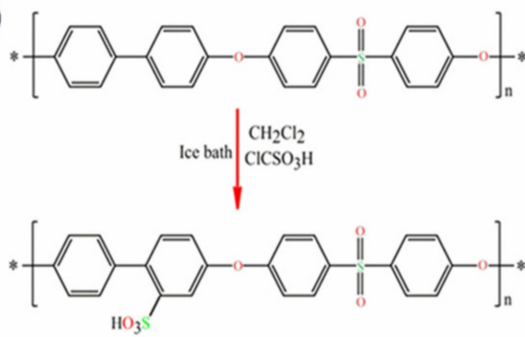

(c)

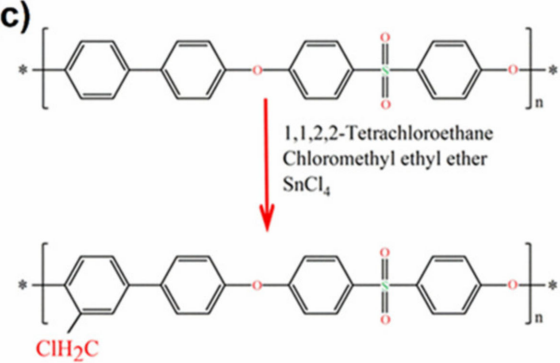

(b)

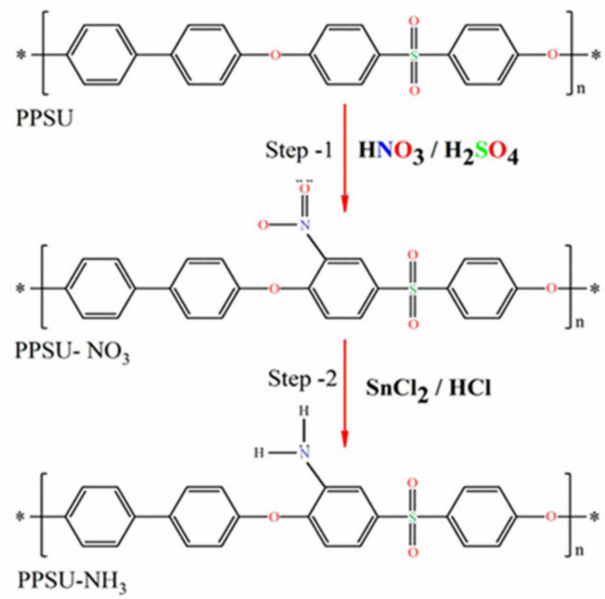

Figure 4. Synthesis of polyphenylsulfone. Reaction pathways: (a) sulfonation; (b) amination; (c) chloromethylation.

$\mathrm{H}_{2} \mathrm{SO}_{4}$ is a low-cost sulfonating agent. However, it causes degradation of the main polymer chain when the reaction temperature is too high, or the reaction time is too long. This degradation may change the mechanical resistance of the membrane, therefore compromising its use in industrial applications. Among other reagents, the sulfonated PPSU with $\mathrm{ClSO}_{3} \mathrm{Si}\left(\mathrm{CH}_{3}\right)_{3}$ showed better sulfonation control when compared to the one sulfonated with $\mathrm{SO}_{3}[51,72]$. However, $\mathrm{SO}_{3}$ has a drawback in that side reactions may occur. Moreover, the reaction is heterogeneous because when a part of the polymer reacts with $\mathrm{SO}_{3}$, it becomes insoluble in an apolar solvent. The rest of the reaction must be carried out in a dispersed system and not in a homogeneous solution. To solve the heterogeneity problem, $\mathrm{ClSO}_{3} \mathrm{Si}\left(\mathrm{CH}_{3}\right)_{3}$ can be used.

\subsection{Polyphenylsulfone Amination}

In the core of sulfonic groups, the existence of an amine group can enhance the physicochemical properties of the membrane compared to the others formed by segments. This process involves a similar substitution reaction but with amine groups as substituents. PPSU can be simply nitrated to almost one nitrogen atom per reproductive unit via reactions with strong bases. The latter is due to the sulfonic group having a strong activation effect on the nitration process. In this nitration reaction, the acidic ortho-to-sulfone hydrogens are replaced with nitrogen atoms that result in a positive charge of the carbon atom in the phenylene unit. Arumugham et al. [84] used a two-step method for the amination of PPSU. The reaction scheme for amine-functionalized PPSU is shown in Figure $4 \mathrm{~b}$. In the first step, nitration of PPSU was performed with nitric and sulfuric acid. It resulted in nitrogen atoms being placed in the ortho position. In the second step, the intermediate was aminated using tin chloride with hydrochloric acid. A similar polymer amination procedure has also been applied by other researchers [114,115]. 
Aminated polymer synthesis was followed by the reaction in a nitrogen atmosphere. PPSU (10 g) was added to a mixture of sulfuric acid and nitric acid (1/4 mixing ratio, $200 \mathrm{~mL}$ ) and then stirred for $2 \mathrm{~h}$ at $25{ }^{\circ} \mathrm{C}$ to produce nitrated PPSU (PPSU-NO $\mathrm{NO}_{2}$ ). The resulting product was washed with five times the deionized water $(300 \mathrm{~mL})$ and dried in a vacuum oven at $30^{\circ} \mathrm{C}$ for $24 \mathrm{~h}$. To synthesize aminated PPSU, the tin chloride ( $20 \mathrm{~g}$, $0.105 \mathrm{~mol}$ ) in hydrochloric acid solution $(20 \mathrm{~g}, 37 \%)$ was added in $60 \mathrm{~mL}$ of ethanol in a circular bottom flask. The flask was kept at $70{ }^{\circ} \mathrm{C}$ and then allowed to stir for $10 \mathrm{~min}$. Subsequently, the synthesized PPSU-NO ${ }_{2}(5 \mathrm{~g})$ powder was added slowly to the flask. The color of the solution transformed from yellow to dark brown, indicating the progress of the reaction. The reaction was further carried out for $4 \mathrm{~h}$ with stirring at $70^{\circ} \mathrm{C}$. Afterward, the reaction mixture was poured into $400 \mathrm{~mL}$ of deionized water for precipitation. Finally, PPSU-NH2 was separated, washed with deionized water, and dried in a vacuum oven at $80^{\circ} \mathrm{C}$ for $12 \mathrm{~h}$ [84]. Considered amino groups have a significant effect on the surface charge and hydrophilicity of the PPSU polymer, as was shown in ion exchange capacity and water absorption measurements.

\subsection{Polyphenylsulfone Chloromethylation}

PPSU is a polymer that has no functional groups for further chemical modifications. However, the chloromethylation reaction of aromatic polymers is of particular interest to researchers and includes attaching functional groups onto aromatic ring-like chloromethyl. Currently, chloromethylation is actively investigated, both theoretically and experimentally, in the context of the procurement of precursors for functional membranes. Chloromethyl generally provides higher flexibility with time since it can easily interact with any kind of amines. Once a functional group is attached to the aromatic ring, further reactions can occur, including immobilization of compounds for enhanced hemocompatibility resulting in antifouling capability [116]. Zhang et al. [64] carried out the chloromethylation of PPSU and cast anion exchange membranes from the resultant chloromethylated PPSU. Chloromethylation of PPSU was performed following the one-step procedure. In a typical reaction shown in Figure 4c, the PPSU was dissolved in tetrachloroethane, and then tin tetrachloride and chloromethyl ethyl ether were added to the solution. The reaction mixture was heated, and the temperature was maintained.

After the desired reaction time elapsed, the reaction mixture was precipitated in excess ethanol, and the chloromethylated PPSU polymers were isolated by filtration. The polymer was purified by dissolution in chloroform and precipitation with ethanol and then dried in a vacuum oven. Chloromethylation of the polymer was not easy to control, and the number of chloromethyl groups attached to the polymer could be very small. The latter affected the properties of the membrane. The reaction mixture often produced a gel if it was not properly controlled by adjusting the temperature and the reaction time. Most of the studies considered chloromethylation of the polymers with the system made from trioxane and chlorotrimethylsilane as an agent of chloromethylation in the presence of tin tetrachloride $[117,118]$. The chloromethylation of polymers was dependent primarily on the kind of chloromethylating agent, the polymer structure, the type and amount of solvent, the catalyst, and other parameters of the reaction.

\section{Polymer Blending}

Polymer blending is an emerging research area in polymer science and engineering that aims to improve polymer properties. Blending is the physical mixing of two or more polymers that belong to the same chemical family or to different ones, such as homopolymers or copolymers and organic-inorganic materials [119-124]. These materials have attracted researchers' interest due to their ability to modify the properties of other materials for particular applications. Earlier researchers obtained polymer blends from natural materials [125-127]. This technique is straightforward, fast, and cost-saving compared to other tedious and time-consuming methods. Today, bottom-up and top-down approaches are among the most used. Polymer blending makes obtaining products with superior 
properties compared with pure polymer materials possible $[128,129]$. When blending with hydrophilic additives, the structure and chemical properties of PPSU membranes can be easily modified. Multiple modifications of PPSU blends were suggested in the last 15 years. The majority of these PPSU were blended with other polymers for the synthesis of new PPSU-based membranes. Figure 5 summarizes the number of articles on PPSU blends indexed using the Web of Science.
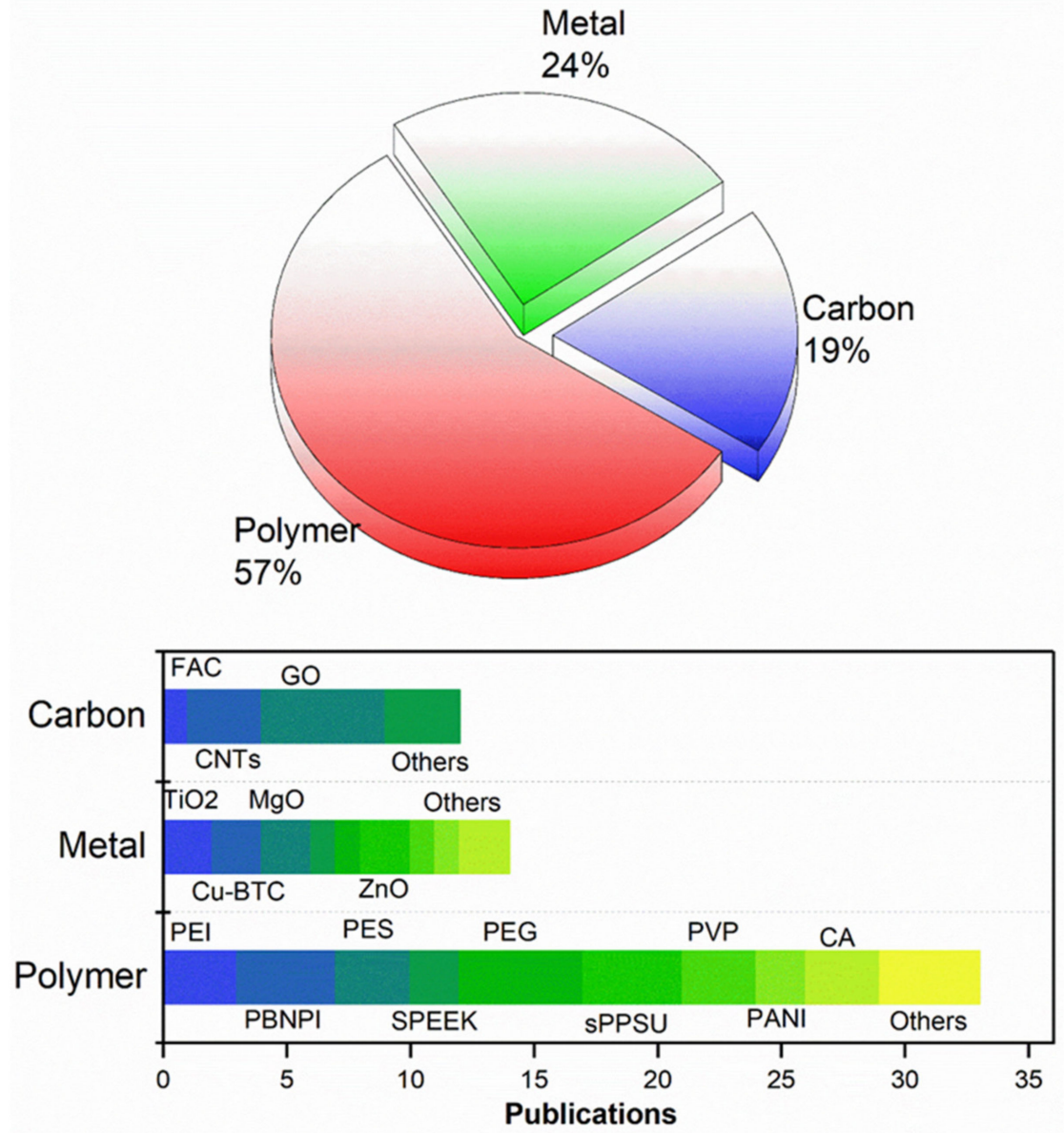

Figure 5. A number of articles on polyphenylsulfone blending indexed in Web of Science for "PPSU blend membrane". Search results and details are provided in Table 1.

\subsection{Polyphenylsulfone Blended with the Polymer}

PPSU blends with other polymers are considered one of the most practical methods to modify the membranes. More specifically, they brought together the synergistic properties of different polymer materials into a new mixed matrix with targeted structural characteristics and performance. Such an approach allowed the modification to overcome the deficiencies of the individual PPSU polymers. Moreover, polymer-polymer blends are cost-efficient, simple to obtain, and reproducible. At the same time, PPSU blends have some limitations in mixing with other polymers. This drawback affects the miscibility of the blends at the molecular level [56,83,130-135]. Thus, three types of blending mechanisms can be identified. The first one involves the two polymeric materials with single-phase properties that are dissolved in each other at the molecular level. The process is attributed to physical forces and hydrogen bonding and is known as miscible blending [120,136-138]. The second blending mechanism assumes that the two polymeric materials do not dissolve in each other and form the interface between components. This mechanism is referred to as immiscible blending [20,53,139-142]. Finally, the third mechanism implies that one polymeric material partially dissolves into another polymeric material during the heterogeneous phase. This behavior is known as partially miscible blending [143-146]. Whereas 
a number of research reports exist on the blending of other polymers, these reports have described the concept of physically blending two or more polymers with PPSU to obtain the new PPSU product (Figure 6).

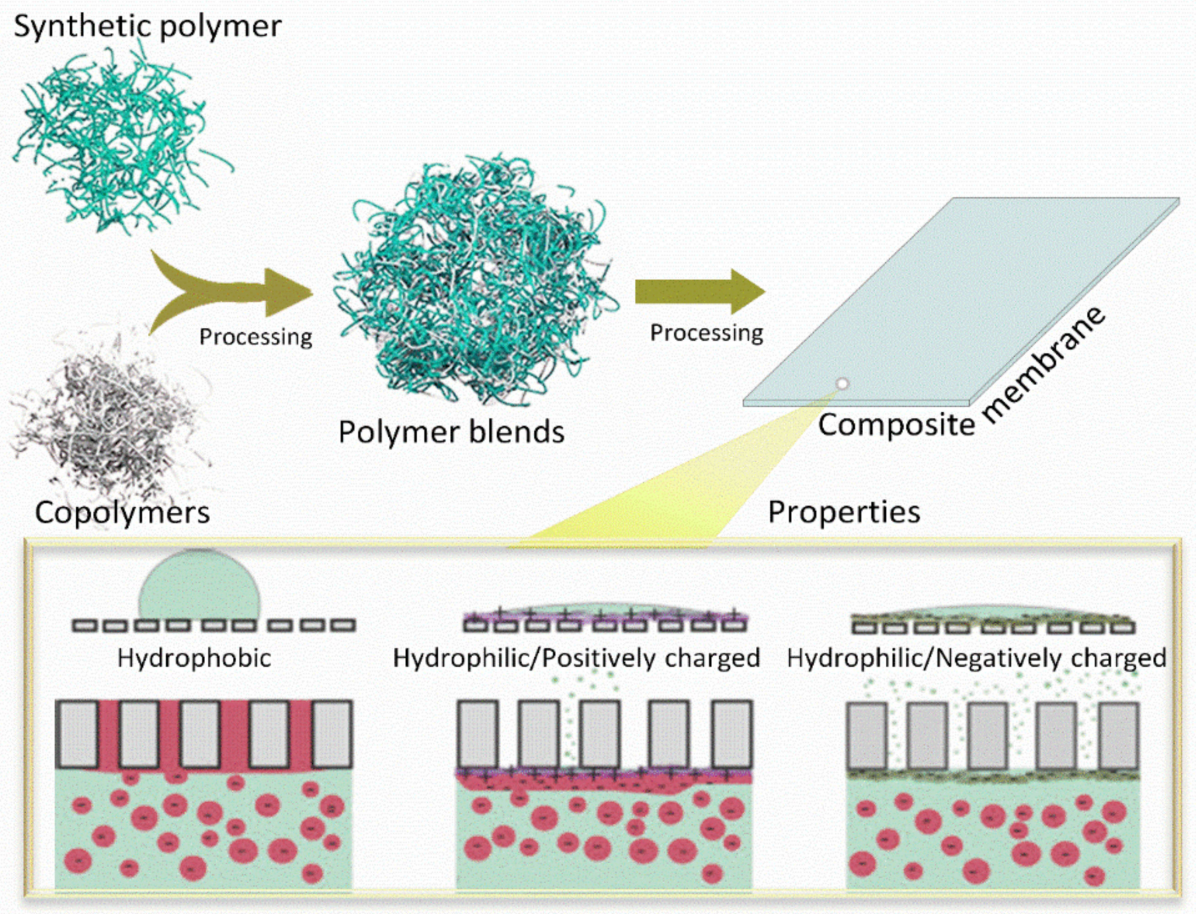

Figure 6. Schematic illustration of the preparation of PPSU membrane with superior properties via a typical polymer and copolymer blend system.

PPSU could be sulfonated using sulfonating agents such as sulfuric acid, sulfur trioxide, chlorosulfonic acid, and others. Attributable to the good miscibility, sPPSU could be blended with PPSU matrix or other polymers at any ratio. Arumugham and coworkers [49] developed modified PPSU UF membranes with higher fouling resistant properties. The membranes were treated sPPSU modifier. (Details are provided in Figure S1, Supplementary Materials). The membrane casting solutions were prepared and contained various amounts of sPPSU to entangle with the PPSU matrix. UF membranes were prepared using the phase inversion technique. It was found that the modified PPSU membranes showed a very low tensile strength value because of the influence of different content of sPPSU on the polymeric chain stacking of PPSU.

However, the hydrophilicity of the modified membrane was significantly increased due to the existence of an H-bond interaction between a water molecule and the polar sulfonic acid group. The latter resulted in their superior surface properties, higher flux, and antifouling properties with better protein rejection. Hartmann-Thompson et al. [112] synthesized a polyhedral oligosilsesquioxane (POSS) nanofiller with various groups and then used it as a hydrophilic polymeric additive in the preparation of sPPSU membranes. When blending into sPPSU, the modified sPPSU composite membranes exhibited proton conductivity in combination with improved dimensional stability, heat resistance, and mechanical strength (Figure S2).

Similarly, Yong et al. [67] synthesized a high free volumes polymer with intrinsic microporosity (PIMs) by the condensation polymerization process. Then, they blended it with sPPSU to develop a dense membrane (Figure S3). This membrane can be used for gas separation. They found that the sPPSU blend with PIMs can significantly improve the antiplasticization properties and gas separation performance. The latter can be attributed to the sulfonic acid groups in the sPPSU polymer matrix having strong molecular interactions with $\mathrm{CO}_{2}$ and $\mathrm{O}_{2}$ and forming hydrogen bonds. 
The PPSU membrane modification conditions were affected by the pore size and performance, such as PPSU/organic polymers membranes. Organic polymers accelerate the exchange rate between the solvent and the nonsolvent during the precipitation process. However, it strongly affects the size of the pores and the permeation rate. Organic polymers are often used as additives to blend with PPSU for improving membrane performance. Kiani et al. [66] modified the PPSU nanofibrous membrane by blending with polyethylene glycol (PEG) and prepared the membrane via the electrospinning process. The organic PEG polymers are soluble in water and may be eluded during application. A modified PPSU membrane showed the best behavior in all respects, including membrane porosity, hydrophilicity, and mechanical strength. Therefore, it was used for numerous practical applications. The PEG blending method also allowed improved antifouling properties. According to blending results, the addition of PEG to PPSU solution significantly increased the solution viscosity and caused a change in the shape of the nanofibrous beads from spherical to spindle-like. Similarly, the mechanical properties of the nanofibrous membranes were improved due to the blending of PEG. (Details are provided in Figure S4, Supplementary Materials). The latter acted as a plasticizer, facilitated the mobility of PPSU polymeric chains, and reduced the brittleness of the modified membrane. In this approach, the modified membrane capable of reducing the fouling tendency by means of hydrophilicity improvement was considered [10,147-149].

Furthermore, the influence of strength of PEG/PPSU polymer interactions has been highlighted experimentally by Feng et al. [21]. They found that when blending with PEG organic additive, the PEG could interact with sPPSU in the form of hydrogen bonding. Moreover, it increased the viscosity of the sPPSU solutions due to enhanced polymer interaction and entanglement. In addition, with an appropriate amount of PEG blended with sPPSU solution, the modified membrane possessed improved mechanical strength, higher hydrophilicity, and permeation properties as shone in Figure S5, Supplementary Materials. The authors observed that PEGs-rich sPPSU dope solutions experienced changes in dope viscosity caused by multiple factors. More specifically, PEG was a weak nonsolvent for the sPPSU molecules. Thus, when mixing with solvent, they decreased the solvent ability. The hydroxyl groups in PEG act as cross-linkers that connect sulfonic acid groups of the sPPSU polymer by hydrogen bonding. This blending process clarifies that the introduction of PEG into sPPSU blend solutions not only increases chain interaction and entanglement but also enhances the mechanical properties along with improving the membranes' fouling resistance.

Another interesting study considered blending of the different polymeric pore-forming agents PEG and PVP, and a surfactant Tween-80 (Liu and Li [30]). They studied the asymmetric PPSU UF flat sheet membranes prepared by a nonsolvent-induced phase separation method with enhanced antifouling properties. The addition of the PEG, PVP, and surfactant to the PPSU solution significantly modified the morphology of the polymer. The cross-sections of PPSU membranes prepared by a single pore-forming agent had a tendency to form macrovoid structures near the bottom surface layer [78]. At the same time, the pore size distribution on the top surface of the polymer pore-forming agent (PEG and PVP) was not uniform due to the high mutual affinity of solvent to water and additives. The latter led to the formation of macrovoid structures. When blending the PPSU with polymeric pore-forming agents and surfactant, the modified membranes were observed (Figure 7). They featured uniform structures in the cross-section and top surface.

Moreover, the pores were more effective at the top surface of modified PPSU membranes, which became small and uniform. It was also found that the filtration resistance decreased, while the flux recovery ratio increased, and the cake layer and pore plugging resistance decreased. Yin et al. [13] investigated the effect of PVP molecular weight and concentration on the blending with PPSU solution and the performance of modified PPSU membrane, including morphology, mechanical strength, tensile strength, molecular weight cutoff (MWCO), and permeation. The PPSU-PVP blend membrane showed good alkali resistance and higher water flux compared to the pure PPSU membrane. The latter was 
attributed to stronger antialkali and hydrophilic properties. The PVP with high molecular weight and concentrations had a greater effect on membrane morphology compared to the counterpart with lower molecular weight. The latter was due to the increase in blending solution viscosity and the polymer becoming thermodynamically stable. It resulted in delayed demixing followed by membrane structure shift from fingerlike to spongelike (Figure 8). Furthermore, it can be pointed out that the mechanical strength increased with appropriate PVP molecular weight $(360 \mathrm{kDa})$ due to suppressed formation of macrovoids. However, when the molecular weight of PVP was much higher (1300 kDa), the mechanical strength was significantly weakened. Gronwald et al. [96] synthesized a random poly (alkylene oxide) based on tri and multiblock copolymer additives by reacting hydrophobic PPSU blocks in a conventional process and then blending it with PPSU to fabricate hydrophilic flat sheet and single bore UF membrane for antifouling.
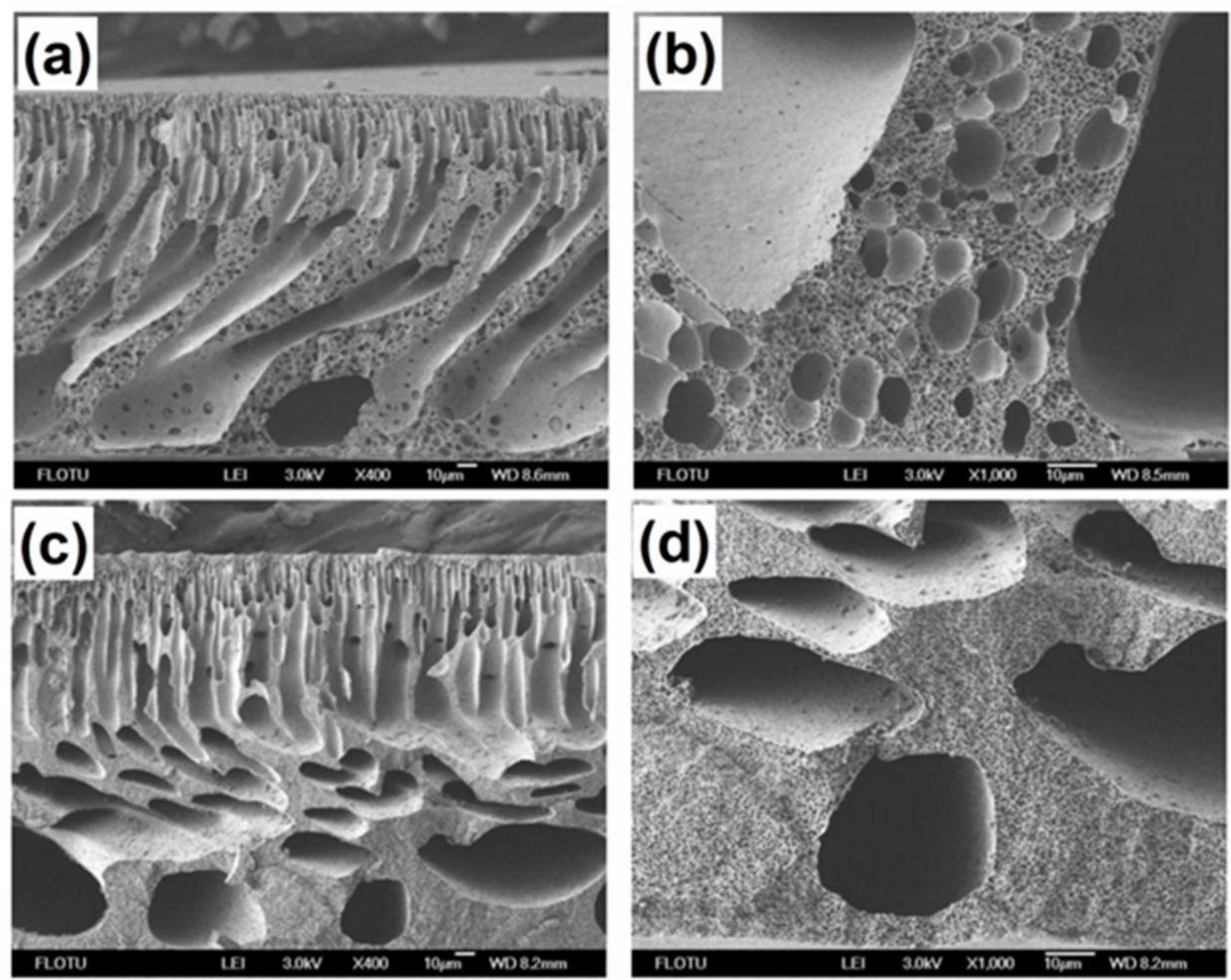

Figure 7. SEM photomicrographs of cross-sections of PPSU UF membranes prepared with: (a,b) PVP15000; (c,d) PEG-6000 as a polymeric pore-forming additives.

Polyimide is a representative of high-temperature engineering polymers in which the imide group is an important part of the molecule. The amide group is formed by a condensation reaction of an aromatic anhydride group with an aromatic amine. This group is responsible for forming incredibly strong and astoundingly heat and chemically resistant polymers [130]. Due to the superior properties of a polyimide polymer, it was often blended with different materials into binary blends and used for membrane fabrication. Jansen et al. [62] fabricated the PPSU/polyamide blend membranes with wet phase inversion induced by an immersion-precipitation technique for solvent-resistant nanofiltration applications. The organic solvents flux through the prepared membranes was increased by blending PPSU with polyimide. Moreover, the gas separation properties of the PPSU/polyamide blend membranes were improved. 

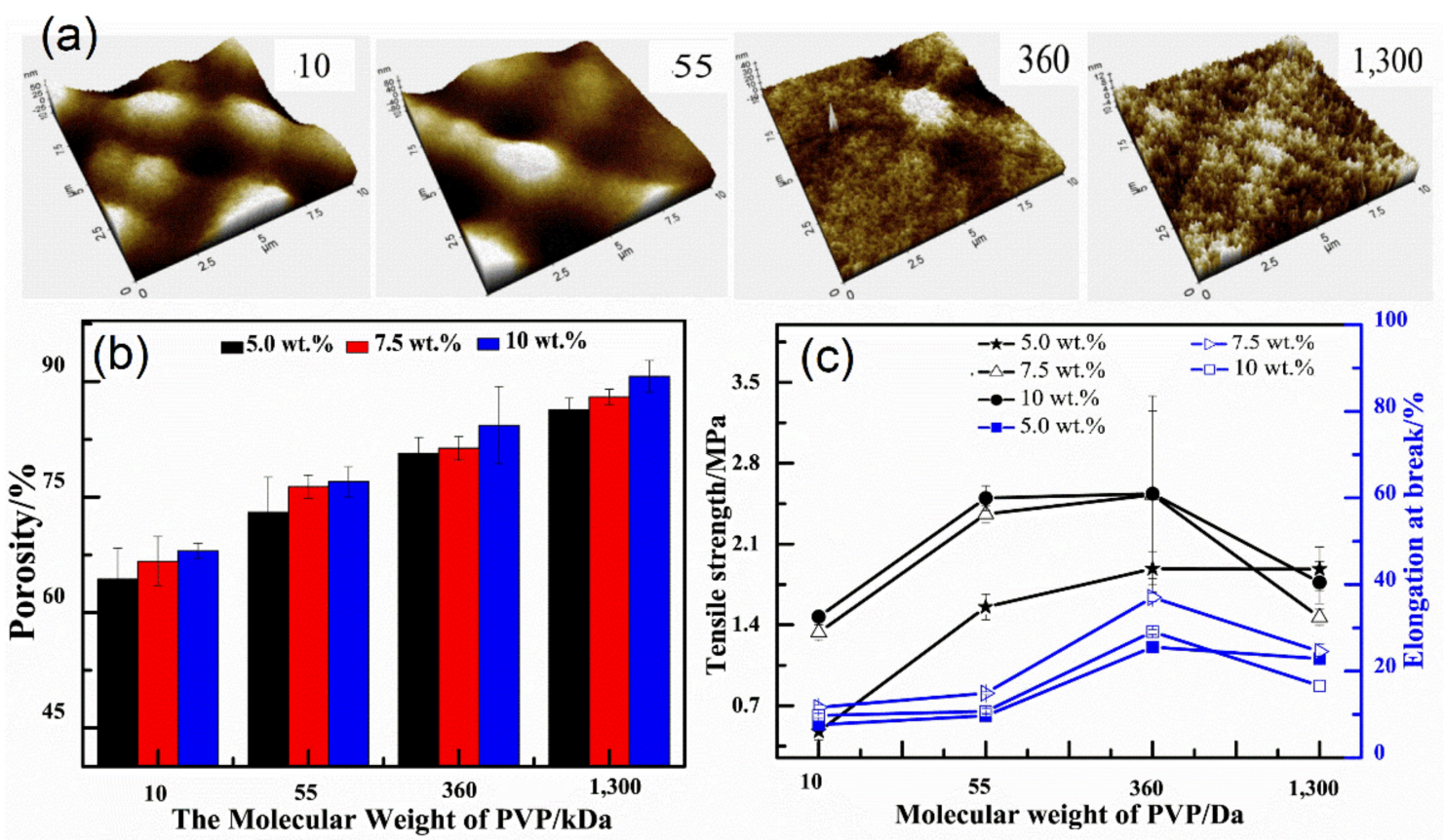

Figure 8. PPSU UF membranes with different molecular weight of PVP: (a) AFM images; (b) porosity; (c) tensile strength.

\subsection{Polyphenylsulfone Blended with the Nanomaterials}

Apart from introducing blends with polymers and copolymers, inorganic nanomaterials are another promising modifier of PPSU. The blending of inorganic materials with the PPSU matrix has become an attractive methodology for the improvement of polymeric membranes and thus has attracted researchers' attention in the recent decade $[41,97,150,151]$. Multiple studies were carried out on the development of nanocomposite PPSU membranes by the combination of inorganic nanoparticles. The incorporation of inorganic nanoparticles could produce a barrier that prevented free radicals from attacking the PPSU backbone. For example, the blended inorganic nanoparticles in the PPSU matrix have been reported to improve the polymer properties, mostly by: (a) enhancing the mechanical and thermal properties; (b) inducing some new functional properties into the membrane; (c) improving structural morphology; (d) enhancing the mass transfer; (e) increasing the larger effective membrane surface area and follow-on greater permeability; (f) improving the surface charge; (g) raising a membrane's hydrophilicity as well as antifouling properties. Up to the present time, various types of inorganic materials have been blended as additives in the PPSU matrix. These included graphene oxide, copper oxide, titanium dioxide, zinc oxide, magnesium oxide, zirconium oxide, silicon dioxide, activated carbon, carbon nanotubes, and metal-organic frameworks. As reported, the properly blended nanoparticles can facilitate the dispersion in a PPSU polymer solution and cause a possible rearrangement of nanoparticles in the membrane matrix (Figure 9).

Shukla et al. [152] made blends of PPSU with graphene oxide to fabricate a nanocomposite UF membrane with increased hydrophilicity. They showed that this method was effective because only a small weight percentage range of the nanoparticles was required to modify the PPSU membrane properties while maintaining the structural properties unaltered. As a result of less agglomeration, excellent nanoparticle dispersion in the membrane was achieved with optimized concentrations. The dispersity problem that occurred during the fabrication of nanocomposite membranes was solved by optimizing nanoparticle concentrations. Significantly higher water permeabilities were observed, along with higher negative surface charge properties. The latter was explained by antifouling properties, thereby improving the fouling resistance ability up to $58 \% \pm 3 \%$ (Figure S6, Supplementary Materials). 


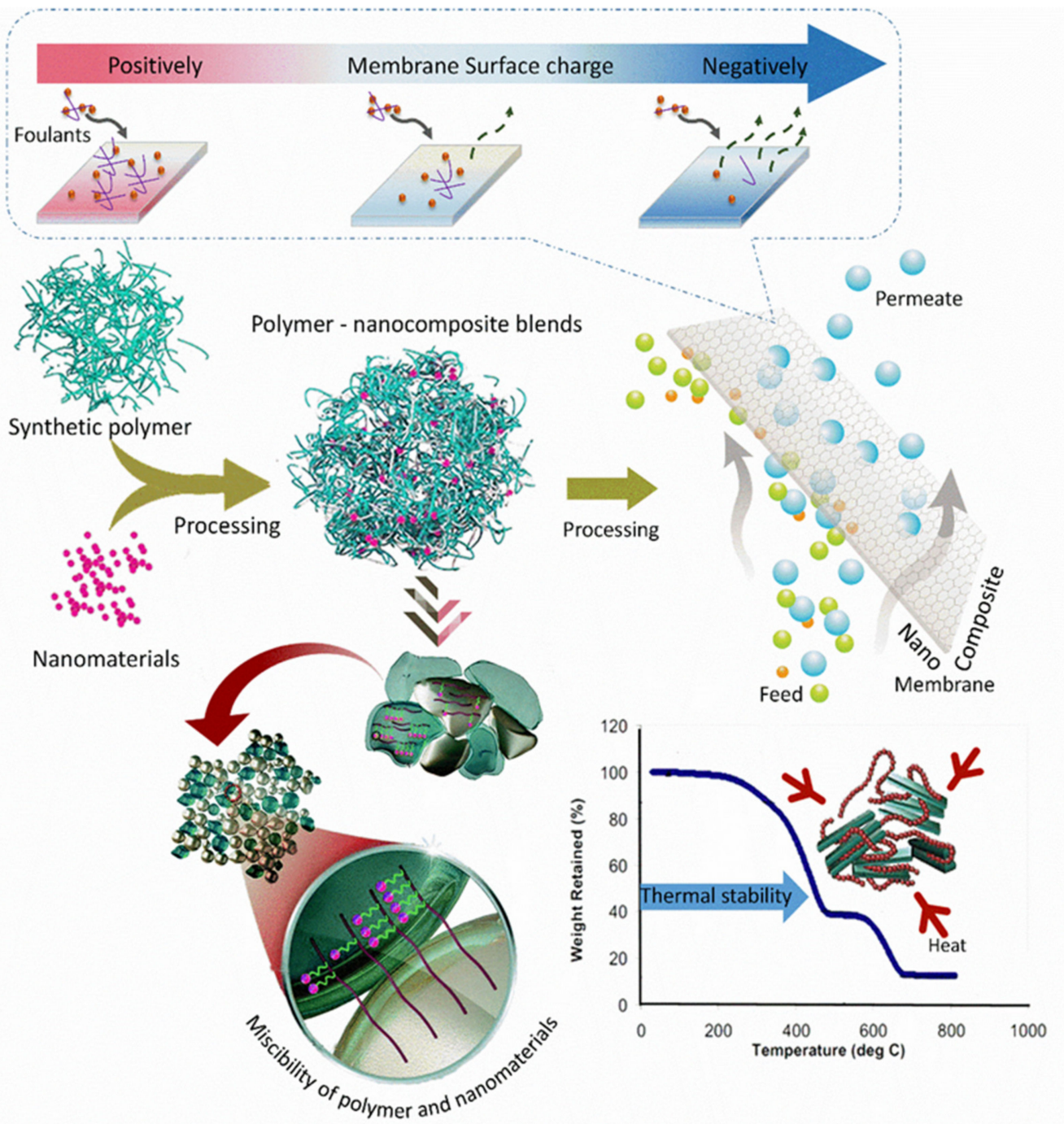

Figure 9. Illustration of the preparation of a PPSU nanocomposite membrane with higher surface and thermomechanical properties via a typical polymer and nanomaterial blend system.

Sani and coworkers [65] self-synthesized copper-1,3,5-benzenetricarboxylate $(\mathrm{Cu}-$ BTC) nanoparticles with different contents to blend with PPSU for improving methanol separation ability and nanofiltration performance. The $\mathrm{Cu}$-BTC particles were enriched at the blend membrane surface. By incorporating Cu-BTC particles, the performance of the blend membranes was significantly improved (Figure 10).

The membranes showed that the incorporation of $\mathrm{Cu}$-BTC with low loads tended to have a smaller molecular weight cutoff than that of PPSU. However, increasing the content of nanoparticles with PPSU led to a smaller surface pore size but better separation efficiency. The enhancement in membrane flux and dye-methanol separation at lower $\mathrm{Cu}$-BTC loadings could be ascribed to the good dispersion of the nanoparticles in the PPSU blends coupled with their improved interfacial contact with the polymer matrix. Then, they also fabricated organic solvent (methanol, ethanol, isopropanol, acetonitrile, ethyl acetate, n-hexane, and n-heptane) -resistant nanofiltration membranes using $\mathrm{Cu}$-BTC with a PPSU blend. The PPSU nanocomposite membrane exhibited acceptable durability and dye/methanol solution separation performance stability $[70,153]$. 

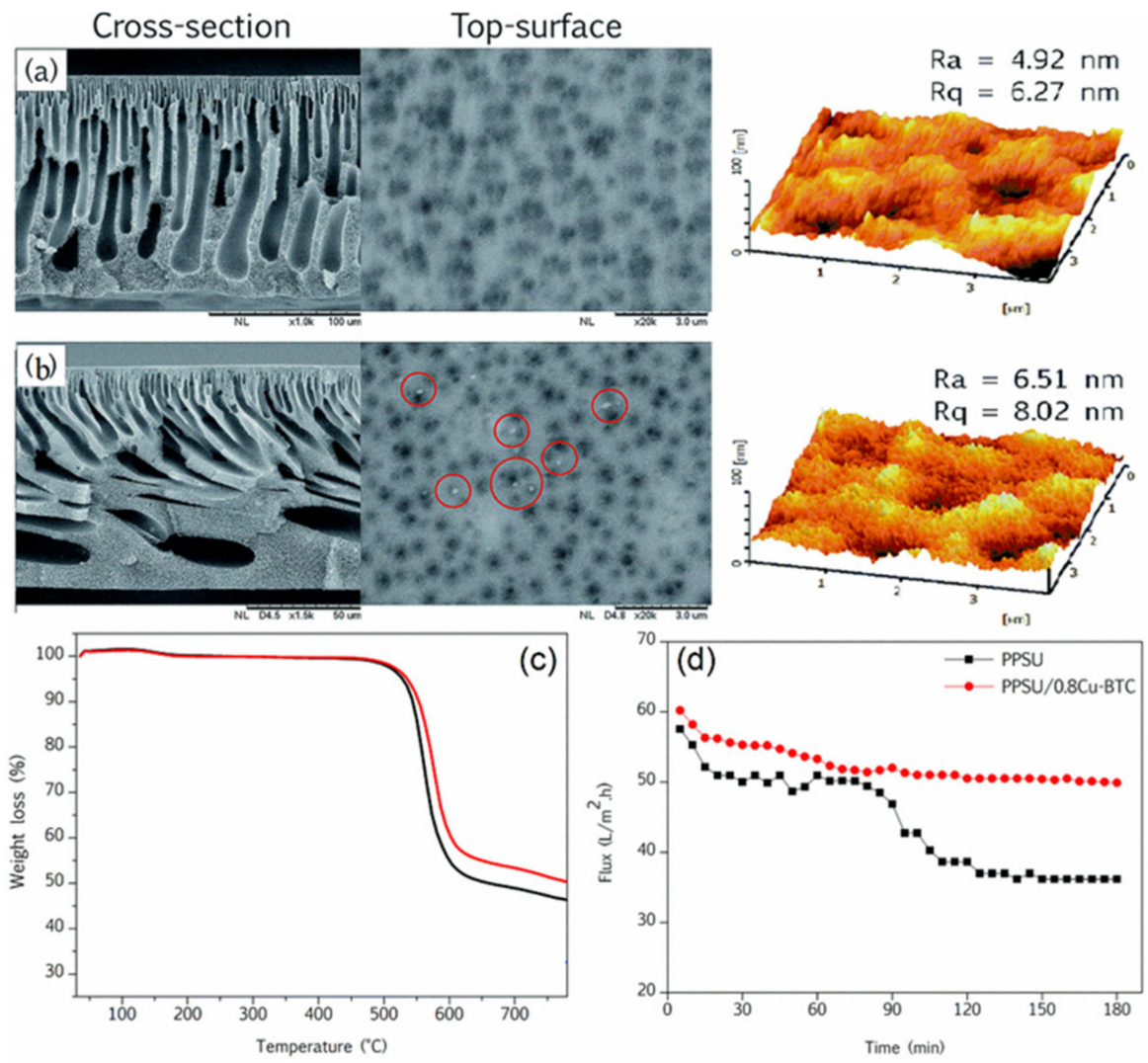

Figure 10. PPSU membranes embedded with Cu-BTC; SEM images of cross-section, top surface and 3D AFM images: (a) PPSU; (b) PPSU/Cu-BTC; (c) TGA curves; (d) flux profile membranes.

Functionalized activated carbon (FAC) and multiwall carbon nanotubes (MWCNTs) could be directly blended with PPSU to prepare membranes for improving the membrane separation. Saranya et al. [68] fabricated composite membranes from the blends of PPSU and FAC by the wet-phase-inversion method. The structural morphology of PPSU /FAC membranes clearly showed a composite structure with a porous sublayer. The results demonstrated that chemical modifications of nanoparticles resulted in better dispersion of nanoparticles in the membrane with reduced agglomeration. The dispersity problem that occurred during membrane fabrication was solved by modifying nanoparticles. Next, the hydrophilic PPSU /FAC composite membranes were evaluated for the adsorption of phenol and revealed that the smaller the blending of FAC in PPSU, the higher the adsorption of phenol. Thus, the better dispersion of minimal blending offers higher accessibility to adsorptive sites (Figure S7, Supplementary Materials).

Nayak et al. [94] prepared asymmetric mixed matrix ultrafiltration membranes from the blends of PPSU and MWCNTs to inspect the heavy metals separation efficiency from the aqueous media. By blending the MWCNTs in the PPSU matrix, the morphology of the fabricated membrane showed heterogeneous layers that consisted of a dense skin layer on top and a porous supportive sublayer and allowed significant improvement of surface roughness. Apart from the surface properties, the membranes featured better antifouling ability and exhibited good rejection performance for heavy metals. Shukla et al. [87] also modified the PPSU membrane by blending Ag-MWCNTs and the modified nanocomposite membranes. They showed good ion removal and antibacterial capacity due to the functional groups of additives. The Ag-MWCNT/PPSU nanocomposite membrane has been reported for potable water purification applications due to its excellent properties and relatively good compatibility. (Details are provided in Figure S8, Supplementary Materials).

A nanomaterial was blended with PPSU to prepare nanocomposite membranes. The nanocomposite membrane reduced biofouling abilities and better water fluxes. The possi- 
bility of bacterial attachment (biofouling) was associated with water transport and surface characteristics $[87,95,104]$. The casting solution composition, concentration, and inorganic salts all had an impact on the membrane filtration efficiency. The modified membrane was compared to a nanomaterial and the surface charge membrane with respect to their potential to inhibit bacterial growth and biofouling of a nanocomposite membrane. Shukla and coworkers [41] modified the PPSU UF membranes by the incorporation of carboxylfunctionalized graphene oxide using the phage inversion technique. The membrane characteristics for biofouling were tested in the presence of Gram-negative bacteria (E. coli and P. aeruginosa) and Gram-positive bacteria (S. aureus). It was found that the nanocomposite membrane inhibited the attachment, colonization, and biofilm formation of bacterial species. As a result, these modified membranes may be more resistant to biofouling.

A wide range of metal-oxide-based nanoparticles have a large surface area and specific functional groups and thus could be blended with PPSU to modify the PPSU membrane. The nanoparticles exhibit enhanced properties at a nanoscale level, and the PPSU matrix is used to hold the nanoparticles together. Blending nanoparticles with the PPSU polymer allowed for improved membrane properties, including morphology, thermal and mechanical properties, corrosion rate, oxidation resistance, and surface functional groups. D'1ez-Pascual and coworkers [63] and Dass et al. [77] investigated the effects of titanium dioxide $\left(\mathrm{TiO}_{2}\right)$ nanoparticles blended with PPSU and sPPSU to obtain antibacterial and antifouling membranes and found that hydrophilic groups were mostly concentrated at the membrane surface. The modified membrane revealed the existence of strong hydrogen bonding interactions between the sulfone group of PPSU and the hydroxyl moieties of the nanoparticles, which were homogenously dispersed within the polymer matrix without adding coupling agents. The attachment of nanoparticles and polymer matrix tailored the surface chemistry of the composite membrane by altering the morphology and water permeability. The approach of Kumar et al. [45,103] was used to fabricate hollow fiber membranes for the removal of arsenic from aqueous media. The authors have blended a binary zinc-magnesium oxide $(\mathrm{ZnO}-\mathrm{MgO})$ on cellulose acetate (CA) with PPSU as well as zirconium oxide $\left(\mathrm{ZrO}_{2}\right)$ with PPSU. The latter allowed evaluation of the affinity of the PPSU to the nanofiller and revealed significant enhancement in the overall performance of the membrane with water permeability and rejection. Arumugham et al. [69] selected a $\mathrm{MgO} / \mathrm{sPPSU} / \mathrm{PPSU}$ blend and a sequence of addition where the magnesium oxide $(\mathrm{MgO})$ nanoparticles were first mixed with sPPSU, and this composite was then mixed with PPSU. As a result, the castor oil/water emulsion separation and antifouling properties were improved. Another interesting blending method to quantify the PPSU interactions and relate them to the distribution of the silica nanoparticles was suggested by Dehban et al. [97]. They studied blends of a PPSU matrix with $\mathrm{SiO}_{2}$ and then fabricated the nanocomposite ultrafiltration membranes by a combined vapor induced phase separation and nonsolvent induced phase separation technique. The polymer concentration allowed the researchers to determine which range of nanoparticle concentration showed better performance. It showed the effect of $\mathrm{SiO}_{2}$ nanoparticle concentration on the low and high PPSU matrix concentrations in blend solution. While the PPSU concentration in the blend solution was low, the increase of $\mathrm{SiO}_{2}$ nanoparticle concentration brought about the lower fluxes. However, at high PPSU concentrations, the increase in the nanoparticle concentration resulted in an increase in permeate flux. Similar observations were made by Isloor et al. [89], who blended PPSU with nano tin oxide $\left(\mathrm{SnO}_{2}\right)$ and found an increase of hydrophilicity with $\mathrm{SnO}_{2}$ concentration. The rejection rate of mixed matrix hollow fiber nanocomposite membranes has improved.

Metal-organic frameworks (MOFs) blended with PPSU polymer allow enhanced general membrane performance, and thus various blending techniques for the preparation of PPSU composite membranes have been actively developed. In contrast to blending with the PPSU matrix, Xiao et al. [100] used as-synthesized MOF-CAU-1 nanoparticles as a filler and PPSU as a polymer matrix. The PPSU solution blending with different amounts of MOF-CAU-1 allowed fabricating a mixed-matrix membrane using immersion-precipitation 
and phase transformation techniques. The authors argued that the blending with MOFs resulted in a typical asymmetric membrane structure and higher surface roughness with nodular structure appearing on the surface. The abovementioned modified PPSU results illustrate that blending with MOFs can play a dominant role in pure water flux and antifouling performance. Recently, Shukla et al. [102] found that introducing zinc-based MOFs filler in PPSU blends led either to the increase or to the decrease in the performance of the membrane depending on the filler concentration. The presence of filler was shown to result in different compositions of the membrane due to the stronger interactions of the PPSU matrix with the zinc-based MOFs. The authors found that the surface charge and pure water fluxes of the membranes were much greater in the presence of filler (Figure S9, Supplementary Materials). Moreover, the water permeation and protein rejection were improved. Finally, the antifouling analysis confirmed that the membranes exhibited fewer tendencies for fouling.

\subsection{Polyphenylsulfone Blended with the Biopolymer}

Apart from introducing blends with polymers and copolymers, a number of interventions have been used to improve the polymeric membrane properties during their applications. One methodology implied creating such membrane modification via blending PPSU polymer with hydrophilic biopolymers. The benefit of blending with hydrophilic biopolymers is that modification takes place even within the PPSU membrane pores and not only on the surface. The naturally occurring biopolymer containing the different functional groups can be used to modify the PPSU hydrophilicity and surface structures. There is growing interest in polymer technology to use biopolymers as modifiers or as additives due to their biocompatibility, nontoxicity, and antimicrobial properties [127,154-158]. In recent studies by Alam et al. [74] the PPSU polymer blended with naturally occurring carrageenan biopolymer as an additive facilitated improvement in membrane porosity. The authors observed that the water-soluble carrageenan was unavoidable at the membrane surface after modification. It can be pointed out that carrageenan is a very promising modifier of PPSU polymer. In particular, it allows us to study the membrane properties and characterize it with contact angle, zeta-potential, porosity, mean pore diameter, and water permeability.

\section{Polyphenylsulfone Surface Modification}

The top selective layer plays a significant role in PPSU membrane performance. The membrane surface (top layer) properties can be correlated with the hydrophilicity/hydrophobicity, surface charge, and surface roughness/smoothness. These characteristics define the affinity of the membrane top selective layer toward the applications. Hence, numerous research efforts have been devoted to the modification of membrane surface properties using physical or chemical modification processes [159-162]. In a physical surface modification, the modifiers interacted with a top layer of the polymeric membrane surface and were attached by van der Waals attraction, hydrogen bonding, or electrostatic interaction [163-166]. This approach allowed long-term operation. In a chemical surface modification, the modifiers are connected to the polymeric membrane surface through covalent bonding. In this process, the polymeric chain was activated by chemical reaction or high-energy radiation and followed by the addition of the modifier. Thus, the membrane bulk was not significantly affected. However, the membrane surface properties were significantly improved and demonstrated better chemical and structural stabilities [21,83,167-169]. We further review the techniques of physical and chemical surface modification of the PPSU membrane surface in Figure 11. 


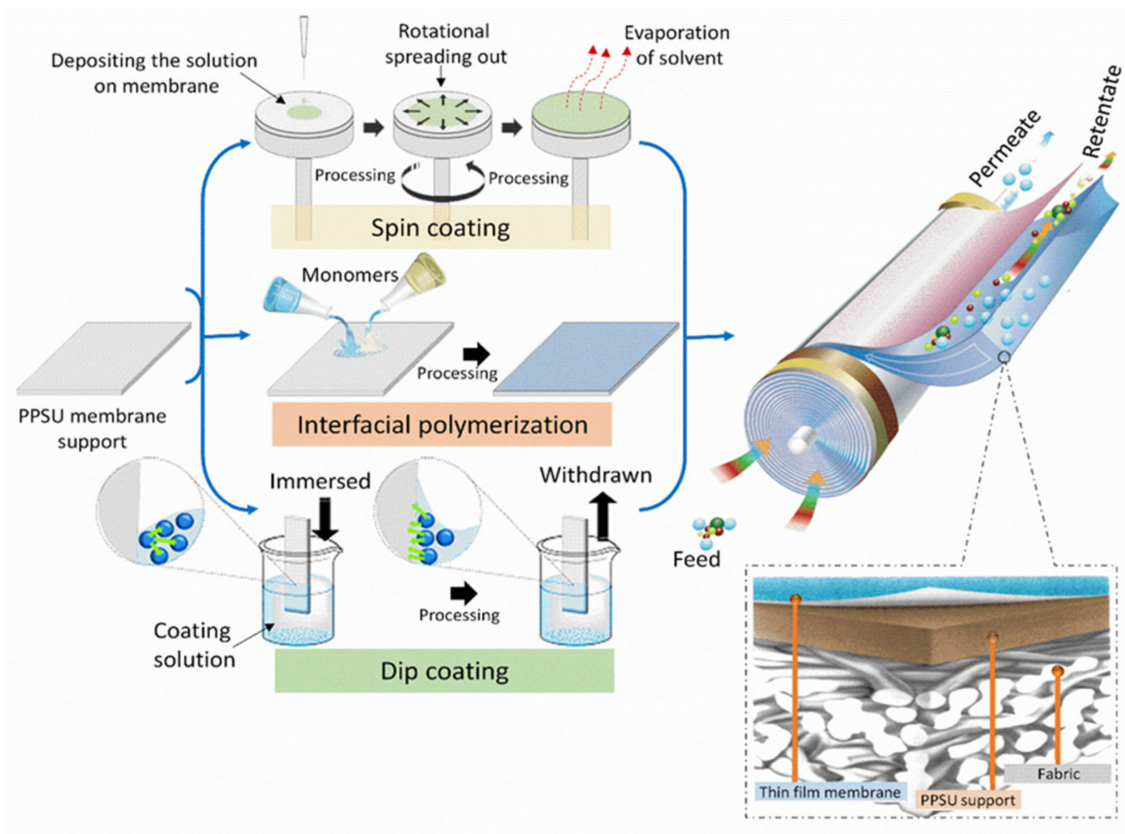

Figure 11. A schematic of the PPSU surface modifications using physical and chemical surface modification techniques.

\subsection{Physical Modification}

Physical surface modification of PPSU membranes were investigated by surface coating or surface adsorption. Surface coating is a convenient and inexpensive method to modify the membrane surface. It has been generally used in membrane industries for largescale production $[147,159,170]$. This method involves two general steps. First, the coating material is sprayed as a liquid or laid down as a surface of the porous membrane, which is then covered and bonded to the surface. Second, we evaporate the residual solvent/water at a moderate temperature. The surface-coated layer can be controlled by adjusting the operating parameters. Surface coating is done by a relatively simple process that creates a functional surface layer on the membrane surface. Surface coating is widely used elsewhere. For instance, Çalhan et al. [36] coated the polydimethylsiloxane (PDMS) with PVP additive and with two fumed silica fillers onto a PPSU support layer membrane surface, followed by cross-linking PDMS to improve their separation property. The membrane surface hydrophobicity increased with the spreading of PDMA chains over the PPSU membrane surface. Moreover, the addition of silica fillers with PDMA to the active layer allowed a further increase of hydrophobicity. Additionally, an increase in the PDMS thickness significantly affected the flux and the separation rate. For the separation performance, the butanol fluxes increased with increasing butanol concentrations in feed, while the separation factor showed an opposite trend for PDMS with additives. The membranes with PDMS and silica particles embedded into the support layer slightly increased the separation. At the same time, fluxes were not affected compared to the pure PDMS-coated membrane.

Tashvigh et al. [79] investigated the effect of coating of ionically cross-linked hyperbranched polyethylenimine (HPEI) on the sPPSU membranes. This surface modification method included several stages. First, the dope solutions were prepared by dissolving sPPSU and HPEI in DMF/THF. Next, they were used to cast films on a glass plate and develop the sPPSU/HPEI membrane. Afterward, the HPEI in water or ethanol solution was coated on the prepared sPPSU/HPEI membrane to enhance the rate of the ionic crosslinking reaction and seal the membrane defects under different conditions. Figure S10 (Supplementary Materials) shows the ionic cross-linking reaction between sPPSU and HPEI polymers. 
The authors applied the dip coating and pressure-assisted coating methods. In the dip coating, the membrane was immersed in HPEI-water or ethanol solution for 30 min and washed with water to remove any excess HPEI. For the pressure-assisted coating approach, the membrane was placed in a dead-end permeation cell, and the HPEI-ethanol solution was filtrated for $30 \mathrm{~min}$ under 5 bar. Next, pure water filtration for $30 \mathrm{~min}$ was used to remove the excess HPEI and ethanol from the surface. The surface coating procedures used dip- and pressure-assisted coating. The surface-coated membranes demonstrated good chemical stability in ethanol and isopropanol. In addition, coated membranes were more stable in terms of pure ethanol permeability and rejection of different dyes.

Recently, Alam and coworkers [104] performed another physical coating study on the surface of the PPSU substrate membrane with polyaniline (PANI) and consisting of a thin-film nanofiltration membrane. In their method, the liquid PANI mixture (ammonium persulfate served as the oxidant, and $\mathrm{HCl}$ was used as a doping agent) was first coated on the surface of the PPSU substrate membrane using the pouring method and then kept for the polymerization process (Figure 12). The PANI coating significantly reduced the membrane surface roughness with a substantial change in the lower contact angle. Moreover, the polyaniline thin-film coated PPSU membrane had a less negative surface charge compared with the PPSU substrate membrane. However, the backbone of the PANI corresponding to the hydrophilic region extended to a water phase and repelled various foulants in feed water. Experiments using a dye separation and antimicrobial activity (such as Escherichia coli (E. coli) and Staphylococcus aureus (S. aureus) showed that the PANI-surface modified membrane improved organic methylene blue dye rejection and antimicrobial capability.

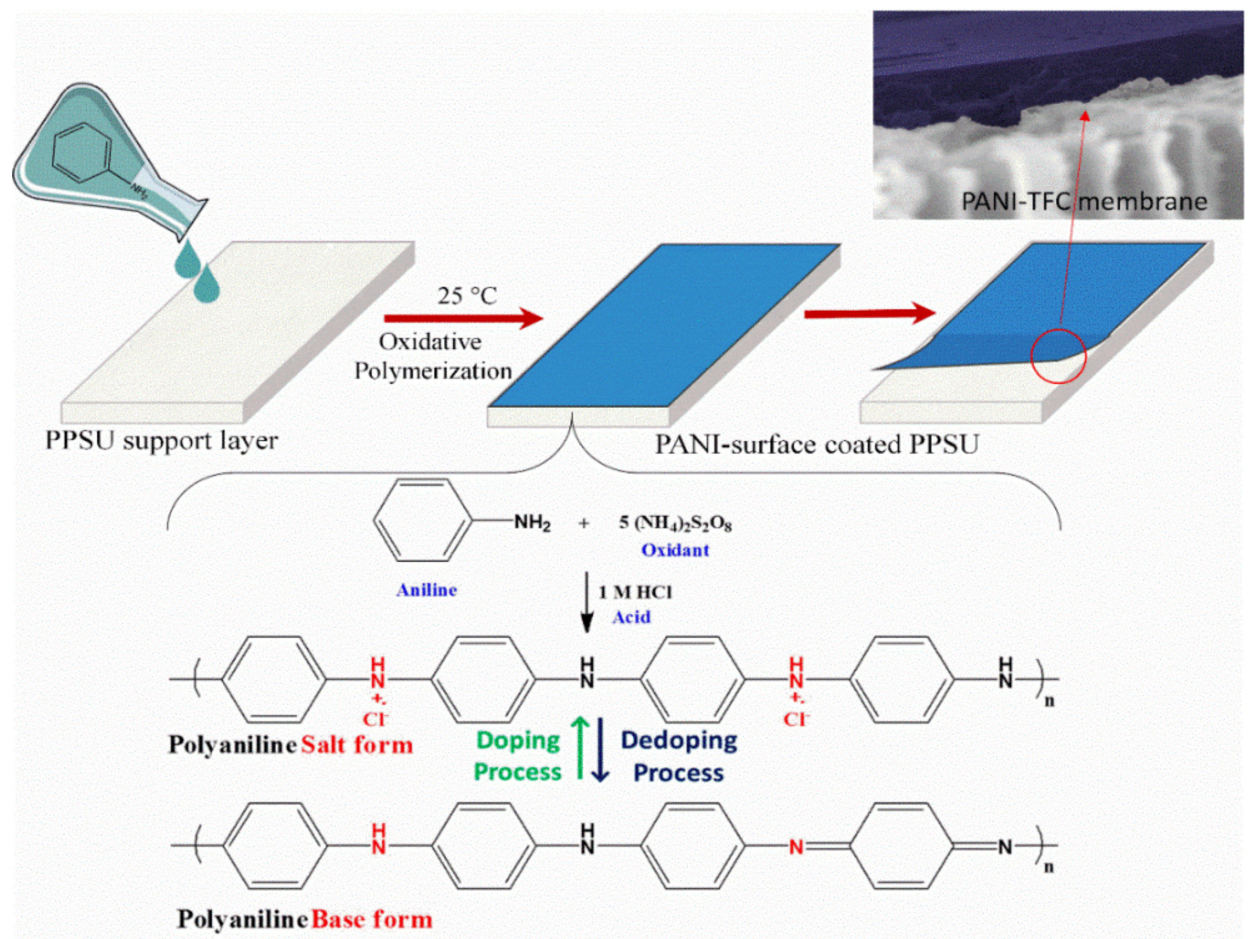

Figure 12. PANI-surface Polyphenylsulfone membrane surface coating via the chemical oxidation of monomeric aniline.

\subsection{Chemical Modification}

PPSU membrane surface modification has been considered as a suitable process to improve the surface properties of the membranes without affecting bulk properties. The chemical surface modification includes multiple processes such as plasma treatments, thermal-induced lamination, UV-induced grafting, interfacial polymerization, and others. These processes are commonly used due to their relative simplicity, high density, and wide-ranging monomers. Moreover, these monomers can be polymerized via cova- 
lent bonding interactions between the polymer chains with new functionality and the membrane surface (Figure 13). The latter can produce membrane surfaces with desirable physicochemical properties.
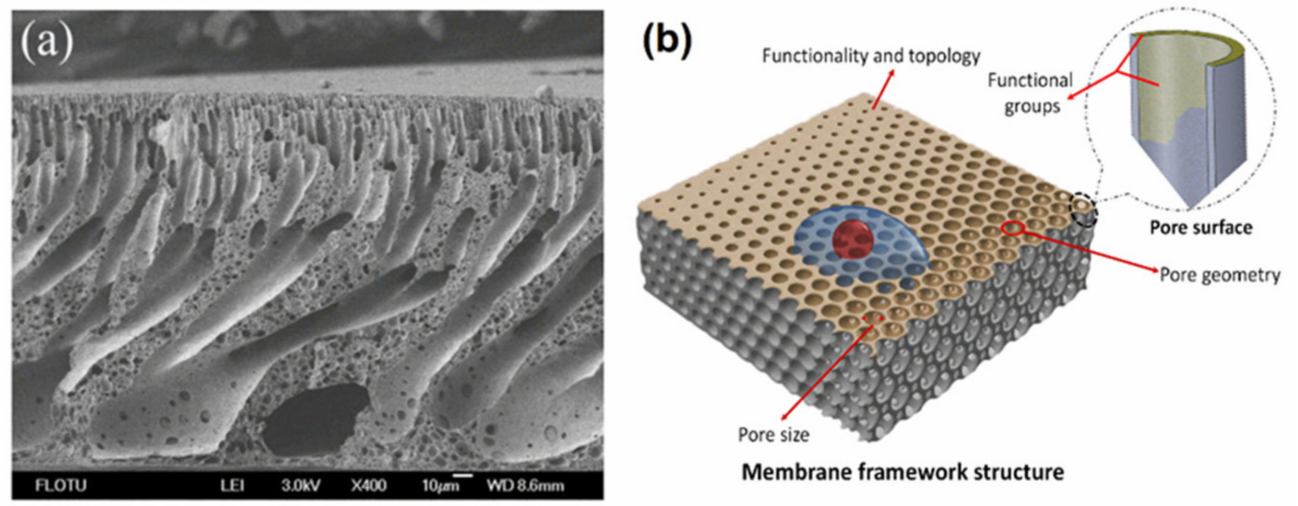

(c)
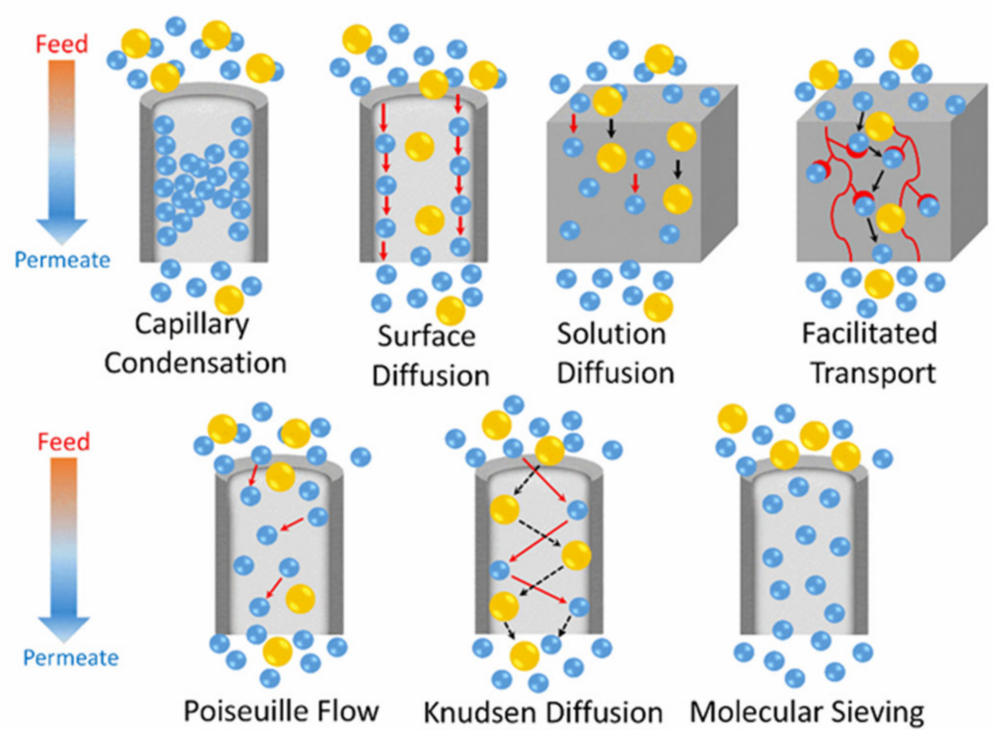

Figure 13. (a) SEM image of manufactured integrated asymmetric porous membrane; (b) schematic representation of pore size, pore geometry, pore surface, and structure of porous polymers; (c) schematic illustration of foremost transport mechanisms.

The plasma treatment has been widely used to achieve hydrophilic surfaces throughout the membrane structure. Plasma treatment has several advantages, including waste-free processes, fast reaction time, and high flexibility [171-175]. The plasma treatment process only requires the use of a lower degree of ionization and is usually referred to as a cold plasma process $[176,177]$. It introduces the different functional groups on the membrane surface with the variation of plasma treatment parameters such as chemical properties, power, and flow rate of the plasma gas and precursors along with treatment duration. Wang et al. [91] modified an electrospun PPSU nanofiber membrane using heat and plasma treatments. Thermal treatment results revealed that the mechanical properties of the modified membranes were affected, depending on the treatment. They showed that the thermal treatment transformed a loose nonwoven nanofiber structure into a robust interconnected PPSU network. Thus, an increase in both stress and strain was achieved. Moreover, the plasma treatment can be used to improve the wettability of the membrane surface. The low-pressure plasma-treated membrane surface turned superhydrophilic. In another work, Norrman and coworkers [11] carried out the modification of electrospun PPSU nanofibrous membranes via two different types of plasma. First, they applied low-pressure microwave plasma and then used atmospheric-pressure coplanar barrier discharge to control the sur- 
face chemistry and optimize hydrophilicity. The composition of chemical anchor groups for plasma-treated PPSU was monitored by X-ray photoelectron spectroscopy. They showed that the atmospheric-pressure plasma treatment provided subtle oxidation. Moreover, the low-pressure plasma provided significant oxidation that resulted in PPSU nanofibrous surfaces with very high hydrophilicity.

Thermal-induced lamination is a simple way to modify the PPSU membrane surface. Recently, Kiani et al. [147] modified a PPSU porous support surface via a thermally-induced lamination. In this approach, the nanofibrous support was immersed in the water bath containing the floating PPSU thin film. Subsequently, moving the support upward and toward the thin film, it was taken out of the water while the thin film was placed on the surface of nanofibrous support. The acquired membranes were further heated to induce the adhesion of fibers and the addition of the thin film and the nanofibrous support. Heat treatment was carried out in an oven at $245^{\circ} \mathrm{C}$ for one hour. The efficiency of the modified PPSU membranes was increased in pure water flux and steady permeate flux without sacrificing the rejection rate.

One more approach to modify the PPSU membranes is UV-induced grafting. It is attractive due to its simplicity and low cost. Additional advantages include the possibility of being applied to existing membranes and further functionalizing through postreaction [178]. Moreover, a wide range of monomers can be grafted. UV-induced grafting requires a low temperature and mild reaction conditions. Zhong et al. [58] applied the UV-induced grafting method for the first time to modify sPPSU membranes. It was highlighted that the effects of UV-initiated reactions onto properties of sPPSU membranes would mostly depend on the membrane structure and surface properties. The authors used the two different types of positively charged grafting monomers: (2-(methacryloyloxy) ethyl) trimethyl ammonium chloride and diallyldimethylammonium chloride. It is worth noting that after the UV-induced grafting, the morphology of the membrane top surface and selective layer thickness changed significantly. The slow change from a dense to the porous substructure with no signs of delamination demonstrated strong covalent chemical bonding between the sPPSU of the substrate and the vinyl monomers. In addition, the longer the UV exposure was, the thinner the membrane selective layer formed. The latter was due to the existence of an additional unsaturated double bond on diallyldimethylammonium chloride monomer that resulted in significantly improved separation performance.

The interfacial polymerization process is used to modify a PPSU membrane surface because of its low cost, availability, resistance to compaction, relatively high hydrophilicity, and chemical tolerance of the surface to a wide range of $\mathrm{pH}[100,179,180]$. The surface modification process involves two monomers and includes several steps. First, a porous PPSU support is soaked in an aqueous solution of an m-phenylene diamine (MPD). Second, the amine-impregnated PPSU membrane is immersed in a solution of trimethyl chloride (TMC) in hexane. Finally, the PPSU membrane is cross-linked by performing heat treatment. The membrane modification via interfacial polymerization process is shown in Figure 14. Based on this surface modification process, the various factors affecting modified membrane surface properties were identified. These included structural morphology, posttreatment conditions, solvent type, the concentration of monomers, reaction time, and reaction curing temperature.

Liu and coworkers [59] investigated the separation performance for sulfonated thinfilm composite NF membrane fabricated via interfacial polymerization. First, the surface of the PPSU membrane was pretreated with oxygen plasma to increase adhesion properties regardless of the material being used. Moreover, it resulted in the enhancement of the physical adsorption of sulfonated aromatic diamine monomers. Next, interfacial polymerization was performed. It was done at the microporous PPSU support membrane using two types of sulfonated aromatic diamine monomer, namely, 2,5-bis (4-amino-2-trifluoromethylphenoxy) benzene sulfonic acid and 4,4-bis (4-amino-2-trifluoromethylphenoxy) biphenyl4,4-disulfonic acid. Moreover, piperazine (PIP) with TMC was also used. The thin film formed at the PPSU support under the optimum condition showed an increase in water flux. 
In particular, surface hydrophilicity was enhanced by the presence of sulfonated aromatic diamine monomers without compromising the rejection. Widjojo et al. [61] modified the surface of the thin-film composite of a sPPSU supporting membrane via interfacial polymerization process using an MPD and TMC. The authors managed to enhance the performance of forward osmosis membrane applications. The thin layer morphology of the membrane PA surface had a spongelike structure without the formation of macrovoids. The latter provided better mechanical stability for the sPPSU membrane in the long-term perspective. The polyamide (PA) skin layer of the modified sPPSU membrane significantly improved the hydrophilicity and allowed it to achieve water flux under pressure-retarded osmosis mode. Golpour et al. [81] modified the PPSU-graphene oxide (GO) support layer to make a thin-film nanocomposite membrane by interfacial polymerization with PIP and TMC monomers. It was observed that embedment of nanoparticles (MOF) into a PIP monomer during interfacial polymerization significantly changed the membrane surface chemistry and morphology, leading to an improvement of hydrophilicity, surface charge, thermal stability, and mechanical strength. It should also be noted that the surface modification with nanoparticles affected membrane pore size and pore size distribution [76]. Moreover, the surface-modified membrane exhibited remarkable improvement in the antifouling capability and excellent long-term stability.
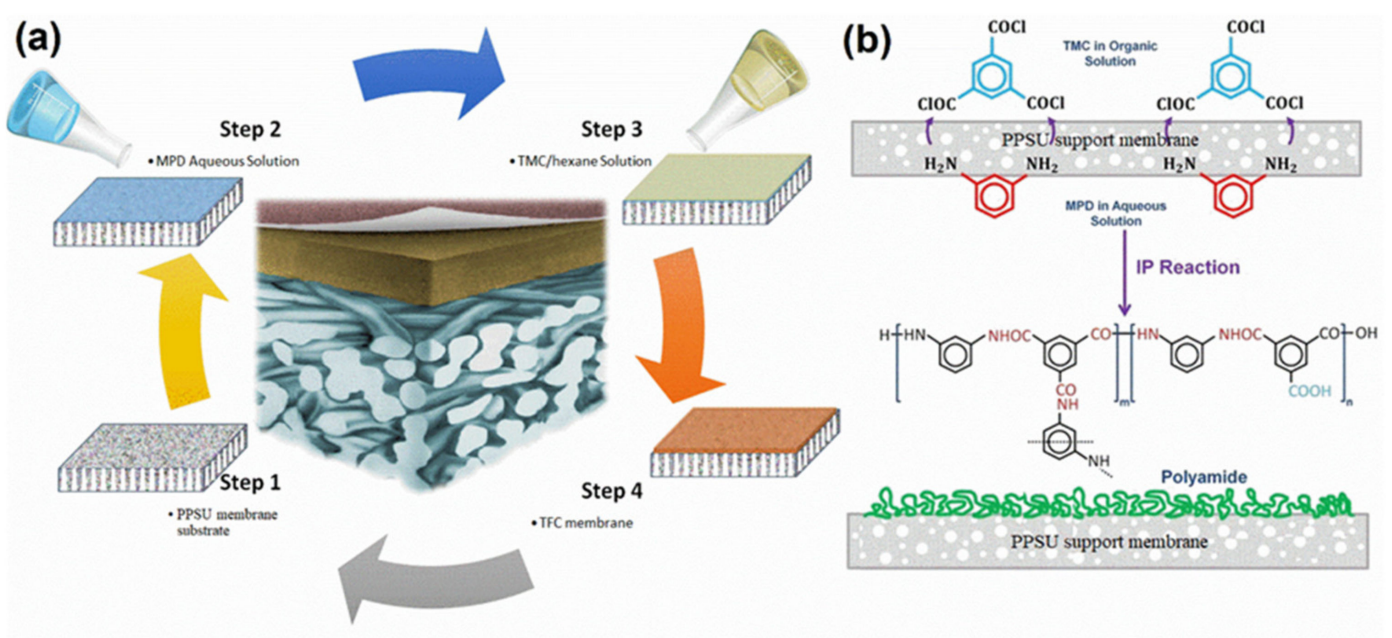

Figure 14. PPSU membrane surface modification schematic diagram: (a) steps in the modification process; (b) interfacial polymerization reaction mechanisms during the formation of the TFC layer.

Recently, Shukla et al. [181] have studied the desalination performance and chlorine resistance of thin-film nanocomposite membranes incorporating Zn-MOFs synthesized by interfacial polymerization over PPSU support membranes with amines such as trimesoyl chloride and phenylenediamine. The nanocomposite polyamide layer formed over the PPSU supports showed enhanced salt-rejecting properties with a comparatively lower salt permeation rate. Moreover, the membranes demonstrated significant water stability during filtration and chlorine resistance after a chlorine-soaking test due to the superior compatibility between the polyamide and Zn-MOFs on the PPSU supports.

\section{Conclusions and Future Prospects}

This review article has summarized up-to-date methods used for the modification of PPSU membranes. The modification methods vary with the materials used and the processes applied. These factors influence membrane stability and functionality. There are three main approaches for the modification of PPSU membranes: (1) bulk modification; (2) blending; and (3) surface modification. Based on these methods, the modified PPSU membranes with unique properties can be directly obtained.

As stated above, bulk modification and blending are among the most used methods. Bulk modification can include amination and chloromethylation. However, the most fre- 
quently used method is sulfonation. The sulfonation can be carried out through sulfonating modifier agents by the accumulation of sulfonic groups at the aromatic backbone of PPSU without polymer chain degradation. Moreover, it is very important to select reactive modifier agents that have high compatibility with the PPSU polymer matrix to avoid negative effects on the properties of the membrane. Doing so allows the sulfonation of bulky groups in the polymer chain structure, placement of such groups, and provides more flexibility to the polymer backbone. Blending is another promising approach to PPSU modification. It is relatively simple and has been often used with inexpensive materials to obtain superior characteristics. However, it has limited applicability due to immiscibility with hydrophilic and hydrophobic materials. The commercially available and synthesized biopolymers, organic and inorganic, have been widely blended directly with the PPSU matrix. As a result, the developed membranes possessed specific intrinsic chemical, mechanical, and physical properties. Polymeric additives such as carrageenan, PEG, and PVP are well known as pore formers. Moreover, they can enhance the characteristic asymmetric structure of membranes developed in the phase inversion process. With the same motivation, the organic and inorganic blending materials such as PEI, SPEEK, MOFs, $\mathrm{ZnO}, \mathrm{TiO}_{2}$, and $\mathrm{CNTs}$, and others have been proposed to enhance surface charge, improve hydrophilicity, modify pore structure, and add antibacterial capability to metal-based inorganic materials. Among the newly arisen inorganic additives, PPSU blends with GO are of superior functionality and permeability and can overperform the traditional PPSU polymers.

The performance of existing PPSU membranes can be improved through surface modifications, including physical or chemical modification processes. Surface modification may take place by bringing specific moieties via the surface-coating, plasma treatment, thermal-induced lamination, UV-induced grafting, interfacial polymerization, and other methods. Many of these surface modification methods have limited applicability due to high cost, complicated operation procedures, or difficulty in scaling up. In contrast, the interfacial polymerization method is widely used in commercial membrane production. Compared with surface-coating, plasma treatments, and UV-induced grafting, interfacial polymerization is a more promising approach. In particular, it allows achieving covalent linkage between membrane surface and modifiers. Membrane surface modification, either by physical or chemical processes, generally leads to additional resistance due to active layer formation after modification. The latter slows water permeation through the membrane active layer and decreases water permeability. Hence, the surface-modified membrane active layer should be thin, and the trade-off of flux reduction and surface properties should be optimized and balanced with modification conditions.

In the last decade, tremendous progress has been made in PPSU membrane modification to improve its surface properties. However, there are some challenges remaining for the future industrial applications of PPSU membranes. It is worth noting that developing 'ideal' methods for surface modification of membranes is a relatively challenging task. It is attributed to the inevitable compromise between exceptional physical and chemical properties and the possibility of long-term commercial applications. An in-depth understanding of the surface structure-property relationship between the membrane surface and modifiers during cross-linking is essential. Not only flat-sheet membranes, but also hollow fiber membranes, can be modified with this method. In part, this problem can be tackled using transport models and numerical simulations. Moreover, the polymer blend can be further improved to combine with other modifiers such as biomolecules and inorganic nanofillers through proper compositions. Innovations will influence the development of better membrane systems that eliminate the trade-off effect and are suited for long-term and commercial applications.

Supplementary Materials: The following supporting information can be downloaded at: https: / / www.mdpi.com/article/10.3390/membranes12020247/s1, Figure S1: Chemical structure of sulfonation reaction of polyphenylsulfone, prepared membranes mechanical strength, and their crosssectional morphological images of (a) PPSU, (b) sPPSU; Figure S2: The prepared sPPSU/sPOSS membrane (a) freeze fracture SEM cross-section image, (b) TEM image, and (c) dynamical mechanical 
strength properties; Figure S3: SEM image of membranes for gas separation (a) sPPSU, (b) PIM1/sPPSU; Figure S4: SEM images of the fibrous membrane surfaces with respect to the PPSU with PEG concentration in the electrospinning solution (a) $0 \mathrm{wt} . \%$; (b) $2 \mathrm{wt} . \%$; (c) $5 \mathrm{wt} . \%$; and (d) $10 \mathrm{wt} . \%$; and mechanical properties and water contact angle; Figure S5: SEM images of the sPPSU membranes surface and cross-section, water contact angles, and filtration performance with PEG concentration; Figure S6: PPSU/GO-based blended membranes (a) AFM and SEM images of PPSU; (b) AFM and SEM images of PPSU/GO; and water contact angle, surface zeta potential as a function of $\mathrm{pH}$, mechanical properties using tensile tests, and time-dependent fluxes of pure water, and BSA protein; Figure S7: Modified membranes (a) cross section, top surface SEM images and 3D AFM images; (b) rejection efficiency; and (c) flux recovery and fouling resistance ratio; Figure S8: PPSU embedded with Ag-MWCNT membranes: 3D AFM images, low and high magnification SEM images, and (a) zeta potential as a function of $\mathrm{pH}$; (b) contact angle and porosity; Figure S9: Modified PPSU and PPSU/Zn-MOF membranes: (a and b) surface and cross-section images; (c) zeta potential versus $\mathrm{pH}$; and (d) pure water hydraulic permeability; Figure S10: The ionic cross-linking reaction between sPPSU and HPEI at the membrane surface.

Author Contributions: Conceptualization, A.K.S. and J.A.; methodology, A.K.S.; formal analysis, M.A.; investigation, A.K.S.; resources, J.A.; writing-original draft preparation, A.K.S.; writingreview and editing, A.K.S. and J.A.; visualization, M.A.; supervision, J.A. and M.A. All authors have read and agreed to the published version of the manuscript.

Funding: The authors extend their appreciation to the Deanship of Scientific Research at King Saud University for funding this work through research group no. RG-1439-085.

Institutional Review Board Statement: Not applicable.

Informed Consent Statement: Not applicable.

Data Availability Statement: Not applicable.

Acknowledgments: The authors thank the Deanship of Scientific Research and RSSU at King Saud University for their technical support.

Conflicts of Interest: The authors declare no conflict of interest.

\section{References}

1. Decker, B.; Hartmann-Thompson, C.; Carver, P.I.; Keinath, S.E.; Santurri, P.R. Multilayer sulfonated polyhedral oligosilsesquioxane (S-POSS)-sulfonated polyphenylsulfone (S-PPSU) composite proton exchange membranes. Chem. Mater. 2010, 22, 942-948. [CrossRef]

2. Di Vona, M.L.; Sgreccia, E.; Licoccia, S.; Khadhraoui, M.; Denoyel, R.; Knauth, P. Composite proton-conducting hybrid polymers: Water sorption isotherms and mechanical properties of blends of sulfonated PEEK and substituted PPSU. Chem. Mater. 2008, 20, 4327-4334. [CrossRef]

3. Park, A.M.; Turley, F.E.; Wycisk, R.J.; Pintauro, P.N. Electrospun and cross-linked nanofiber composite anion exchange membranes. Macromolecules 2014, 47, 227-235. [CrossRef]

4. Singh, S.P.; Li, Y.; Zhang, J.; Tour, J.M.; Arnusch, C.J. Sulfur-Doped Laser-Induced Porous Graphene Derived from PolysulfoneClass Polymers and Membranes. ACS Nano 2018, 12, 289-297. [CrossRef] [PubMed]

5. Di Vona, M.L.; Sgreccia, E.; Tamilvanan, M.; Khadhraoui, M.; Chassigneux, C.; Knauth, P. High ionic exchange capacity polyphenylsulfone (SPPSU) and polyethersulfone (SPES) cross-linked by annealing treatment: Thermal stability, hydration level and mechanical properties. J. Memb. Sci. 2010, 354, 134-141. [CrossRef]

6. Zhu, X.; Zhou, Y.; Hao, J.; Bao, B.; Bian, X.; Jiang, X.; Pang, J.; Zhang, H.; Jiang, Z.; Jiang, L. A Charge-Density-Tunable Three/Two-Dimensional Polymer/Graphene Oxide Heterogeneous Nanoporous Membrane for Ion Transport. ACS Nano 2017, 11, 10816-10824. [CrossRef]

7. Han, J.; Peng, Y.; Lin, B.; Zhu, Y.; Ren, Z.; Xiao, L.; Zhuang, L. Hydrophobic Side-Chain Attached Polyarylether-Based Anion Exchange Membranes with Enhanced Alkaline Stability. ACS Appl. Energy Mater. 2019, 2, 8052-8059. [CrossRef]

8. Slonov, A.L.; Zhansitov, A.A.; Rzhevskaya, E.V.; Khakulova, D.M.; Sapaev, K.K.; Shetov, R.A.; Khashirova, S.Y. Influence of the Length and Concentration of Carbon and Glass Fibers on the Properties of Polyphenylene Sulfone. Fibre Chem. 2018, 50, 354-360. [CrossRef]

9. Liu, Y.; Yue, X.; Zhang, S.; Ren, J.; Yang, L.; Wang, Q.; Wang, G. Synthesis of sulfonated polyphenylsulfone as candidates for antifouling ultrafiltration membrane. Sep. Purif. Technol. 2012, 98, 298-307. [CrossRef]

10. Kiani, S.; Mousavi, S.M.; Saljoughi, E.; Shahtahmassebi, N. Preparation and characterization of modified polyphenylsulfone membranes with hydrophilic property for filtration of aqueous media. Polym. Adv. Technol. 2018, 29, 1632-1648. [CrossRef] 
11. Norrman, K.; Wang, Y.; Stamate, E.; Zhang, W. Controlling surface properties of electrospun polyphenylsulfone using plasma treatment and X-ray photoelectron spectroscopy. Heliyon 2019, 5, e01943. [CrossRef] [PubMed]

12. Han, J.; Liu, Q.; Li, X.; Pan, J.; Wei, L.; Wu, Y.; Peng, H.; Wang, Y.; Li, G.; Chen, C.; et al. An effective approach for alleviating cation-induced backbone degradation in aromatic ether-based alkaline polymer electrolytes. ACS Appl. Mater. Interfaces 2015, 7, 2809-2816. [CrossRef] [PubMed]

13. Yin, Q.; Zhang, Q.; Cui, Z.; Li, W.; Xing, W. Alkali resisting polyphenylsulfone ultrafiltration membrane with tailored microstructure. Polymer 2017, 124, 128-138. [CrossRef]

14. Darvishmanesh, S.; Jansen, J.C.; Tasselli, F.; Tocci, E.; Luis, P.; Degrève, J.; Drioli, E.; Van der Bruggen, B. Novel polyphenylsulfone membrane for potential use in solvent nanofiltration. J. Memb. Sci. 2011, 379, 60-68. [CrossRef]

15. Hong, S.H.; Cha, M.S.; Hong, S.-K.; Oh, S.-G.; Lee, J.Y. Structural Effect of the Hydrophobic Block on the Chemical Stability of Ion-Conducting Multiblock Copolymers for Flow Battery. ACS Sustain. Chem. Eng. 2019, 7, 17088-17099. [CrossRef]

16. Feng, Y.; Han, G.; Zhang, L.; Chen, S.B.; Chung, T.S.; Weber, M.; Staudt, C.; Maletzko, C. Rheology and phase inversion behavior of polyphenylenesulfone (PPSU) and sulfonated PPSU for membrane formation. Polymer 2016, 99, 72-82. [CrossRef]

17. Sadrzadeh, M.; Bhattacharjee, S. Rational design of phase inversion membranes by tailoring thermodynamics and kinetics of casting solution using polymer additives. J. Memb. Sci. 2013, 441, 31-44. [CrossRef]

18. Nadour, M.; Boukraa, F.; Benaboura, A. Removal of Diclofenac, Paracetamol and Metronidazole using a carbon-polymeric membrane. J. Environ. Chem. Eng. 2019, 7, 103080. [CrossRef]

19. Yang, Y.N.; Jun, W.; Zheng, Q.Z.; Cheng, X.S.; Zhang, H.X. The research of rheology and thermodynamics of organic-inorganic hybrid membrane during the membrane formation. J. Memb. Sci. 2008, 311, 200-207. [CrossRef]

20. Hwang, L.L.; Tseng, H.H.; Chen, J.C. Fabrication of polyphenylsulfone/polyetherimide blend membranes for ultrafiltration applications: The effects of blending ratio on membrane properties and humic acid removal performance. J. Memb. Sci. 2011, 384, 72-81. [CrossRef]

21. Feng, Y.; Han, G.; Chung, T.S.; Weber, M.; Widjojo, N.; Maletzko, C. Effects of polyethylene glycol on membrane formation and properties of hydrophilic sulfonated polyphenylenesulfone (sPPSU) membranes. J. Memb. Sci. 2017, 531, 27-35. [CrossRef]

22. Ballengee, J.B.; Pintauro, P.N. Composite Fuel Cell Membranes from Dual-Nanofiber Electrospun Mats. Macromolecules 2011, 44, 7307-7314. [CrossRef]

23. Zhang, Y.; Kim, J.D.; Miyatake, K. Effect of thermal crosslinking on the properties of sulfonated poly(phenylene sulfone)s as proton conductive membranes. J. Appl. Polym. Sci. 2016, 133. [CrossRef]

24. Feng, Y.; Liu, Q.; Lin, X.; Liu, J.Z.; Wang, H. Hydrophilic Nanowire Modified Polymer Ultrafiltration Membranes with High Water Flux. ACS Appl. Mater. Interfaces 2014, 6, 19161-19167. [CrossRef]

25. Chen, X.; Wang, W.; Zhu, L.; Liu, C.; Cui, F.; Li, N.; Zhang, B. Graphene Oxide/Polyamide-Based Nanofiltration Membranes for Water Purification. ACS Appl. Nano Mater. 2020, 4, 673-682. [CrossRef]

26. Li, S.; Liu, S.; Huang, F.; Lin, S.; Zhang, H.; Cao, S.; Chen, L.; He, Z.; Lutes, R.; Yang, J.; et al. Preparation and Characterization of Cellulose-Based Nanofiltration Membranes by Interfacial Polymerization with Piperazine and Trimesoyl Chloride. ACS Sustain. Chem. Eng. 2018, 6, 13168-13176. [CrossRef]

27. Liao, Z.; Fang, X.; Xie, J.; Li, Q.; Wang, D.; Sun, X.; Wang, L.; Li, J. Hydrophilic Hollow Nanocube-Functionalized Thin Film Nanocomposite Membrane with Enhanced Nanofiltration Performance. ACS Appl. Mater. Interfaces 2019, 11, 5344-5352. [CrossRef]

28. Xiao, S.; Yu, S.; Yan, L.; Liu, Y.; Tan, X. Preparation and properties of PPSU/GO mixed matrix membrane. Chin. J. Chem. Eng. 2017, 25, 408-414. [CrossRef]

29. Dorf, T.; Ferrer, I.; Ciurana, J. The effect of weld line on tensile strength of polyphenylsulfone (PPSU) in ultrasonic micro-moulding technology. Int. J. Adv. Manuf. Technol. 2019, 103, 2391-2400. [CrossRef]

30. Liu, J.; Zhong, Z.; Ma, R.; Zhang, W.; Li, J. Development of High-Antifouling PPSU Ultrafiltration Membrane by Using Compound Additives: Preparation, Morphologies, and Filtration Resistant Properties. Membranes 2016, 6, 35-49. [CrossRef] [PubMed]

31. Saranya, R.; Arthanareeswaran, G.; Ismail, A.F.; Reddy, N.L.; Shankar, M.V.; Kweon, J. Efficient rejection of organic compounds using functionalized ZSM-5 incorporated PPSU mixed matrix membrane. RSC Adv. 2017, 7, 15536-15552. [CrossRef]

32. Zhang, L.; Xu, J.; Tang, Y.; Hou, J.; Yu, L.; Gao, C. A novel long-lasting antifouling membrane modified with bifunctional capsaicin-mimic moieties: Via in situ polymerization for efficient water purification. J. Mater. Chem. A 2016, 4, 10352-10362 [CrossRef]

33. Liu, Y.; Su, Y.; Cao, J.; Guan, J.; Xu, L.; Zhang, R.; He, M.; Zhang, Q.; Fan, L.; Jiang, Z. Synergy of the mechanical, antifouling and permeation properties of a carbon nanotube nanohybrid membrane for efficient oil/water separation. Nanoscale 2017, 9 , 7508-7518. [CrossRef] [PubMed]

34. Daneshvar, H.; Seyed Dorraji, M.S.; Rasoulifard, M.H.; Ahmadi, A.; Nooshiran-Zadeh, N. Tris(hydroxymethyl)aminomethanegrafted polyamine nanofiltration membrane: Enhanced antifouling and pH resistant properties. New J. Chem. 2020, 44, 6321-6330. [CrossRef]

35. Ureña, N.; Pérez-Prior, M.T.; del Río, C.; Várez, A.; Sanchez, J.Y.; Iojoiu, C.; Levenfeld, B. Multiblock copolymers of sulfonated PSU/PPSU Poly(ether sulfone)s as solid electrolytes for proton exchange membrane fuel cells. Electrochim. Acta 2019, 302, 428-440. [CrossRef] 
36. Çalhan, A.; Deniz, S.; Kujawski, W.; Kujawa, J.; Knozowska, K.; Hasanoğlu, A. Silica Filled Polyphenylsulfone/Polydimethylsiloxane Composite Membranes for Pervaporation Separation of Biobutanol from ABE Mixtures. Chem. Eng. Process. Process Intensif. 2020, 156, 108099. [CrossRef]

37. Medalsy, I.D.; Müller, D.J. Nanomechanical Properties of Proteins and Membranes Depend on Loading Rate and Electrostatic Interactions. ACS Nano 2013, 7, 2642-2650. [CrossRef]

38. Rho, H.; Cho, J.; Westerhoff, P.; Chon, K. Intrinsic pKa of Nanofiltration Membrane Surfaces to Assess Fouling and Cleaning Behaviors Induced by Foulant-Membrane Electrostatic Interactions. Environ. Sci. Technol. 2020, 54, 7706-7714. [CrossRef]

39. Kobayashi, D.; Nakahara, H.; Shibata, O.; Unoura, K.; Nabika, H. Interplay of Hydrophobic and Electrostatic Interactions between Polyoxometalates and Lipid Molecules. J. Phys. Chem. C 2017, 121, 12895-12902. [CrossRef]

40. Rong, G.; Zhou, D.; Pang, J. Preparation of high-performance antifouling polyphenylsulfone ultrafiltration membrane by the addition of sulfonated polyaniline. J. Polym. Res. 2018, 25, 1-9. [CrossRef]

41. Shukla, A.K.; Alam, J.; Ansari, M.A.; Alhoshan, M.; Ali, F.A.A. Antimicrobial and antifouling properties of versatile PPSU/carboxylated GO nanocomposite membrane against Gram-positive and Gram-negative bacteria and protein. Environ. Sci. Pollut. Res. 2018, 25, 34103-34113. [CrossRef] [PubMed]

42. Nayak, M.C.; Isloor, A.M.; Moslehyani, A.; Ismail, A.F. Preparation and characterization of PPSU membranes with BiOCl nanowafers loaded on activated charcoal for oil in water separation. J. Taiwan Inst. Chem. Eng. 2017, 77, 293-301. [CrossRef]

43. Slonov, A.L.; Zhansitov, A.A.; Rzhevskaya, E.V.; Khakulova, D.M.; Sapaev, K.K.; Shetov, R.A.; Khashirova, S.Y. Effects of Length and Concentration of Carbon and Glass Fibers on Polyphenylene Sulfone Properties. Fibre Chem. 2019, 50, 402-407. [CrossRef]

44. Zhong, P.; Fu, X.; Chung, T.-S.; Weber, M.; Maletzko, C. Development of Thin-Film Composite forward Osmosis Hollow Fiber Membranes Using Direct Sulfonated Polyphenylenesulfone (sPPSU) as Membrane Substrates. Environ. Sci. Technol. 2013, 47, 7430-7436. [CrossRef] [PubMed]

45. Kumar, M.; Isloor, A.M.; Somasekhara Rao, T.; Ismail, A.F.; Farnood, R.; Nambissan, P.M.G. Removal of toxic arsenic from aqueous media using polyphenylsulfone/cellulose acetate hollow fiber membranes containing zirconium oxide. Chem. Eng. J. 2020, 393, 124367. [CrossRef]

46. Darvishmanesh, S.; Tasselli, F.; Jansen, J.C.; Tocci, E.; Bazzarelli, F.; Bernardo, P.; Luis, P.; Degrève, J.; Drioli, E.; Van der Bruggen, B. Preparation of solvent stable polyphenylsulfone hollow fiber nanofiltration membranes. J. Memb. Sci. 2011, 384, 89-96. [CrossRef]

47. Jaafer, M.J.; Al-Najar, J.A.; Alsalhy, Q.F. Poly(phenyl sulfone) hollow fiber forward osmosis membrane for saline water desalination. Chem. Eng. Process. Process Intensif. 2020, 157, 108119. [CrossRef]

48. Praneeth, K.; Suresh, K.B.; James, T.; Sridhar, S. Design of novel ultrafiltration systems based on robust polyphenylsulfone hollow fiber membranes for treatment of contaminated surface water. Chem. Eng. J. 2014, 248, 297-306.

49. Arumugham, T.; Kaleekkal, N.J.; Doraiswamy, M. Development of new hybrid ultrafiltration membranes by entanglement of macromolecular PPSU-SO3H chains: Preparation, morphologies, mechanical strength, and fouling resistant properties. J. Appl. Polym. Sci. 2015, 132, 1-9. [CrossRef]

50. Sgreccia, E.; Di Vona, M.L.; Knauth, P. Hybrid composite membranes based on SPEEK and functionalized PPSU for PEM fuel cells. Int. J. Hydrogen Energy 2011, 36, 8063-8069. [CrossRef]

51. Dyck, A.; Fritsch, D.; Nunes, S.P. Proton-conductive membranes of sulfonated polyphenylsulfone. J. Appl. Polym. Sci. 2002, 86, 2820-2827. [CrossRef]

52. Karlsson, L.E.; Jannasch, P. Polysulfone ionomers for proton-conducting fuel cell membranes: 2. Sulfophenylated polysulfones and polyphenylsulfones. Electrochim. Acta 2005, 50, 1939-1946. [CrossRef]

53. Ramiro, J.; Egulazábal, J.I.; Nazábal, J. New miscible poly(ether imide)/poly(phenyl sulfone) blends. Macromol. Mater. Eng. 2006, 291, 707-713. [CrossRef]

54. Di Vona, M.L.; D’Epifanio, A.; Marani, D.; Trombetta, M.; Traversa, E.; Licoccia, S. SPEEK/PPSU-based organic-inorganic membranes: Proton conducting electrolytes in anhydrous and wet environments. J. Memb. Sci. 2006, 279, 186-191. [CrossRef]

55. Licoccia, S.; Di Vona, M.L.; D’Epifanio, A.; Ahmed, Z.; Bellitto, S.; Marani, D.; Mecheri, B.; de Bonis, C.; Trombetta, M.; Traversa, E. SPPSU-based hybrid proton conducting polymeric electrolytes for intermediate temperature PEMFCs. J. Power Sources 2007, 167, 79-83. [CrossRef]

56. Weng, T.H.; Tseng, H.H.; Wey, M.Y. Preparation and characterization of PPSU/PBNPI blend membrane for hydrogen separation. Int. J. Hydrogen Energy 2008, 33, 4178-4182. [CrossRef]

57. Weng, T.H.; Tseng, H.H.; Wey, M.Y. Effects of crosslinking modification on the $\mathrm{O}_{2} / \mathrm{N}_{2}$ separation characteristics of poly(phenyl sulfone)/poly(bisphenol A-co-4-nitrophthalic anhydride-co-1,3-phenylenediamine) blend membranes. J. Appl. Polym. Sci. 2010, $116,1254-1263$.

58. Zhong, P.S.; Widjojo, N.; Chung, T.S.; Weber, M.; Maletzko, C. Positively charged nanofiltration (NF) membranes via UV grafting on sulfonated polyphenylenesulfone (sPPSU) for effective removal of textile dyes from wastewater. J. Memb. Sci. 2012, 417-418, 52-60. [CrossRef]

59. Liu, Y.; Zhang, S.; Zhou, Z.; Ren, J.; Geng, Z.; Luan, J.; Wang, G. Novel sulfonated thin-film composite nanofiltration membranes with improved water flux for treatment of dye solutions. J. Memb. Sci. 2012, 394-395, 218-229. [CrossRef]

60. Kim, J.D.; Donnadio, A.; Jun, M.S.; Di Vona, M.L. Crosslinked SPES-SPPSU membranes for high temperature PEMFCs. Int. J. Hydrogen Energy 2013, 38, 1517-1523. [CrossRef] 
61. Widjojo, N.; Chung, T.S.; Weber, M.; Maletzko, C.; Warzelhan, V. A sulfonated polyphenylenesulfone (sPPSU) as the supporting substrate in thin film composite (TFC) membranes with enhanced performance for forward osmosis (FO). Chem. Eng. J. 2013, 220, 15-23. [CrossRef]

62. Jansen, J.C.; Darvishmanesh, S.; Tasselli, F.; Bazzarelli, F.; Bernardo, P.; Tocci, E.; Friess, K.; Randova, A.; Drioli, E.; Van der Bruggen, B. Influence of the blend composition on the properties and separation performance of novel solvent resistant polyphenylsulfone/polyimide nanofiltration membranes. J. Memb. Sci. 2013, 447, 107-118. [CrossRef]

63. Díez-Pascual, A.M.; Díez-Vicente, A.L. Effect of $\mathrm{TiO}_{2}$ nanoparticles on the performance of polyphenylsulfone biomaterial for orthopaedic implants. J. Mater. Chem. B 2014, 2, 7502-7514. [CrossRef] [PubMed]

64. Zhang, B.; Zhang, E.; Wang, G.; Yu, P.; Zhao, Q.; Yao, F. Poly(phenyl sulfone) anion exchange membranes with pyridinium groups for vanadium redox flow battery applications. J. Power Sources 2015, 282, 328-334. [CrossRef]

65. Sani, N.A.A.; Lau, W.J.; Ismail, A.F. Polyphenylsulfone-based solvent resistant nanofiltration (SRNF) membrane incorporated with copper-1,3,5-benzenetricarboxylate (Cu-BTC) nanoparticles for methanol separation. RSC Adv. 2015, 5, 13000-13010. [CrossRef]

66. Kiani, S.; Mousavi, S.M.; Shahtahmassebi, N.; Saljoughi, E. Hydrophilicity improvement in polyphenylsulfone nanofibrous filtration membranes through addition of polyethylene glycol. Appl. Surf. Sci. 2015, 359, 252-258. [CrossRef]

67. Yong, W.F.; Lee, Z.K.; Chung, T.S. Blends of a polymer of intrinsic microporosity and partially sulfonated polyphenylenesulfone for Gas separation. ChemSusChem 2016, 9, 1953-1962. [CrossRef]

68. Saranya, R.; Kumar, M.; Tamilarasan, R.; Ismail, A.F.; Arthanareeswaran, G. Functionalised activated carbon modified polyphenylsulfone composite membranes for adsorption enhanced phenol filtration. J. Chem. Technol. Biotechnol. 2016, 91, 748-761. [CrossRef]

69. Arumugham, T.; Kaleekkal, N.J.; Rana, D.; Doraiswamy, M. Separation of oil/water emulsions using nano MgO anchored hybrid ultrafiltration membranes for environmental abatement. J. Appl. Polym. Sci. 2016, 133, 1-12. [CrossRef]

70. Sani, N.A.A.; Lau, W.J.; Nordin, N.A.H.M.; Ismail, A.F. Influence of organic solvents and operating conditions on the performance of polyphenylsulfone (PPSU)/copper-1,3,5-benzenetricarboxylate (Cu-BTC) solvent resistant nanofiltration (SRNF) membranes. Chem. Eng. Res. Des. 2016, 115, 66-76. [CrossRef]

71. Kim, J.D.; Ghil, L.J. Annealing effect of highly sulfonated polyphenylsulfone polymer. Int. J. Hydrogen Energy 2016, 41, 11794-11800. [CrossRef]

72. Yam-Cervantes, M.A.; Santiago-García, J.L.; Loría-Bastarrachea, M.I.; Duarte-Aranda, S.; Alberto Ruiz-Treviño, F.; Aguilar-Vega, M. Sulfonated polyphenylsulfone asymmetric membranes: Effect of coagulation bath (acetic acid- $\mathrm{NaHCO}_{3} /$ isopropanol) on morphology and antifouling properties. J. Appl. Polym. Sci. 2017, 134, 44502. [CrossRef]

73. Zhao, N.; Liu, T.; Liu, Z.; Su, Y.; Yu, H.; Ma, J.; Yang, Y.; Jiang, Z. Synthesis and properties of sulfonated biphenyl poly(ether sulfone) and its mixed-matrix membranes containing carbon nanotubes for gas separation. J. Appl. Polym. Sci. 2017, 134, 44995. [CrossRef]

74. Alam, J.; Alhoshan, M.; Shukla, A.K.; Aldalbahi, A.; Ali, F.A.A.; Dass, L.A.; Muthumareeswaran, M.R. k-Carrageenan as a promising pore-former for the preparation of a highly porous polyphenylsulfone membrane. Mater. Lett. 2017, 204, 108-111. [CrossRef]

75. Mahmoudian, M.; Balkanloo, P.G. Clay-hyperbranched epoxy/polyphenylsulfone nanocomposite membranes. Iran. Polym. J. 2017, 26, 711-720. [CrossRef]

76. Golpour, M.; Pakizeh, M. Development of a new nanofiltration membrane for removal of kinetic hydrate inhibitor from water. Sep. Purif. Technol. 2017, 183, 237-248. [CrossRef]

77. Lawrence Arockiasamy, D.; Alhoshan, M.; Alam, J.; Muthumareeswaran, M.R.; Figoli, A.; Arun Kumar, S. Separation of proteins and antifouling properties of polyphenylsulfone based mixed matrix hollow fiber membranes. Sep. Purif. Technol. 2017, 174, 529-543. [CrossRef]

78. Plisko, T.V.; Bildyukevich, A.V.; Karslyan, Y.A.; Ovcharova, A.A.; Volkov, V.V. Development of high flux ultrafiltration polyphenylsulfone membranes applying the systems with upper and lower critical solution temperatures: Effect of polyethylene glycol molecular weight and coagulation bath temperature. J. Memb. Sci. 2018, 565, 266-280. [CrossRef]

79. Asadi Tashvigh, A.; Luo, L.; Chung, T.S.; Weber, M.; Maletzko, C. A novel ionically cross-linked sulfonated polyphenylsulfone (sPPSU) membrane for organic solvent nanofiltration (OSN). J. Memb. Sci. 2018, 545, 221-228. [CrossRef]

80. Bildyukevich, A.V.; Plisko, T.V.; Isaichykova, Y.A.; Ovcharova, A.A. Preparation of High-Flux Ultrafiltration Polyphenylsulfone Membranes. Pet. Chem. 2018, 58, 747-759. [CrossRef]

81. Golpour, M.; Pakizeh, M. Preparation and characterization of new PA-MOF/PPSU-GO membrane for the separation of KHI from water. Chem. Eng. J. 2018, 345, 221-232. [CrossRef]

82. Asadi Tashvigh, A.; Luo, L.; Chung, T.S.; Weber, M.; Maletzko, C. Performance enhancement in organic solvent nanofiltration by double crosslinking technique using sulfonated polyphenylsulfone (sPPSU) and polybenzimidazole (PBI). J. Memb. Sci. 2018, 551, 204-213. [CrossRef]

83. Naderi, A.; Asadi Tashvigh, A.; Chung, T.S.; Weber, M.; Maletzko, C. Molecular design of double crosslinked sulfonated polyphenylsulfone / polybenzimidazole blend membranes for an efficient hydrogen purification. J. Memb. Sci. 2018, 563, 726-733. [CrossRef]

84. Arumugham, T.; Kaleekkal, N.J.; Rana, D. Fabrication of novel aromatic amine functionalized nanofiltration (NF) membranes and testing its dye removal and desalting ability. Polym. Test. 2018, 72, 1-10. [CrossRef] 
85. Shukla, A.K.; Alam, J.; Alhoshan, M.; Dass, L.A.; Ali, F.A.A.; Muthumareeswaran, M.R.; Mishra, U.; Ansari, M.A. Removal of heavy metal ions using a carboxylated graphene oxide-incorporated polyphenylsulfone nanofiltration membrane. Environ. Sci. Water Res. Technol. 2018, 4, 438-448. [CrossRef]

86. Moideen, I.K.; Isloor, A.M.; Qaiser, A.A.; Ismail, A.F.; Abdullah, M.S. Separation of heavy metal and protein from wastewater by sulfonated polyphenylsulfone ultrafiltration membrane process prepared by glycine betaine enriched coagulation bath. Korean $J$. Chem. Eng. 2018, 35, 1281-1289. [CrossRef]

87. Shukla, A.K.; Alam, J.; Ansari, M.A.; Alhoshan, M.; Alam, M.; Kaushik, A. Selective ion removal and antibacterial activity of silverdoped multi-walled carbon nanotube/polyphenylsulfone nanocomposite membranes. Mater. Chem. Phys. 2019, 233, 102-112. [CrossRef]

88. Shi, M.; Liu, L.; Tong, Y.; Huang, L.; Li, W.; Xing, W. Advanced porous polyphenylsulfone membrane with ultrahigh chemical stability and selectivity for vanadium flow batteries. J. Appl. Polym. Sci. 2019, 136, 47752. [CrossRef]

89. Nayak, M.C.; Isloor, A.M.; Prabhu, B.; Norafiqah, N.I.; Asiri, A.M. Novel polyphenylsulfone (PPSU)/nano tin oxide $\left(\mathrm{SnO}_{2}\right) \mathrm{mixed}$ matrix ultrafiltration hollow fiber membranes: Fabrication, characterization and toxic dyes removal from aqueous solutions. React. Funct. Polym. 2019, 139, 170-180.

90. Arumugham, T.; Amimodu, R.G.; Kaleekkal, N.J.; Rana, D. Nano CuO/g- $\mathrm{C}_{3} \mathrm{~N}_{4}$ sheets-based ultrafiltration membrane with enhanced interfacial affinity, antifouling and protein separation performances for water treatment application. J. Environ. Sci. 2019, 82, 57-69. [CrossRef]

91. Wang, Y.; Górecki, R.P.; Stamate, E.; Norrman, K.; Aili, D.; Zuo, M.; Guo, W.; Hélix-Nielsen, C.; Zhang, W. Preparation of super-hydrophilic polyphenylsulfone nanofiber membranes for water treatment. RSC Adv. 2019, 9, 278-286. [CrossRef]

92. Kumar, M.; Rao, T.S.; Isloor, A.M.; Ibrahim, G.P.S.; Ismail, N.; Ismail, A.F.; Asiri, A.M. Use of cellulose acetate/polyphenylsulfone derivatives to fabricate ultrafiltration hollow fiber membranes for the removal of arsenic from drinking water. Int. J. Biol. Macromol. 2019, 129, 715-727. [CrossRef] [PubMed]

93. Anwar, F.; Arthanareeswaran, G. Silver nano-particle coated hydroxyapatite nano-composite membrane for the treatment of palm oil mill effluent. J. Water Process Eng. 2019, 31, 100844. [CrossRef]

94. Chandrashekhar Nayak, M.; Isloor, A.M.; Lakshmi, B.; Marwani, H.M.; Khan, I. Polyphenylsulfone/multiwalled carbon nanotubes mixed ultrafiltration membranes: Fabrication, characterization and removal of heavy metals $\mathrm{Pb}^{2+}, \mathrm{Hg}^{2+}$, and $\mathrm{Cd}^{2+}$ from aqueous solutions. Arab. J. Chem. 2019, 13, 4661-4672. [CrossRef]

95. Shukla, A.K.; Alam, J.; Ali, F.A.A.; Alhoshan, M. Efficient soluble anionic dye removal and antimicrobial properties of ZnO embedded-polyphenylsulfone membrane. Water Environ. J. 2021, 35, 670-684. [CrossRef]

96. Gronwald, O.; Frost, I.; Ulbricht, M.; Kouchaki Shalmani, A.; Panglisch, S.; Grünig, L.; Handge, U.A.; Abetz, V.; Heijnen, M.; Weber, M. Hydrophilic poly(phenylene sulfone) membranes for ultrafiltration. Sep. Purif. Technol. 2020, 250, 117107. [CrossRef]

97. Dehban, A.; Kargari, A.; Ashtiani, F.Z. Preparation and optimization of antifouling PPSU/PES/SiO 2 nanocomposite ultrafiltration membranes by VIPS-NIPS technique. J. Ind. Eng. Chem. 2020, 88, 292-311. [CrossRef]

98. Vijesh, A.M.; Arathi Krishnan, P.V.; Isloor, A.M.; Shyma, P.C. Fabrication of PPSU/PANI hollow fiber membranes for humic acid removal. Mater. Today Proc. 2020, 41, 541-548. [CrossRef]

99. Mohamad Nor, N.A.; Nakao, H.; Jaafar, J.; Kim, J.D. Crosslinked carbon nanodots with highly sulfonated polyphenylsulfone as proton exchange membrane for fuel cell applications. Int. J. Hydrogen Energy 2020, 45, 9979-9988. [CrossRef]

100. Xiao, S.; Huo, X.; Fan, S.; Zhao, K.; Yu, S.; Tan, X. Design and synthesis of Al-MOF/PPSU mixed matrix membrane with pollution resistance. Chin. J. Chem. Eng. 2020, 29, 110-120. [CrossRef]

101. Kumar, M.; Isloor, A.M.; Todeti, S.R.; Ibrahim, G.P.S.; Ismail, A.F.; Asiri, A.M. Improved separation of dyes and proteins using membranes made of polyphenylsulfone/cellulose acetate or acetate phthalate. Environ. Chem. Lett. 2020, 18, 881-887. [CrossRef]

102. Shukla, A.K.; Alam, J.; Ali, F.A.A.; Alhoshan, M. A highly permeable zinc-based MOF/polyphenylsulfone composite membrane with elevated antifouling properties. Chem. Commun. 2020, 56, 5231-5234. [CrossRef] [PubMed]

103. Kumar, M.; Isloor, A.M.; Todeti, S.R.; Nagaraja, H.S.; Ismail, A.F.; Susanti, R. Effect of binary zinc-magnesium oxides on polyphenylsulfone/cellulose acetate derivatives hollow fiber membranes for the decontamination of arsenic from drinking water. Chem. Eng. J. 2021, 405, 126809. [CrossRef]

104. Alam, J.; Shukla, A.K.; Ansari, M.A.; Abdulraqeb, F.; Ali, A.; Alhoshan, M. Dye Separation and Antibacterial Activities of Polyaniline Thin Film-Coated Poly (phenyl sulfone) Membranes. Membranes 2021, 11, 25-40. [CrossRef]

105. Jutemar, E.P.; Takamuku, S.; Jannasch, P. Sulfonated poly(arylene ether sulfone) ionomers containing di- and tetrasulfonated arylene sulfone segments. Polym. Chem. 2011, 2, 181-191. [CrossRef]

106. Chen, R.; Li, G. New sulfonated poly(arylene ether sulfone) copolymers containing phenyl side chains as proton exchange membranes. New J. Chem. 2016, 40, 3755-3762. [CrossRef]

107. Tang, Y.; Chen, C.; Ye, Y.S.; Xue, Z.; Zhou, X.; Xie, X. The enhanced actuation response of an ionic polymer-metal composite actuator based on sulfonated polyphenylsulfone. Polym. Chem. 2014, 5, 6097-6107. [CrossRef]

108. Nor, N.A.M.; Jaafar, J.; Kim, J.D. Improved properties of sulfonated octaphenyl polyhedral silsequioxane cross-link with highly sulfonated polyphenylsulfone as proton exchange membrane. J. Solid State Electrochem. 2020, 24, 1185-1195. [CrossRef]

109. Yoshida-Hirahara, M.; Takahashi, S.; Yoshizawa-Fujita, M.; Takeoka, Y.; Rikukawa, M. Synthesis and investigation of sulfonated poly( $p$-phenylene)-based ionomers with precisely controlled ion exchange capacity for use as polymer electrolyte membranes. RSC Adv. 2020, 10, 12810-12822. [CrossRef] 
110. Luo, L.; Han, G.; Chung, T.S.; Weber, M.; Staudt, C.; Maletzko, C. Oil/water separation via ultrafiltration by novel triangle-shape tri-bore hollow fiber membranes from sulfonated polyphenylenesulfone. J. Memb. Sci. 2015, 476, 162-170. [CrossRef]

111. Tang, Y.; Widjojo, N.; Shi, G.M.; Chung, T.S.; Weber, M.; Maletzko, C. Development of flat-sheet membranes for C1-C4 alcohols dehydration via pervaporation from sulfonated polyphenylsulfone (sPPSU). J. Memb. Sci. 2012, 415-416, 686-695. [CrossRef]

112. Hartmann-Thompson, C.; Merrington, A.; Carver, P.I.; Keeley, D.L.; Rousseau, J.L.; Hucul, D.; Bruza, K.J.; Thomas, L.S.; Keinath, S.E.; Nowak, R.M.; et al. Proton-conducting polyhedral oligosilsesquioxane nanoadditives for sulfonated polyphenylsulfone hydrogen fuel cell proton exchange membranes. J. Appl. Polym. Sci. 2008, 110, 958-974. [CrossRef]

113. Di Vona, M.L.; Luchetti, L.; Spera, G.P.; Sgreccia, E.; Knauth, P. Synthetic strategies for the preparation of proton-conducting hybrid polymers based on PEEK and PPSU for PEM fuel cells. Comptes Rendus Chim. 2008, 11, 1074-1081. [CrossRef]

114. Jo, Y.J.; Choi, E.Y.; Kim, S.W.; Kim, C.K. Fabrication and characterization of a novel polyethersulfone/aminated polyethersulfone ultrafiltration membrane assembled with zinc oxide nanoparticles. Polymer 2016, 87, 290-299. [CrossRef]

115. Jyothi, M.S.; Nayak, V.; Padaki, M.; Geetha Balakrishna, R.; Soontarapa, K. Aminated polysulfone/ $\mathrm{TiO}_{2}$ composite membranes for an effective removal of $\mathrm{Cr}(\mathrm{VI})$. Chem. Eng. J. 2016, 283, 1494-1505. [CrossRef]

116. Serbanescu, O.S.; Voicu, S.I.; Thakur, V.K. Polysulfone functionalized membranes: Properties and challenges. Mater. Today Chem. 2020, 17, 100302. [CrossRef]

117. Dizman, C.; Altinkok, C.; Tasdelen, M.A. Synthesis of self-curable polysulfone containing pendant benzoxazine units via CuAAC click chemistry. Des. Monomers Polym. 2017, 20, 293-299. [CrossRef]

118. Di Vona, M.L.; Narducci, R.; Pasquini, L.; Pelzer, K.; Knauth, P. Anion-conducting ionomers: Study of type of functionalizing amine and macromolecular cross-linking. Int. J. Hydrogen Energy 2014, 39, 14039-14049. [CrossRef]

119. Sarath, C.C.; Shanks, R.A.; Thomas, S. Chapter 1-Polymer Blends. In Nanostructured Polymer Blends; Thomas, S., Shanks, R., Chandrasekharakurup, S., Eds.; William Andrew Publishing: Oxford, UK, 2014; pp. 1-14, ISBN 978-1-4557-3159-6.

120. Sabzi, F. Chapter 24-Gas Transport Through Polymer Blends. In Transport Properties of Polymeric Membranes; Thomas, S., Wilson, R., Kumar, S.A., George, S.C., Eds.; Elsevier: Amsterdam, The Netherlands, 2018; pp. 517-532, ISBN 978-0-12-809884-4.

121. Utracki, L.A. Polymer blends: Fundamentals. In Polypropylene; Karger-Kocsis, J., Ed.; Springer: Dordrecht, The Netherlands, 1999; pp. 601-605, ISBN 978-94-011-4421-6.

122. Ryan, A.J. Designer polymer blends. Nat. Mater. 2002, 1, 8-10. [CrossRef]

123. Yong, W.F.; Zhang, H. Recent advances in polymer blend membranes for gas separation and pervaporation. Prog. Mater. Sci. 2021, 116, 100713. [CrossRef]

124. Feng, S.; Kondo, S.; Kaseyama, T.; Nakazawa, T.; Kikuchi, T.; Selyanchyn, R.; Fujikawa, S.; Christiani, L.; Sasaki, K.; Nishihara, M. Development of polymer-polymer type charge-transfer blend membranes for fuel cell application. J. Memb. Sci. 2018, 548, $223-231$. [CrossRef]

125. Niaounakis, M. Chapter 3-Blending. In Biopolymers: Processing and Products; Niaounakis, M., Ed.; William Andrew Publishing: Oxford, UK, 2015; pp. 117-185, ISBN 978-0-323-26698-7.

126. Rajeswari, A.; Stobel Christy, E.J.; Pius, A. Chapter 5-Biopolymer blends and composites: Processing technologies and their properties for industrial applications. In Biopolymers and Their Industrial Applications; Thomas, S., Gopi, S., Amalraj, A., Eds.; Elsevier: Amsterdam, The Netherlands, 2021; pp. 105-147, ISBN 978-0-12-819240-5.

127. Heeres, H.J.; van Maastrigt, F.; Picchioni, F. Polymeric Blends with Biopolymers. In Handbook of Biopolymer-Based Materials: From Blends and Composites to Gels and Complex Networks; Wiley-VCH Verlag GmbH \& Co. KGaA: New York, NY, USA, 2013; pp. 143-171, ISBN 9783527328840.

128. Robeson, L.M. Polymer Blends in Membrane Transport Processes. Ind. Eng. Chem. Res. 2010, 49, 11859-11865. [CrossRef]

129. Islam, M.S.; Islam, M.M. 2-Physical and chemical properties of sustainable polymers and their blends. In Advances in Sustainable Polymer Composites; Rahman, M.R., Ed.; Woodhead Publishing: Cambridge, UK, 2021; pp. 37-57, ISBN 978-0-12-820338-5.

130. García, M.G.; Marchese, J.; Ochoa, N.A. Aliphatic-aromatic polyimide blends for $\mathrm{H}_{2}$ separation. Int. J. Hydrogen Energy 2010, 35, 8983-8992. [CrossRef]

131. Jones, P.J.; Paslay, L.C.; Morgan, S.E. Effects of chain conformation on miscibility, morphology, and mechanical properties of solution blended substituted polyphenylene and polyphenylsulfone. Polymer 2010, 51, 738-747. [CrossRef]

132. White, J.L.; Wachowicz, M. Chapter 7 Polymer Blend Miscibility. In Annual Reports on nmR Spectroscopy; Webb, G.A., Ed.; Academic Press: Cambridge, MA, USA, 2008; Volume 64, pp. 189-209, ISBN 0066-4103.

133. Goh, S.H. Miscible Polymer Blends. In Polymer Blends Handbook; Utracki, L.A., Wilkie, C.A., Eds.; Springer: Dordrecht, The Netherlands, 2014; pp. 1915-2151, ISBN 978-94-007-6064-6.

134. Rana, D.; Bag, K.; Bhattacharyya, S.N.; Mandal, B.M. Miscibility of poly(styrene-co-butyl acrylate) with poly(ethyl methacrylate): Existence of both UCST and LCST. J. Polym. Sci. Part B Polym. Phys. 2000, 38, 369-375. [CrossRef]

135. Olabisi, O. Interpretations of polymer-polymer miscibility. J. Chem. Educ. 1981, 58, 944-950. [CrossRef]

136. Arrighi, V.; Cowie, J.M.G.; Fuhrmann, S.; Youssef, A. Miscibility Criterion in Polymer Blends and its Determination. Encycl. Polym. Blends 2010, 1, 153-198. [CrossRef]

137. Higgins, J.S.; Lipson, J.E.G.; White, R.P. A simple approach to polymer mixture miscibility. Philos. Trans. R. Soc. A Math. Phys. Eng. Sci. 2010, 368, 1009-1025. [CrossRef]

138. Hopfenberg, H.B.; Paul, D.R. Chapter 10-Transport Phenomena in Polymer Blends. In Polymer Blends; Paul, D.R., Newman, S., Eds.; Academic Press: Cambridge, MA, USA, 1978; pp. 445-489, ISBN 978-0-12-546801-5. 
139. Fu, Z.; Wang, H.; Zhao, X.; Horiuchi, S.; Li, Y. Immiscible polymer blends compatibilized with reactive hybrid nanoparticles: Morphologies and properties. Polymer 2017, 132, 353-361. [CrossRef]

140. Abtal, E.; Prud'Homme, R.E. Orientation of miscible and immiscible polymer blends. Polym. Eng. Sci. 1992, 32, 1857-1862. [CrossRef]

141. Alkhodairi, H.; Russell, S.T.; Pribyl, J.; Benicewicz, B.C.; Kumar, S.K. Compatibilizing Immiscible Polymer Blends with Sparsely Grafted Nanoparticles. Macromolecules 2020, 53, 10330-10338. [CrossRef]

142. Marischal, L.; Cayla, A.; Lemort, G.; Campagne, C.; Éric, D. Selection of immiscible polymer blends filled with carbon nanotubes for heating applications. Polymers 2019, 11, 1827. [CrossRef]

143. Aseeri, J.; Alandis, N.M.; Mekhamer, W.; Alam, M. Miscibility studies of polystyrene/polyvinyl chloride blend in presence of organoclay. Open Chem. 2019, 17, 927-935. [CrossRef]

144. Ajitha, A.R.; Thomas, S. Chapter 1-Introduction: Polymer blends, thermodynamics, miscibility, phase separation, and compatibilization. In Compatibilization of Polymer Blends; Ajitha, A.R., Thomas, S., Eds.; Elsevier: Amsterdam, The Netherlands, 2020; pp. 1-29, ISBN 978-0-12-816006-0.

145. Kordjazi, Z.; Ajji, A. Partially miscible polymer blends of ethyl cellulose and hydroxyl terminated polybutadiene. Polymer 2020, 211, 123067. [CrossRef]

146. Pan, P.; Bao, J.; Han, L.; Xie, Q.; Shan, G.; Bao, Y. Stereocomplexation of high-molecular-weight enantiomeric poly(lactic acid)s enhanced by miscible polymer blending with hydrogen bond interactions. Polymer 2016, 98, 80-87. [CrossRef]

147. Kiani, S.; Mousavi, S.M.; Saljoughi, E.; Shahtahmassebi, N. Preparation of amorphous polyphenylsulfone nanofiltration membrane via thermally-induced lamination. J. Non. Cryst. Solids 2021, 551, 120416. [CrossRef]

148. Kiani, S.; Mousavi, S.M.; Saljoughi, E.; Shahtahmassebi, N. Novel high flux nanofibrous composite membrane based on polyphenylsulfone thin barrier layer on nanofibrous support. Fibers Polym. 2017, 18, 1531-1544. [CrossRef]

149. Kiani, S.; Mousavi, S.M.; Shahtahmassebi, N.; Saljoughi, E. Preparation and characterization of polyphenylsulfone nanofibrous membranes for the potential use in liquid filtration. Desalin. Water Treat. 2016, 57, 16250-16259. [CrossRef]

150. Jones, P.J.; Cook, R.D.; McWright, C.N.; Nalty, R.J.; Choudhary, V.; Morgan, S.E. Polyhedral oligomeric silsesquioxanepolyphenylsulfone nanocomposites: Investigation of the melt-flow enhancement, thermal behavior, and mechanical properties. J. Appl. Polym. Sci. 2011, 121, 2945-2956. [CrossRef]

151. Shukla, A.K.; Alam, J.; Rahaman, M.; Alrehaili, A.; Alhoshan, M.; Aldalbahi, A. A Facile Approach for Elimination of Electroneutral/Anionic Organic Dyes from Water Using a Developed Carbon-Based Polymer Nanocomposite Membrane. Water. Air. Soil Pollut. 2020, 231, 104-119. [CrossRef]

152. Shukla, A.K.; Alam, J.; Alhoshan, M.; Dass, L.A.; Muthumareeswaran, M.R. Development of a nanocomposite ultrafiltration membrane based on polyphenylsulfone blended with graphene oxide. Sci. Rep. 2017, 7, 41976-41987. [CrossRef]

153. Sani, N.A.A.; Lau, W.J.; Ismail, A.F. Morphologies and separation characteristics of polyphenylsulfone-based solvent resistant nanofiltration membranes: Effect of polymer concentration in casting solution and membrane pretreatment condition. Korean $J$. Chem. Eng. 2015, 32, 743-752. [CrossRef]

154. Ali, Q.; Taweepreda, W.; Techato, K. Preparation and characterization of polymer electrolyte membrane from chloroacetate chitosan/chitosan blended with epoxidized natural rubber. Polym. Test. 2020, 82, 106294. [CrossRef]

155. Imre, B.; Pukánszky, B. Compatibilization in bio-based and biodegradable polymer blends. Eur. Polym. J. 2013, 49, 1215-1233. [CrossRef]

156. Galiano, F.; Briceño, K.; Marino, T.; Molino, A.; Christensen, K.V.; Figoli, A. Advances in biopolymer-based membrane preparation and applications. J. Memb. Sci. 2018, 564, 562-586. [CrossRef]

157. Sivakanthan, S.; Rajendran, S.; Gamage, A.; Madhujith, T.; Mani, S. Antioxidant and antimicrobial applications of biopolymers: A review. Food Res. Int. 2020, 136, 109327. [CrossRef]

158. Sun, F.Y.; Wang, X.M.; Li, X.Y. Effect of biopolymer clusters on the fouling property of sludge from a membrane bioreactor (MBR) and its control by ozonation. Process Biochem. 2011, 46, 162-167. [CrossRef]

159. Qin, Y.; Yang, H.; Xu, Z.; Li, F. Surface Modification of Polyacrylonitrile Membrane by Chemical Reaction and Physical Coating: Comparison between Static and Pore-Flowing Procedures. ACS Omega 2018, 3, 4231-4241. [CrossRef]

160. Lau, W.-J.; Ong, C.-S.; Nordin, N.A.H.M.; Sani, N.A.A.; Mokhtar, N.M.; Jamshidi Gohari, R.; Emadzadeh, D.; Fauzi Ismail, A. Surface Modification of Polymeric Membranes for Various Separation Processes. Surf. Treat. Biol. Chem. Phys. Appl. 2017, 34, 115-180.

161. Jullok, N.; Darvishmanesh, S.; Luis, P.; Van der Bruggen, B. The potential of pervaporation for separation of acetic acid and water mixtures using polyphenylsulfone membranes. Chem. Eng. J. 2011, 175, 306-315. [CrossRef]

162. Mys, N.; Geiregat, M.; Deruyck, F.; Verberckmoes, A.; Cardon, L. Physicochemical processing of polyphenylsulfone: Optimization of processing parameters for microsphere production via spray drying using a response surface model. Adv. Polym. Technol. 2018, 37, 3747-3758. [CrossRef]

163. Lu, Z.; Dunn, M.L. Van der Waals adhesion of graphene membranes. J. Appl. Phys. 2010, 107, 44301. [CrossRef]

164. Israelachvili, J.N. Chapter 13-Van der Waals Forces between Particles and Surfaces. In Intermolecular and Surface Forces, 3rd ed.; Israelachvili, J.N., Ed.; Academic Press: San Diego, CA, USA, 2011; pp. 253-289, ISBN 978-0-12-375182-9. 
165. He, M.; Fan, X.; Yang, Z.; Zhang, R.; Liu, Y.; Fan, L.; Zhang, Q.; Su, Y.; Jiang, Z. Antifouling high-flux membranes via surface segregation and phase separation controlled by the synergy of hydrophobic and hydrogen bond interactions. J. Memb. Sci. 2016, 520, 814-822. [CrossRef]

166. Alayemieka, E.; Lee, S.; Lee, S.; Kim, D. A power-law model of electrostatic interactions of colloidal particles in cake layer on membrane surface. Desalination 2010, 250, 793-797. [CrossRef]

167. Li, Q.; Shi, W.; Yang, Q. Polarization Induced Covalent Bonding: A New Force of Heavy Metal Adsorption on Charged Particle Surface. J. Hazard. Mater. 2021, 412, 125168. [CrossRef] [PubMed]

168. Ding, J.; Cui, Z.; Dong, N.; Li, B.; Zhang, Y.; Wang, J.; Jiang, Z. Enhanced optical limiting properties of composite films consisting of hyperbranched phthalocyanine and polyphenylsulfone with high linear transmittance. Synth. Met. 2020, 265, 116405. [CrossRef]

169. Cui, Z.; Zhang, H.; Li, B.; Jiang, Z.; Zhang, Y.; Li, Z. New Type of Eco-Friendly Polymeric Dye by Covalently Bonding Anthraquinone into Polyphenylsulfone. Macromol. Mater. Eng. 2019, 304, 1-9. [CrossRef]

170. Ahmadi, Y.; Moeini, N.; Yadav, M.; Ahmad, S. Chapter 12-Antimicrobial polymer nanocomposite films and coatings. In Handbook of Polymer Nanocomposites for Industrial Applications; Hussain, C.M., Ed.; Elsevier: Amsterdam, The Netherlands, 2021; pp. 379-397, ISBN 978-0-12-821497-8.

171. Reis, R.; Dumée, L.F.; Tardy, B.L.; Dagastine, R.; Orbell, J.D.; Schutz, J.A.; Duke, M.C. Towards Enhanced Performance Thin-film Composite Membranes via Surface Plasma Modification. Sci. Rep. 2016, 6, 29206. [CrossRef]

172. Puppolo, M.M.; Hughey, J.R.; Weber, B.; Dillon, T.; Storey, D.; Cerkez, E.; Jansen-Varnum, S. Plasma modification of microporous polymer membranes for application in biomimetic dissolution studies. AAPS Open 2017, 3, 1-13. [CrossRef]

173. Wavhal, D.S.; Fisher, E.R. Membrane Surface Modification by Plasma-Induced Polymerization of Acrylamide for Improved Surface Properties and Reduced Protein Fouling. Langmuir 2003, 19, 79-85. [CrossRef]

174. Kormunda, M.; Ryšánek, P.; Hájková, P.; Štěpanovská, E.; Čapková, P.; Pavlík, J. Effect of low energy plasma treatment on surface chemistry and phase composition of electrospun polyvinylidene fluoride membrane. Surf. Interfaces 2021, 22, 100900. [CrossRef]

175. Al-Jumaili, A.; Alancherry, S.; Grant, D.; Kumar, A.; Bazaka, K.; Jacob, M.V. Chapter 8-Plasma Treatment of Polymeric Membranes. In Non-Thermal Plasma Technology for Polymeric Materials; Thomas, S., Mozetič, M., Cvelbar, U., Špatenka, P., Praveen, K.M., Eds.; Elsevier: Amsterdam, The Netherlands, 2019; pp. 211-240, ISBN 978-0-12-813152-7.

176. Fatyeyeva, K.; Dahi, A.; Chappey, C.; Langevin, D.; Valleton, J.M.; Poncin-Epaillard, F.; Marais, S. Effect of cold plasma treatment on surface properties and gas permeability of polyimide films. RSC Adv. 2014, 4, 31036-31046. [CrossRef]

177. Poncin-Epaillard, F.; Brosse, J.C.; Falher, T. Cold Plasma Treatment: Surface or Bulk Modification of Polymer Films? Macromolecules 1997, 30, 4415-4420. [CrossRef]

178. Yang, Q.; Hu, M.-X.; Dai, Z.-W.; Tian, J.; Xu, Z.-K. Fabrication of Glycosylated Surface on Polymer Membrane by UV-Induced Graft Polymerization for Lectin Recognition. Langmuir 2006, 22, 9345-9349. [CrossRef] [PubMed]

179. Dai, J.; Li, S.; Liu, J.; He, J.; Li, J.; Wang, L.; Lei, J. Fabrication and characterization of a defect-free mixed matrix membrane by facile mixing PPSU with ZIF-8 core-shell microspheres for solvent-resistant nanofiltration. J. Memb. Sci. 2019, 589, 117261. [CrossRef]

180. Gohil, J.M.; Ray, P. A review on semi-aromatic polyamide TFC membranes prepared by interfacial polymerization: Potential for water treatment and desalination. Sep. Purif. Technol. 2017, 181, 159-182. [CrossRef]

181. Shukla, A.K.; Alam, J.; Alhoshan, M.S.; Ali, F.A.A.; Mishra, U.; Hamid, A.A. Thin-Film Nanocomposite Membrane Incorporated with Porous Zn-Based Metal-Organic Frameworks: Toward Enhancement of Desalination Performance and Chlorine Resistance. ACS Appl. Mater. Interfaces 2021, 13, 28818-28831. [CrossRef] 